\title{
Photovoltaics Business Models
}

Subcontract Report NREL/SR-581-42304

February 2008

L. Frantzis, S. Graham, R. Katofsky, and $\mathrm{H}$. Sawyer Navigant Consulting Inc. Burlington, Massachusetts

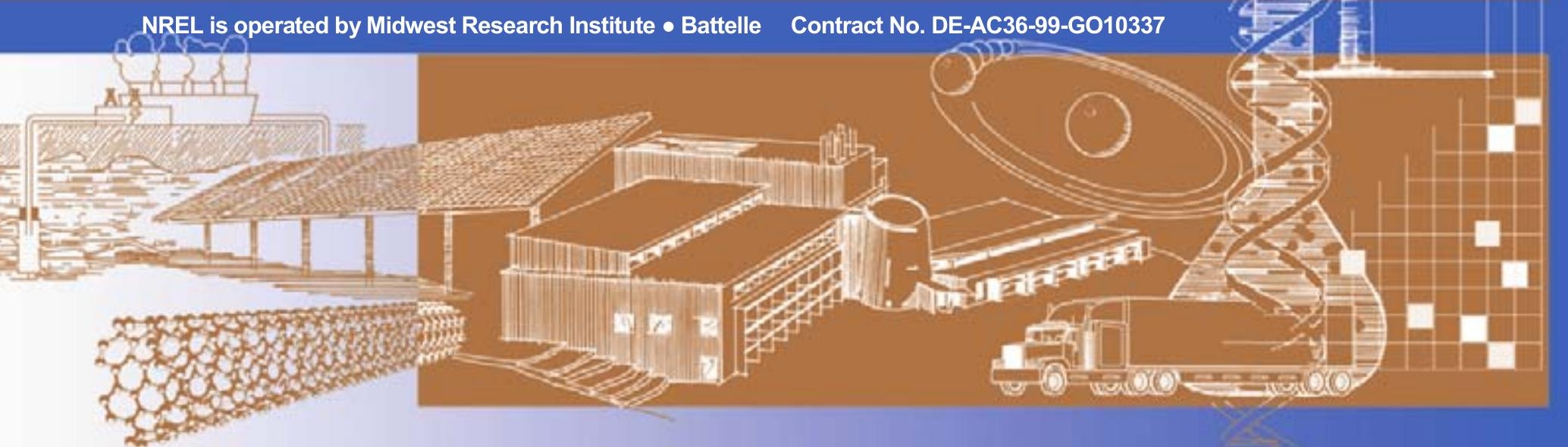




\section{Photovoltaics Business Models}

Subcontract Report NREL/SR-581-42304

February 2008

L. Frantzis, S. Graham, R. Katofsky, and H. Sawyer Navigant Consulting Inc.

Burlington, Massachusetts

NREL Technical Monitor: Robert Margolis

Prepared under Subcontract No. KACX-4-44451-08

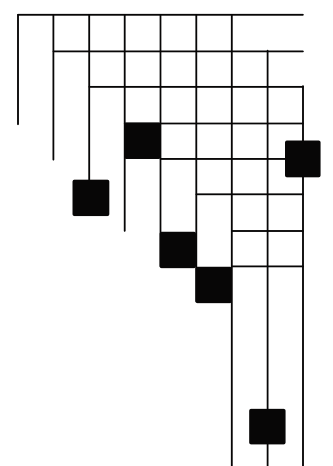




\section{NOTICE}

This report was prepared as an account of work sponsored by an agency of the United States government. Neither the United States government nor any agency thereof, nor any of their employees, makes any warranty, express or implied, or assumes any legal liability or responsibility for the accuracy, completeness, or usefulness of any information, apparatus, product, or process disclosed, or represents that its use would not infringe privately owned rights. Reference herein to any specific commercial product, process, or service by trade name, trademark, manufacturer, or otherwise does not necessarily constitute or imply its endorsement, recommendation, or favoring by the United States government or any agency thereof. The views and opinions of authors expressed herein do not necessarily state or reflect those of the United States government or any agency thereof.

Available electronically at http://www.osti.gov/bridge

Available for a processing fee to U.S. Department of Energy and its contractors, in paper, from:

U.S. Department of Energy

Office of Scientific and Technical Information

P.O. Box 62

Oak Ridge, TN 37831-0062

phone: 865.576 .8401

fax: 865.576 .5728

email: mailto:reports@adonis.osti.gov

Available for sale to the public, in paper, from:

U.S. Department of Commerce

National Technical Information Service

5285 Port Royal Road

Springfield, VA 22161

phone: 800.553 .6847

fax: 703.605.6900

email: orders@ntis.fedworld.gov

online ordering: http://www.ntis.gov/ordering.htm

This publication received minimal editorial review at NREL 


\section{Preface}

Now is the time to plan for the integration of significant quantities of distributed renewable energy into the electricity grid. Concerns about climate change, the adoption of state-level renewable portfolio standards and incentives, and accelerated cost reductions are driving steep growth in U.S. renewable energy technologies. The number of distributed solar photovoltaic (PV) installations, in particular, is growing rapidly. As distributed PV and other renewable energy technologies mature, they can provide a significant share of our nation's electricity demand. However, as their market share grows, concerns about potential impacts on the stability and operation of the electricity grid may create barriers to their future expansion.

To facilitate more extensive adoption of renewable distributed electric generation, the U.S. Department of Energy launched the Renewable Systems Interconnection (RSI) study during the spring of 2007. This study addresses the technical and analytical challenges that must be addressed to enable high penetration levels of distributed renewable energy technologies. Because integration-related issues at the distribution system are likely to emerge first for PV technology, the RSI study focuses on this area. A key goal of the RSI study is to identify the research and development needed to build the foundation for a high-penetration renewable energy future while enhancing the operation of the electricity grid.

The RSI study consists of 15 reports that address a variety of issues related to distributed systems technology development; advanced distribution systems integration; systemlevel tests and demonstrations; technical and market analysis; resource assessment; and codes, standards, and regulatory implementation. The RSI reports are:

- Renewable Systems Interconnection: Executive Summary

- Distributed Photovoltaic Systems Design and Technology Requirements

- Advanced Grid Planning and Operation

- Utility Models, Analysis, and Simulation Tools

- Cyber Security Analysis

- Power System Planning: Emerging Practices Suitable for Evaluating the Impact of High-Penetration Photovoltaics

- Distribution System Voltage Performance Analysis for High-Penetration Photovoltaics

- Enhanced Reliability of Photovoltaic Systems with Energy Storage and Controls

- Transmission System Performance Analysis for High-Penetration Photovoltaics

- Solar Resource Assessment

- Test and Demonstration Program Definition

- Photovoltaics Value Analysis 
- Photovoltaics Business Models

- Production Cost Modeling for High Levels of Photovoltaic Penetration

- Rooftop Photovoltaics Market Penetration Scenarios.

Addressing grid-integration issues is a necessary prerequisite for the long-term viability of the distributed renewable energy industry, in general, and the distributed PV industry, in particular. The RSI study is one step on this path. The Department of Energy is also working with stakeholders to develop a research and development plan aimed at making this vision a reality. 


\section{Acknowledgments}

The authors would like to thank the Department of Energy (DOE) and the National Renewable Energy Laboratory (NREL) for supporting our work on this topic and the industry experts who provided input including Robert Margolis, Peter H. Kobos, Dan Rastler, and Mark Bolinger. We would also like to thank reviewers at all of the companies who took time to review the case studies and examples presented in this document, including staff from (in alphabetical order): Arizona Public Service, Austin Energy, Borrego Solar, NSTAR, Old Country Roofing, SDG\&E, the Sacramento Municipal Utility District (SMUD), SunEdison, SunPower, Xcel Energy, and We Energies.

We would also like to thank our colleagues at Navigant Consulting Inc. who provided valuable input, including Craig McDonald and Stan Blazewicz.

In addition, we would like to acknowledge that in our informal conversations with industry on the topic of future business models, we confronted a great spectrum of opinions regarding how things will unfold; in particular, this was true for utility involvement. Some industry leaders thought that utility involvement in distributed PV will remain limited, while others view utility involvement, including control and ownership, as inevitable. This report examines the spectrum of options for the future. 


\section{Executive Summary}

As photovoltaics (PV) demonstrate the potential to significantly penetrate the electric generation market, a question arises: How might government action encourage business models that promote the development of PV?

This report is a first structured, comprehensive, and public attempt to answer that question. Our investigation identified several key findings:

- The question is dynamic, and has broad implications for a wide array of stakeholders - most notably utilities.

- While the number of installed distributed PV systems will eventually become a material and operational concern — or opportunity - for utilities, the full benefits of an extensive distributed PV resource are not likely to be realized without some degree of utility control and possibly ownership.

- Who owns and controls the PV facilities and the related flows of cash and other benefits is key to determining the potential viability of any PV business model.

- It appears that key industry stakeholders have considered changes to current models of ownership and control, but few have moved forward, indicating that barriers, such as the current regulatory structure, insufficient scale, and other priorities, impede optimum development.

- Smart-grid technologies are expected to be very important for the emerging PV business models. While this report does not focus on specific recommendations, it is clear that the ongoing RD\&D in this area, both public and private, will be critical for distributed PV. Similarly, distributed PV may become an important enabler for deployment of these technologies, as higher levels of PV market penetration necessitate their use.

- Each potential future business model identified in this report has several permutations, and it is not yet clear which is likely to be the most successful, how multiple business models could co-exist, or if one may evolve into another over time. Attempting to pilot any particular one at this time appears to be premature.

- The scale of a potential pilot program involving utilities feeds back into the advisability of delaying the implementation of a pilot until a greater level of stakeholder engagement is achieved in the preliminary assessment.

- It appears to be a question of when, and not if, there will be a need for new PV business models, in order to accommodate and facilitate widespread adoption of distributed PV. 


\section{Background}

Current PV business models principally revolve around the ownership of PV systems by individuals and increasingly by third parties, rather than by utilities. At today's low levels of market penetration, distributed, grid-connected PV is not a central concern nor even of great interest to most utilities. However, as PV market penetration accelerates, utilities will become critical stakeholders, driven primarily by concerns about grid operation, safety, and revenue erosion.

Until now, utilities have mainly responded to regulators who asked of them nothing more than to help customers who wanted to purchase or acquire a PV system. In the process, some utilities have removed key barriers to PV deployment to a limited extent, mainly by providing net metering and adopting simplified, standardized interconnection standards and agreements. In addition, regulators have sometimes obligated utilities to purchase renewable energy certificates (RECs) generated by PV owners, particularly in states with specific mandates for solar energy.

On the whole, however, the utility's role in the PV market has been passive. PV has not been a core utility business endeavor nor a concern, primarily because 1) the cost of PV has exceeded that of other energy delivery options, and 2) utilities have seen, up to the present, no clear business/regulatory model that will allow them to recover high distributed PV costs.

\section{Project Scope and Objectives}

The objectives of the study presented here are to:

- Document current and emerging PV business models,

- Identify a range of potential future business models that enhance the value of PV to key stakeholders and thus increase market penetration (e.g., by incorporating energy storage, controls, and other technologies which allow the system to be independently controlled and dispatchable), and

- Discuss how promising potential future business models might be encouraged in the marketplace by government action, including DOE-sponsored research, development, and deployment (RD\&D).

The basic premise explored in this report is that large amounts of distributed PV create a new paradigm that has the potential to radically alter a utility's business model. Of all stakeholders involved, it is the utility that will have its existing business model most disrupted as the PV market expands. However, it is also the utility that has the potential to best utilize the unique, quantifiable benefits of the electricity generated by a PV system.

\section{Overview of PV Business Model Evolution}

The PV industry is moving away from the early approach in which the customer not only owned and financed the PV system, but also managed most aspects of installation. This approach is referred to as the Zero Generation PV business model; its attractiveness was 
limited to a relatively small group of so-called pioneers ${ }^{1}$ who were committed to PV's environmental, energy security, and self-generation benefits. The PV industry has evolved to 1st Generation PV business models, in which the product is more attractive to a broader market, moving into the so-called early adopter customer category ${ }^{2}$ (See Figure ES-1-1).

$2^{\text {nd }}$ Generation business models have yet to emerge, but will emphasize greater integration of the PV systems into the grid because emerging technologies and regulatory initiatives are likely to make such integration more viable and valuable. $2^{\text {nd }}$ Generation business models are the focus of the future business models explored in this report, as they are expected to become increasingly important to various stakeholders.

\begin{tabular}{|c|c|}
\hline \multicolumn{2}{|c|}{ Evolution of PV Business Mo } \\
\hline $\begin{array}{l}0 \text { Generation } \\
\text { PV System Supply }\end{array}$ & $\begin{array}{l}\text { Third-Party Ownership \& } \\
\text { Operation }\end{array}$ \\
\hline $\begin{array}{l}\text { - Business models focus on } \\
\text { manufacturing, supply and } \\
\text { installation of PV systems } \\
\text { - End-user is the owner } \\
\text { - Utility is largely passive, } \\
\text { providing net metering and } \\
\text { standard/simplified } \\
\text { interconnection, but } \\
\text { otherwise, unaffected. }\end{array}$ & $\begin{array}{l}\text { - Business models driven by } \\
\text { third parties which develop } \\
\text { projects and own PV } \\
\text { systems, resulting in: } \\
\text { - Reduction of hassle \& } \\
\text { complexity for end-user } \\
\text { - Better access to financing } \\
\text { - Leveraging of current } \\
\text { incentives structure } \\
\text { (especially for } \\
\text { commercial building } \\
\text { applications) }\end{array}$ \\
\hline & $\begin{array}{l}\text { - Utility gradually takes on a } \\
\text { facilitation role as PV } \\
\text { market share grows }\end{array}$ \\
\hline
\end{tabular}

Figure ES-1-1. Evolution of PV business models

Although the utility to date has been generally reactive to state requirements (e.g., net metering, standardized interconnection), it is expected to become proactive in the distributed PV market as it is pushed to key stakeholder status. Once PV reaches significant market penetration (perhaps $10-15 \%$ of a utility's peak load), utility involvement will be driven by concerns for grid infrastructure, safety, and of course, revenue erosion. An appropriate business model can promote and accelerate the utility's willing promulgation of PV and help unlock its full value.

\footnotetext{
${ }^{1}$ Geoffrey Moore, Crossing the Chasm, Harper Business, 1991.

${ }^{2}$ Id.
} 


\section{Current PV Business Models}

In the PV marketplace today, numerous interesting developments are occurring within the confines of the existing regulatory framework and utility business structure. The growing PV industry is developing new, more efficient ways to deliver products, services, and financing to customers while also addressing key market barriers. Improvements and innovations being made by the PV industry to Zero and $1^{\text {st }}$ Generation business models are very important and are a prerequisite for the industry to achieve a higher level of maturity and scale. The ongoing PV activity within these Zero and $1^{\text {st }}$ Generation business models will help bring the industry down the cost curve and up the market penetration curve, implying more availability of PV to the grid in general.

Digging deeper into how PV business models are characterized, we defined the marketplace for this study using the aspects of 1) ownership and 2) application. These two aspects were chosen for the following reasons. First, changes to system ownership have been and are expected to be a key driver of additional market growth. Second, current business models vary significantly by the application, as much of the focus of Zero and $1^{\text {st }}$ Generation business models is on the supply chain and getting product, financing and related services to customers in more effective ways. Figure ES-1-2 identifies the key current ownership-application models and their relative level of development in the market.

\begin{tabular}{|c|c|c|c|c|}
\hline \multicolumn{5}{|c|}{ Leading PV Ownership-Application Models Today } \\
\hline \multirow{2}{*}{\multicolumn{2}{|c|}{ Application }} & \multicolumn{3}{|c|}{ Ownership } \\
\hline & & \multirow{2}{*}{$\begin{array}{c}\text { End-User } \\
\end{array}$} & \multirow{2}{*}{$\begin{array}{c}3^{\text {rd }} \text { Party } \\
\text { Minimal } \\
\text { activity }\end{array}$} & \multirow{3}{*}{$\begin{array}{l}\text { Utility } \\
\text { Minimal } \\
\text { activity }\end{array}$} \\
\hline \multirow{2}{*}{ Residential } & Retrofit & & & \\
\hline & New Construction & O & $\begin{array}{l}\text { Minimal } \\
\text { activity }\end{array}$ & \\
\hline \multirow{2}{*}{ Commercial } & Retrofit & 0 & $\odot$ & \multirow{2}{*}{$\begin{array}{l}\text { Minimal } \\
\text { activity }\end{array}$} \\
\hline & New Construction & $\begin{array}{l}\text { Minimal } \\
\text { activity }\end{array}$ & $\begin{array}{c}\text { Minimal } \\
\text { activity }\end{array}$ & \\
\hline \multicolumn{2}{|c|}{ Grid-sited (utility side of meter) } & NA & O & $\begin{array}{c}\text { Minimal } \\
\text { activity }\end{array}$ \\
\hline
\end{tabular}

Figure ES-1-2. Leading PV Ownership-Application models today

By characterizing the current marketplace using the ownership and application framework, several things become apparent:

- The dominant ownership model has been end-user owned, 0 Generation, models.

- The dominant applications have been both commercial and residential retrofit, not new construction or grid-sited. 
- Today third-party ownership is quickly becoming an established ownership approach for commercial applications, and is also emerging as an ownership approach for grid-sited applications. This is moving the marketplace into the $1^{\text {st }}$ Generation PV business model discussed above.

- Utility ownership of distributed PV has been minimal, as viable business models have been lacking. $2^{\text {nd }}$ Generation models have yet to really take hold.

Each type of five key ownership-application models in Figure ES-1-2 is described graphically in the full report using a value network to show the relationships and the value transferred between key stakeholders. An example of a value network is shown in Figure ES-1-3 for the end-user owned residential retrofit application to describe the most basic approach. Variations to the basic ownership-application models are also provided in the full report, as they provide insight into where innovation is occurring in the marketplace and can be largely correlated with industry trends, such as: reduction of hassle and complexity, product supply chain efficiency, and reduction of financing cost.

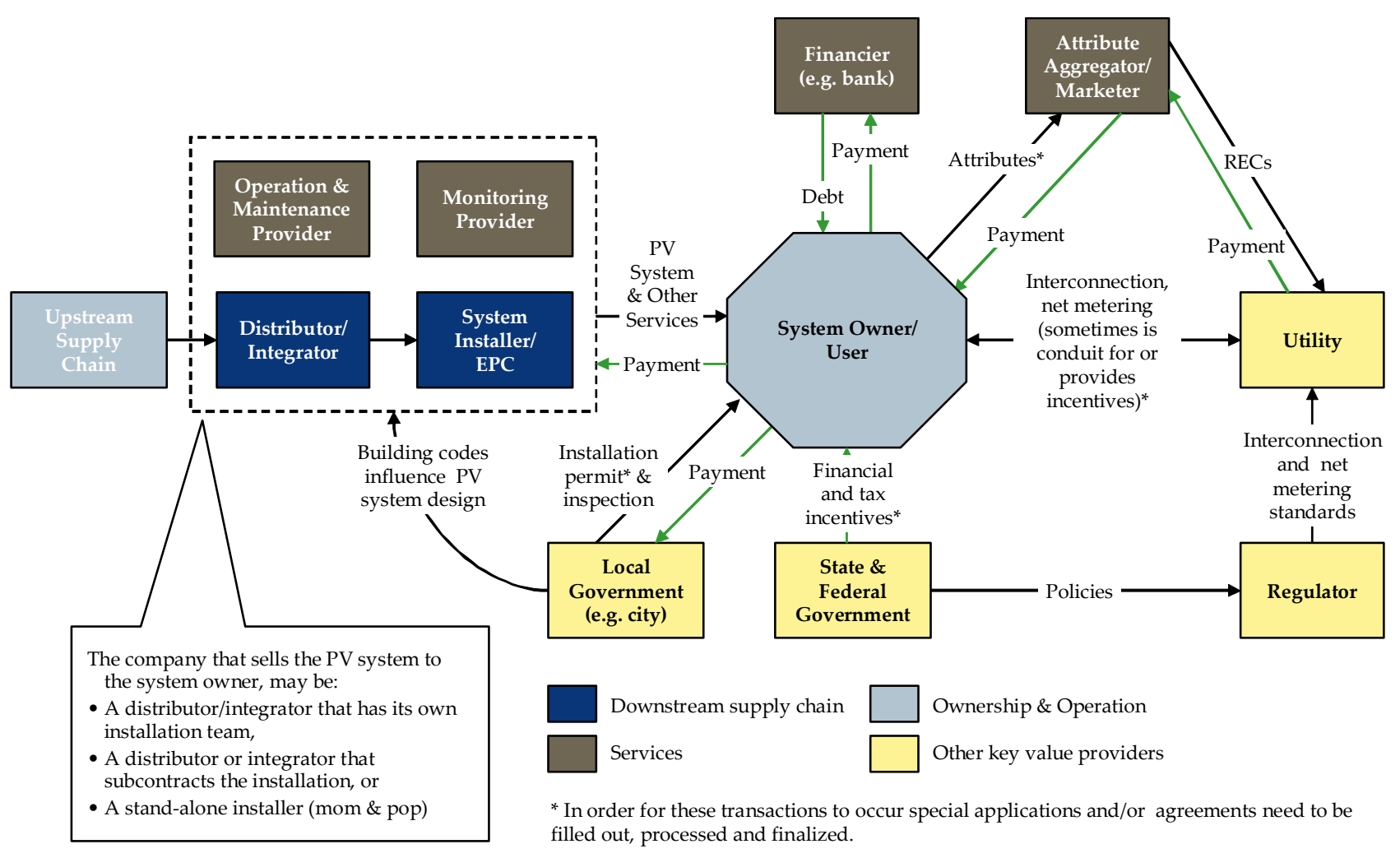

Figure ES-1-3. Example of Value Network: End-user Owned Residential Retrofit ${ }^{3}$

\footnotetext{
${ }^{3} \mathrm{EPC}=$ Engineer, Procure, Construct
} 
The diagrams of the business models were useful in the study when considering how relationships and flow of values between key stakeholders would change in the future due to the emergence of new business models.

As this study progressed, it became apparent that the ownership attribute remained a key factor in defining future business models, but that the characteristic of application was not critical. Instead the question of who controls the PV system became a defining factor of future business models, thus, future business models are characterized in this report by ownership and control. As discussed in the future business models section below, we assume that as the PV supply chain matures the application (e.g., where the system is installed) will become less important than who controls the system and how.

\section{Current Utility Involvement in PV Business Models}

As discussed above, utilities do not currently generally own PV system. However, utilities are involved in the current PV business models in ways that are important when considering what they might do in the future. Historically, utility participation in the PV market was limited to a few cases of retailing PV systems and providing system rebates, especially by municipal utilities. However, a growing number of investor-owned utilities have recently taken on more active roles in PV markets. Using our taxonomy of PV business model evolution, this type of utility activity falls under $1^{\text {st }}$ Generation utility facilitation of PV business models. This activity is seen as supporting other business models, not as a stand-alone business model. Table ES-1 below provides a brief description of current initiatives that utilities have created to facilitate the development of PV.

Table ES-1. Examples of Utility Programs Supporting Current PV Business Models

\begin{tabular}{|l|l|l|}
\hline \hline Program & Utility & Brief Description \\
\hline Financing & APS & $\begin{array}{l}\text { Building a structure through which banks and lenders offer special } \\
\text { financing or refinancing to solar customers (e.g., APS pays the PV } \\
\text { rebate directly to the lender and the incentive is used to buy down the } \\
\text { interest rate or to re-amortize the loan). }\end{array}$ \\
\hline Financing & PSE\&G & $\begin{array}{l}\text { Proposing to lend capital to end-users and solar developers for 40-50\% } \\
\text { of the project cost, which is repaid over 15 years with S-RECs, at a rate } \\
\text { of 12.11\%. S-RECs are valued at their floor price or current market price, } \\
\text { whichever is higher. }\end{array}$ \\
\hline $\begin{array}{l}\text { Technology } \\
\text { Partnership }\end{array}$ & NSTAR & $\begin{array}{l}\text { Aligning with Evergreen Solar to lower the overall cost of solar } \\
\text { generation by promoting standardized systems installed by pre-approved } \\
\text { solar contractors. }\end{array}$ \\
\hline $\begin{array}{l}\text { REC } \\
\text { Database }\end{array}$ & Xcel Energy & $\begin{array}{l}\text { Partnering with Pioneer Solutions to develop a software application to } \\
\text { view and track RECs for compliance and trading purposes. }\end{array}$ \\
\hline $\begin{array}{l}\text { Feed-in } \\
\text { Rate }\end{array}$ & We Energies & $\begin{array}{l}\text { Offering a feed-in tariff of 22.5 } \phi / k W h \text {. Eligible PV systems must be } \\
\text { between 1.5kW and 100kW, and customers must enroll for a 10-year } \\
\text { contract. }\end{array}$ \\
\hline
\end{tabular}


In addition to utility programs that support current business models, there are a few existing cases of utility ownership that could pave the way for greater involvement in distributed PV and a more active role either in ownership or control of PV systems (Table ES-2). This type of activity falls into our definition of $2^{\text {nd }}$ Generation business models as they include aspects of utility ownership.

Table ES-2. Examples of Utility PV Ownership

\begin{tabular}{|l|l|l|}
\hline Program & Utility & Brief Description \\
\hline $\begin{array}{l}\text { Customer- } \\
\text { sited PV }\end{array}$ & SDG\&E & $\begin{array}{l}\text { As part of its sustainable communities program, the utility is installing PV } \\
\text { systems at customer-sites on the utility side of the meter. Program was } \\
\text { approved by regulators and SDG\&E has \$4.3 million per year. SDG\&E is } \\
\text { working with LEED certifying body so that utility's PV systems can help } \\
\text { the building owner achieve LEED status. }\end{array}$ \\
\hline $\begin{array}{l}\text { Solar } \\
\text { Shares }\end{array}$ & SMUD & $\begin{array}{l}\text { SMUD is developing a grid-sited 1MW PV system which would allow } \\
\text { ratepayers to buy "shares" in it through a surcharge on monthly electric } \\
\text { bills. The program aims to attract homeowners or commercial customers } \\
\text { that want solar, but cannot install it because they rent, have shading } \\
\text { issues, or do not have access to up-front capital. }\end{array}$ \\
\hline $\begin{array}{l}\text { Services } \\
\text { Agreement } \\
\text { (with } \\
\text { ownership } \\
\text { option) }\end{array}$ & Austin Energy & $\begin{array}{l}\text { Considering a program to lease land to project developers. The } \\
\text { developer would build a PV or concentrating solar system and then } \\
\text { utilize/monetize the tax benefits, perhaps benefiting from Austin's access } \\
\text { to low cost tax-exempt debt, after which the developer may have the } \\
\text { option to transfer the ownership to Austin Energy. Additionally, Austin } \\
\text { Energy is considering prepayment options as well as possible lease } \\
\text { arrangements. }\end{array}$ \\
\hline
\end{tabular}

\section{Context for Future Business Models}

At the same time that the PV industry is making great strides in the deployment of PV using 0 and $1^{\text {st }}$ Generation approaches, significant activities are also occurring outside of the PV industry that have clear implications for long-term PV market penetration. In particular, changes in policy, technology, and utility regulation may hold the potential to not only create opportunities to unlock additional value from PV systems, but may simultaneously create more demand for it (see Figure ES-1-4).

Technology developments underway to manage the distribution grid more effectively will have many benefits for distributed generation, including PV. In particular, the development of distribution system automation, the transition to "smart grids," and the deployment of customer- and utility-controlled demand response are all likely to help utilities and others unlock additional value from distributed PV systems.

Policy trends that create a market for renewable energy, such as renewable portfolio standards or RPS (especially those with solar set-asides) and greenhouse gas emission caps, are gaining momentum at the state and local levels, and may ultimately culminate in much higher average state targets and, eventually, a federal-level policy.

Finally, regulatory changes in some states are altering the way a utility perceives its business. Beyond net metering and interconnection issues, performance-based ratemaking 
(in which incentive benchmarks, rather than budgets, determine cost recovery) and revenue decoupling mechanisms (in which rates are determined as a function of service delivery rather than as a strict return on hard assets) are being implemented to encourage energy efficiency, conservation, and renewable energy. Given these types of changes, the ability of a utility to realize revenue from rates that are based in part on reconfiguring its grid and altering its customer support to integrate PV will have obvious benefits for the further increase of distributed PV. In addition, some utilities have experimented with tariff structures to encourage desired consumer behaviors and the deployment of new technologies. For example, variations of time-of-use pricing can be very beneficial to PV economics. Also, adoption of transmission congestion pricing should have a beneficial impact on distributed PV, as the market value of distributed generation will be made plain by the congestion prices. These regulatory actions are increasingly being driven by the desire to encourage conservation or greenhouse gas reductions.

\begin{tabular}{|l|}
\hline \multicolumn{1}{|c|}{ Technology } \\
\hline - Development and \\
deployment of distribution \\
automation technologies \\
- Transition to "smart grids" \\
- Continued development and \\
deployment of other \\
distributed generation \\
technologies \\
- Development and \\
deployment of plug-in hybrid \\
vehicles (implications for grid \\
operations, load growth and \\
battery technology \\
development)
\end{tabular}

\begin{tabular}{|l|}
\hline \multicolumn{1}{|c|}{ Policy } \\
\hline - Further development of \\
Renewable portfolio \\
standards (increasingly with \\
solar set asides) \\
- Greenhouse gas emission cap \\
\& trade programs and other \\
climate change initiatives \\
- State-level economic \\
development initiatives \\
- Growth of state solar energy \\
initiatives and system \\
benefits charge funds
\end{tabular}

\begin{tabular}{|l|}
\hline \multicolumn{1}{|c|}{ Regulatory } \\
\hline - Performance-based \\
ratemaking \\
- Revenue decoupling to \\
encourage energy efficiency \\
and conservation \\
- Tariff structures optimized \\
for PV and other distributed \\
generation \\
- Demand response programs \\
(customer and utility \\
controlled) \\
\end{tabular}

Figure ES-1-4. External factors with implications for PV market development

Looking forward 10 to 20 years, there is a strong case to be made that PV in distributed applications, primarily customer-sited, will become an inevitable and significant component of the electricity sector, and especially if forecasted PV cost reductions materialize. In the long-term vision presented in this report, PV will pass a "tipping point" beyond which it is competitive with retail power supplied by the grid. The point of wide-scale competitiveness with grid power may come sooner as a result of specific breakthroughs in technology, or later as a result of the steady march down the cost curve. In either case, this vision depends on the PV supply chain being able to ramp up capacity to meet market demand.

When PV achieves a high degree of market penetration, there will be significant implications for key stakeholders, especially for the utility. PV will eventually be an operational problem for the utility if it is not strategically managed. Additionally, as the cost of PV comes down, distributed PV generation could become a competitive threat to central-station generation. 
Of all the stakeholders involved, it is the utility that will have its existing business model disrupted the most, and must therefore adapt to protect and enhance its business. Thus, greater utility involvement is seen as the key to future PV business models. In contemplating PV system ownership and control on the distribution grid, a utility can leverage what it already does well, including asset management and investment, customer service, and system operations (see Table ES-3).

For the utility, PV could simply become another rate-based asset to own, manage, and operate to provide equal or higher quality of service than what it provides today. In addition, PV may allow a utility to take maximum advantage of the capabilities that distribution automation and smart grid technologies will provide. In fact, PV arguably has the potential to be one of the most significant distributed resources managed by these technologies.

Table ES-3. Implications of Widespread Distributed PV Deployment on Key Stakeholders

\begin{tabular}{|c|c|}
\hline Stakeholder & Implications \\
\hline End-user & $\begin{array}{l}\text { PV system: } \\
\text { - Cost-effective alternative to the grid } \\
\text { - } \quad \text { Helps meet environmental desires of consumers } \\
\text { - Generates a range of value streams (driven in part by environmental } \\
\text { - } \text { and climate change policy) } \\
\text { end of a bundle of new technologies to improve energy service at } \\
\text { distribution system automation, "smart homes", plug-in hybrid } \\
\text { vehicles) }\end{array}$ \\
\hline System Owner & $\begin{array}{l}\text { - PV system output has multiple value streams that can make it } \\
\text { competitive in the market relative to grid power } \\
\text { - Owner needs to be able to identify and capture multiple PV value } \\
\text { streams }\end{array}$ \\
\hline $\begin{array}{l}\text { Distribution } \\
\text { Utility and } \\
\text { Vertically } \\
\text { Integrated } \\
\text { Utility }\end{array}$ & $\begin{array}{l}\text { - High degree of PV market penetration creates: } \\
\circ \quad \text { Reduced throughput leading to revenue loss under traditional } \\
\text { tariff structures } \\
\circ \quad \text { Need for control of PV systems and/or new distribution } \\
\text { system architectures to ensure safety, operational integrity, } \\
\text { and reliability of the distribution grid } \\
\text { - In addition, new technologies used in conjunction with PV could } \\
\text { radically change utility operations and product/service offerings to } \\
\text { customers (low-cost energy storage, distribution system automation, } \\
\text { "smart homes", plug-in hybrid vehicles) }\end{array}$ \\
\hline $\begin{array}{l}\text { Wholesale } \\
\text { Generator }\end{array}$ & $\begin{array}{l}\text { - High degree of PV market penetration could provide competition in the } \\
\text { wholesale market to more expensive generating assets }\end{array}$ \\
\hline Regulator & $\begin{array}{l}\text { - Emergence of cost-effective PV and other complementary technologies } \\
\text { creates need for major transformation of how utility industry is regulated }\end{array}$ \\
\hline $\begin{array}{l}\text { Transmission } \\
\text { Company }\end{array}$ & $\begin{array}{l}\text { - High degree of PV market penetration could impact the demand for } \\
\text { transmission services }\end{array}$ \\
\hline
\end{tabular}




\section{Future Business Models}

Three basic types of business models were identified in this report, as illustrated in Figure ES-1-5. The main distinctions among them lie in who owns and controls the PV system (a fourth option, in which the PV system is owned by the utility but not controlled by it, is not viewed as being a viable business model because the utility is unlikely to cede control of an asset that it owns). As will be discussed in more detail below, the success of any of these three business models will be tightly linked to ongoing technology and market developments in distribution automation and demand response, and may also require significant regulatory changes. In the full report, variations of each basic type of business models are discussed.

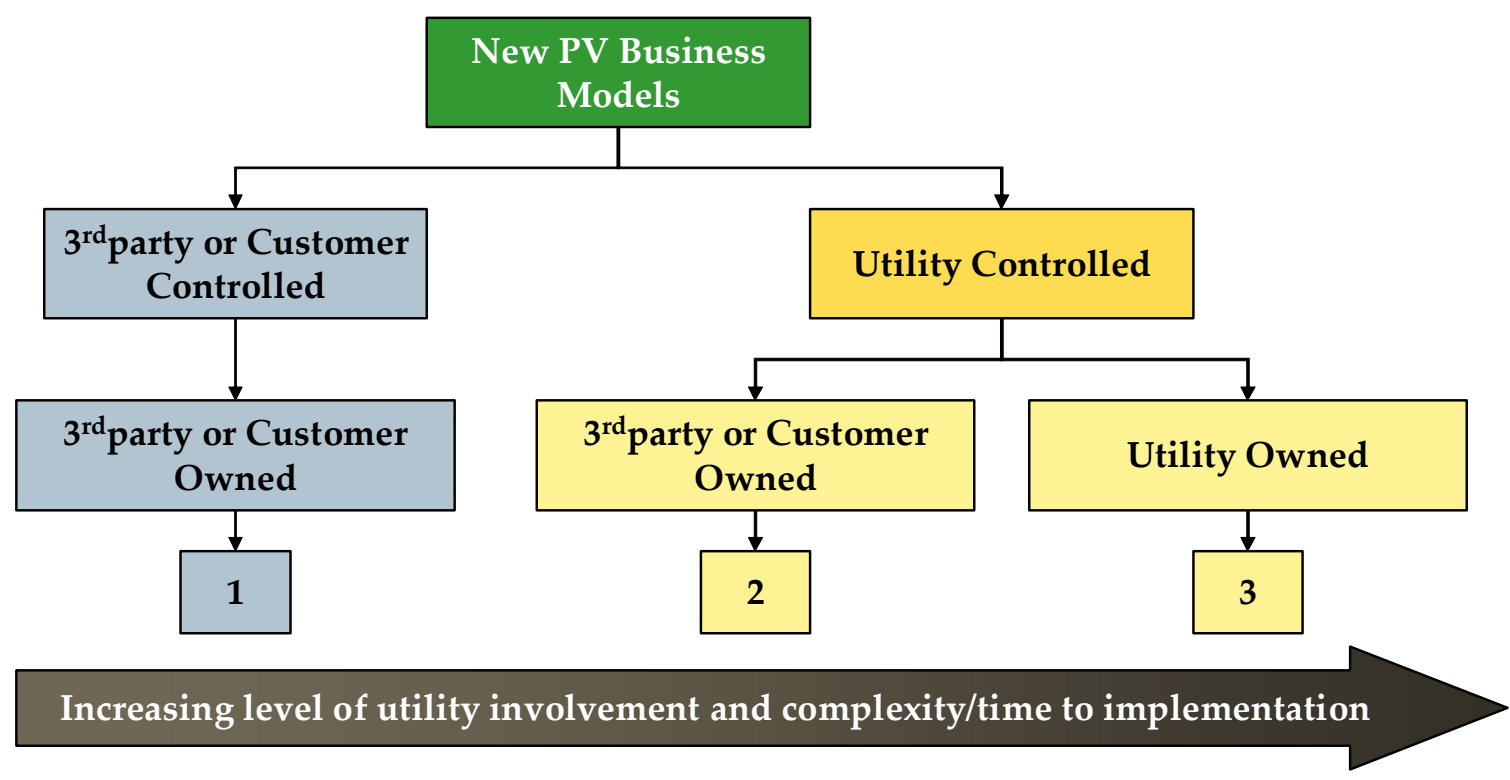

Figure ES-1-5. New PV business models focused on system ownership and control

\section{Third Party/Customer Controlled and Owned PV Business Model}

In this business model, the customer or a third party controls the PV system as well as owns it (there is also the possibility of customer ownership combined with third-party control). This business model is primarily an extrapolation of current business models and trends (

Figure ES-1-6). The key difference is that additional sources of revenue are captured by the owner, based on various changes to the regulatory and policy regimes, and on the deployment of "smart grid" technologies and energy storage that is integrated with PV system operation. In this model, the utility role remains mainly one of facilitation, primarily driven by regulatory or policy changes. The utility pays for value-added products and services obtained from the PV system and are then allowed to recover these costs through traditional rate-making proceedings.

This business model is considered the most likely to become established in the absence of outside influence, as various pieces of current regulation and policy are already in place to enable it in some jurisdictions. 


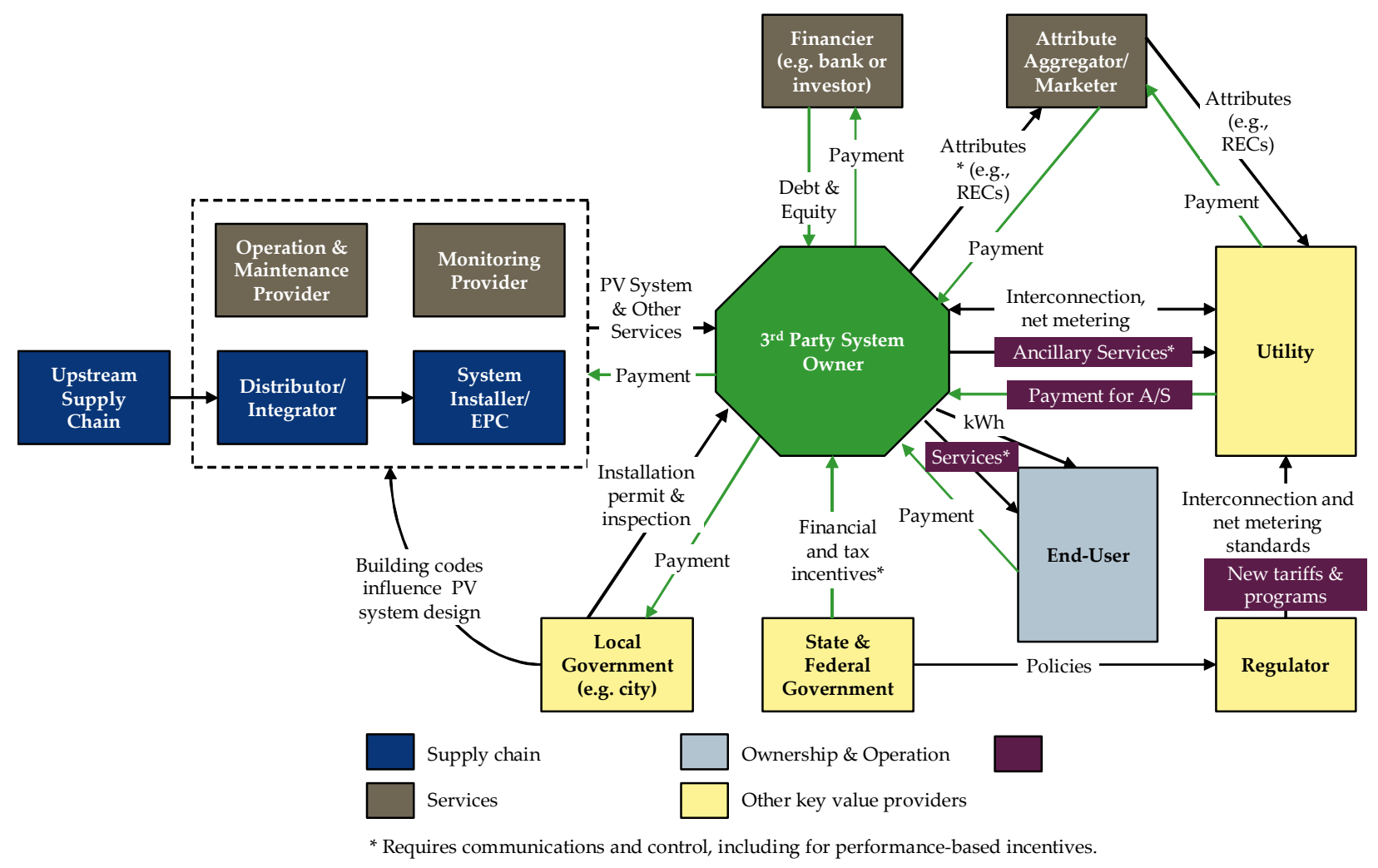

Figure ES-1-6. Third-party/Customer Controlled and Owned Value Network ${ }^{4}$

If the customer/third-party controlled and owned business model becomes widespread, the distribution grid must be re-engineered to be highly responsive to changes in PV operating profiles (e.g., extremely localized power fluctuations), either due to transient changes in sunlight availability or to decisions taken by the owners, because the utility will not control the PV systems. An issue that will arise is the degree to which owners will be "free to choose" how to operate their systems. For example, if a customer chooses to participate in a demand response program, they might be obligated to respond to utility signals.

\section{Utility Controlled, but Third-party or Customer Owned PV Business Model}

This business model is somewhat similar to the one described above, in that it seeks to achieve similar objectives (

Figure ES-1-7). The key difference is that greater utility involvement in the operation and control of the systems is thought to be a way to increase the value of the assets. Like the customer controlled business model described above, regulatory and policy regimes will need to change, though more significantly here, to

\footnotetext{
${ }^{4}$ As an example of this business model, we selected the third-party owned variant, although the end-use owned variant would illustrate the issues as well. In addition, this diagram represents all of the major functions as separate, even though there may integration of some functions as the industry grows and matures.
} 
allow the utility to reach behind the meter where the PV system will reside. In this case, the customer will not respond to price signals because the utility is controlling the PV system, at least to some extent.

This business model may work best where aggressive demand response or other similar programs are being pursued, or where high penetration of PV systems may pose serious grid control and operations issues. Under those circumstances, direct utility control-for example, to allow the utility to curtail PV system operation to maintain grid stabilityinstead of a complicated market for such services, may be preferable because the utility is assured response as it controls the asset as opposed to relying on optional responses to price signals.

In this model, the utility would still pay for value-added products and services from PV systems and then be allowed to recover these costs through traditional rate-making proceedings. To the extent that PV systems provide a service and create value (e.g., avoid costs) for the utility, this would be factored into the cost of recovery calculation.

This business model is expected to evolve more slowly given the additional regulatory changes required to permit utility control behind the meter. Additionally, distributed PV needs to exist at a significant scale in order for a utility to find value in controlling it. For example, the distributed PV installation would have value to the utility proportional to its capacity to substitute for generation, capacity, and transmission and distribution (T\&D) investments. 


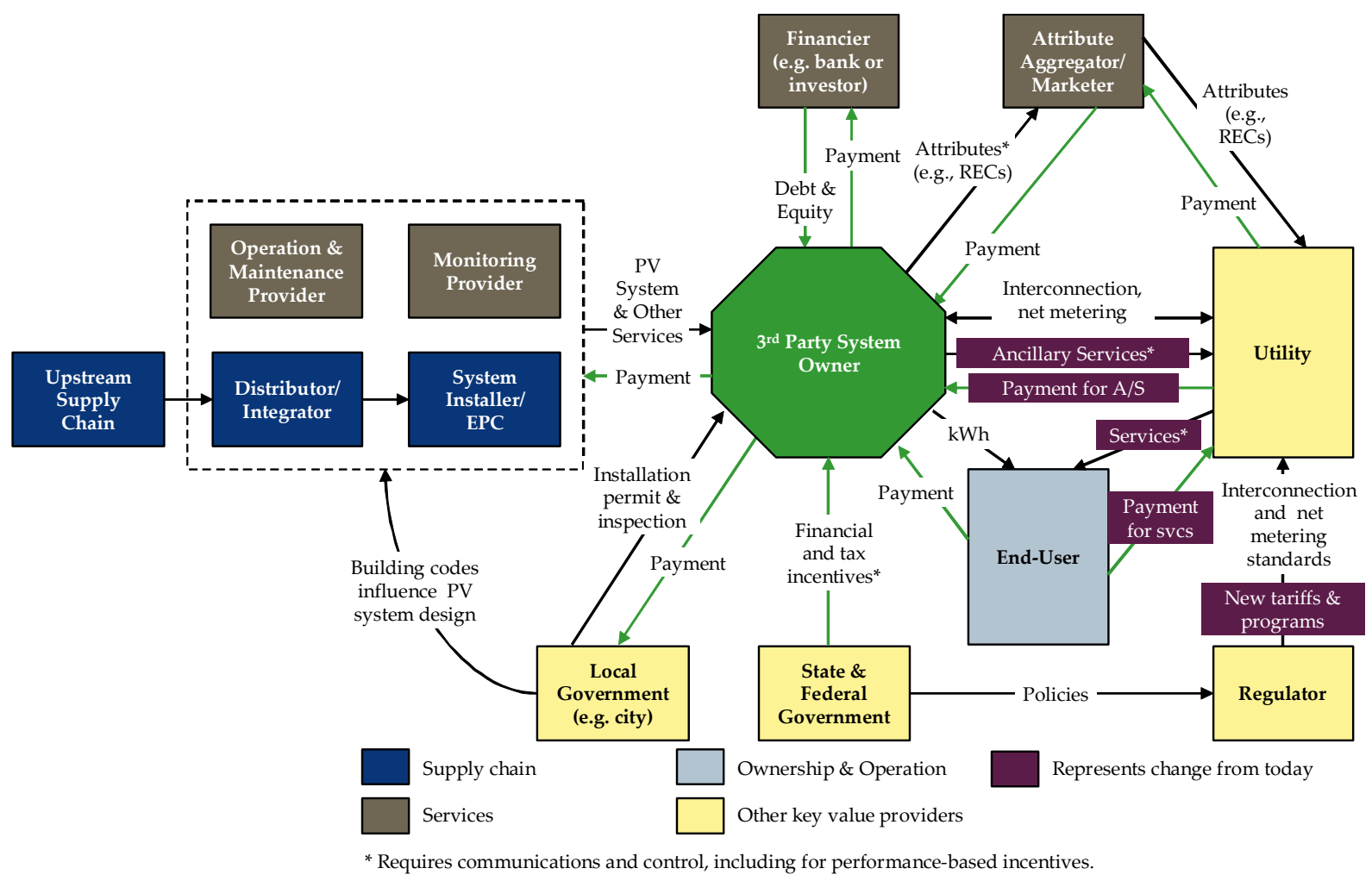

Figure ES-1-7. Utility Controlled but Third-party/Customer Owned Value Network ${ }^{5}$

The requirements for the utility controlled, customer/third-party owned business model are largely the same as for customer/third-party controlled model. The key difference is the regulatory regime, which would enable utility to control significant assets on the customer side of meter. To the extent that utility control is not just for grid benefits but also to enable the utility to offer other services to the end user, these regulatory changes will need to address the rules governing competition for providing these services. The main competitive issue is that the utility, as a monopoly, has an unfair advantage in its access to the customer. If the utility is allowed to access assets behind the meter for the benefit of the grid, but then is also allowed to leverage this access to offer customerbased services like backup power or energy management, other companies without such access might see this as unfair. To the extent that utilities are allowed to use the PV assets to provide value-added services to those customers who own them, the structure and pricing of these services must be determined in a transparent and equitable manner.

\footnotetext{
${ }^{5}$ As an example of this business model, we selected the third-party owned variant, although the end-use owned variant would illustrate the issues as well. In addition, this diagram represents all of the major functions as separate, even though there may integration of some functions as the industry grows and matures.
} 


\section{Utility Controlled and Owned PV Business Model}

This business model represents the greatest departure from today, as the utility reaches unequivocally behind the meter to own assets and provide a range of services to customers (Figure ES-1-8). This model seeks to unlock greater distributed PV value by involving the utility directly in both ownership and control of the asset, and in monetization of the asset's value. This arrangement fits well with utility core competencies of asset ownership and operation. Given that PV is a capital-intensive asset, there is merit in putting such utility-owned assets in the rate-base.

By allowing the utility the greatest control over the placement and subsequent operation of the asset, this model should generate the greatest overall value for the utility. Moreover, in this model, the utility can readily incorporate the grid benefits into its basic cost of service, as well as sell value-added services to the end-user. Of the three groups of business models, this one is the easiest model for the utility to incorporate deployment of PV into their capital planning, as the ultimate decision to install is in their control. However, the issue of competition will be a complication as the utility could have unfair advantage in providing value-added customer-oriented (vs. grid oriented) services that a third party may want to provide.

Like the other business models described above, regulatory and policy regimes will need to be changed significantly to allow the utility to reach so overtly behind the meter. To mitigate the potential scope of such regulatory and policy changes, the PV systems could be located on customer premises but placed on the utility side of the meter. In the past, states have prohibited utilities from owning and operating distributed energy resources (DER) because of concerns regarding market power. This concern will need to be addressed if and when PV systems become very inexpensive or otherwise attractive to utilities.

This business model is expected to evolve more slowly than the others, given the additional regulatory changes required to permit utility control and ownership. Additionally, in order for utility control to have significant value to the utility, distributed PV has to exist on a sufficient scale to have material impact on key values such as ability to offset generation, capacity, and T\&D investments. 


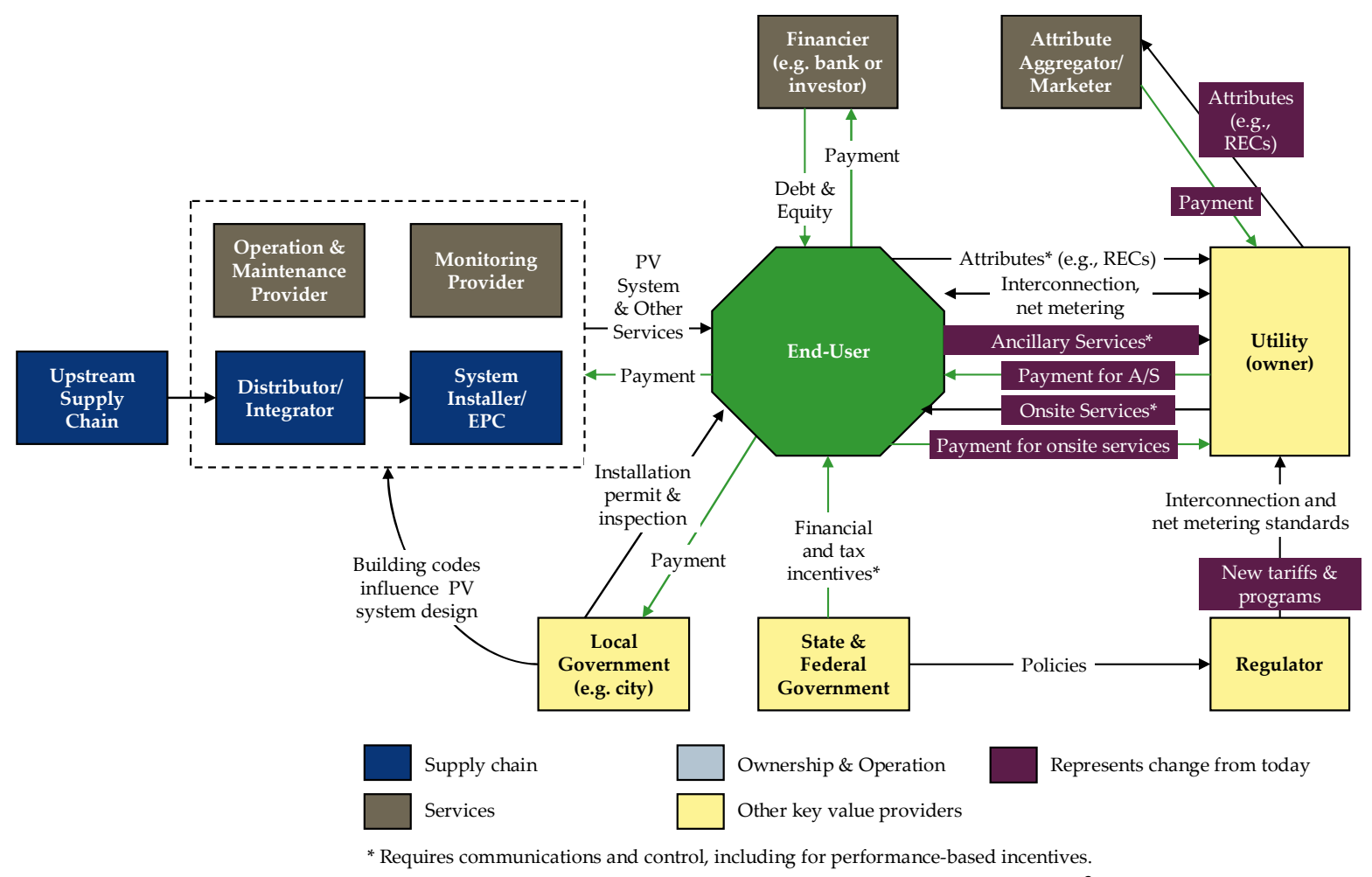

Figure ES-1-8. Utility controlled and owned value network ${ }^{6}$

In a business model where the PV assets are both controlled and owned by the utility, the structure of the system-wide control architecture would be different than in models where the customer or a third party either controls or owns the assets. There would be no need to be able to send signals to a large number of owners. Instead, the control of the PV assets would be integrated into the utility's overall distribution network. Moreover, the deployment and use of PV systems would be more readily integrated into the utility's planning processes; PV systems would become extensions of the distribution grid. Thus, as PV is continually added, the utility would have the opportunity to make sure that the grid configuration remains optimal. Also, this business model would likely make it easier for utilities to justify investments required for grid reconfiguration, as this becomes necessary.

\section{Conclusions and Recommendations}

Currently, PV business models revolve around access to lower-cost financing, increasing the efficiency of the supply chain, and reducing hassles and complexity for the customer. These types of incremental improvements will occur naturally as 0 and $1^{\text {st }}$ Generation business models continue to evolve.

Up until this point, there has been little reason to address system control or consider PV aggregation as an explicit policy matter, given the limited number of PV systems installed on the distribution grid. However, a time will come-in some areas of the

\footnotetext{
${ }^{6}$ This diagram represents all of the major functions as separate, even though there may integration of some functions as the industry grows and matures.
} 
country, much sooner than others - when the sheer number of installed distributed PV systems becomes a material and operational concern — or opportunity - for utilities. Policy and regulatory considerations will then be paramount.

The most significant finding in this study to date is that the full benefits of an extensive distributed PV resource are not likely to be realized without some degree of utility control and ownership. The need to have active management and control of an increasingly large number of distributed PV systems implies that utilities will most likely become more involved in one way or another. As market penetration increases, distributed generation will reach a scale (i.e., generally greater than $100 \mathrm{MW}$ ) that could translate to significant value. For example, utility involvement could help optimize distributed PV assets by incorporating them into grid and generation planning. This is likely to reduce new peaking power requirements, distribution substation upgrades, and other system investments, thus unlocking latent value in the electric grid as a whole.

The results of the analyses performed in this series of DOE studies show that the real value of PV lies in its potential to offset generation, capacity, and T\&D investment. Such value greatly outweighs the value PV has for providing ancillary services on the distribution grid. Therefore, business model development will not be driven by the potential for ancillary grid services. It is the possibility that a large quantity of distributed PV systems will be installed that provides the greatest potential benefit to the nation's energy infrastructure, as these systems in aggregate could actually offset significant investment requirements in new generation, transmission, and distribution capacity.

Through its efforts on Renewable Systems Interconnection, DOE is investing in understanding how technologies on the distribution grid can make significant contributions to meeting future electricity demands. Continued work on business models is a natural complement to this, as business models will facilitate how all of the technologies ultimately come together and transfer value to stakeholders. The future business models described in this report will require changes to industry structure, which implies risk for key stakeholders. DOE is in a position to work with key stakeholders to help mitigate some of the risk involved in pursing these new approaches.

To understand the potential real costs and benefits, promising future business models will need to be piloted at a sufficient scale, requiring significant time and investment. Today, the exact scope, duration, and scale of the business model pilots required is not clear because many issues still need to be addressed. It is critical that key stakeholders are engaged in understanding exactly what is holding back the development of these business models, because many of these companies and organizations are actively considering, right now, what the future will look like and how they will participate. In addition, explicit business model development should be coordinated with work on smart grid capabilities (e.g., distribution automation and advanced metering infrastructure), energy load management (e.g., demand response) and other distributed resource technologies. All of the business models discussed in this report will require integration with these other emerging technologies and capabilities, as well as PV. Because of the potential fundamental changes in regulation, technology, ownership, control, and grid management 
implied by the former, it is premature at this point for DOE to issue an RFP to pilot new business models. As an alternative to immediate pilot activity, we recommend the following three-phase approach which is illustrated in

Figure ES-1-9:

- Phase 1 - Build the Foundation

- Phase 2-Develop the Scope

- Phase 3 - Pilot Business Models and Fund Other Supporting Activities

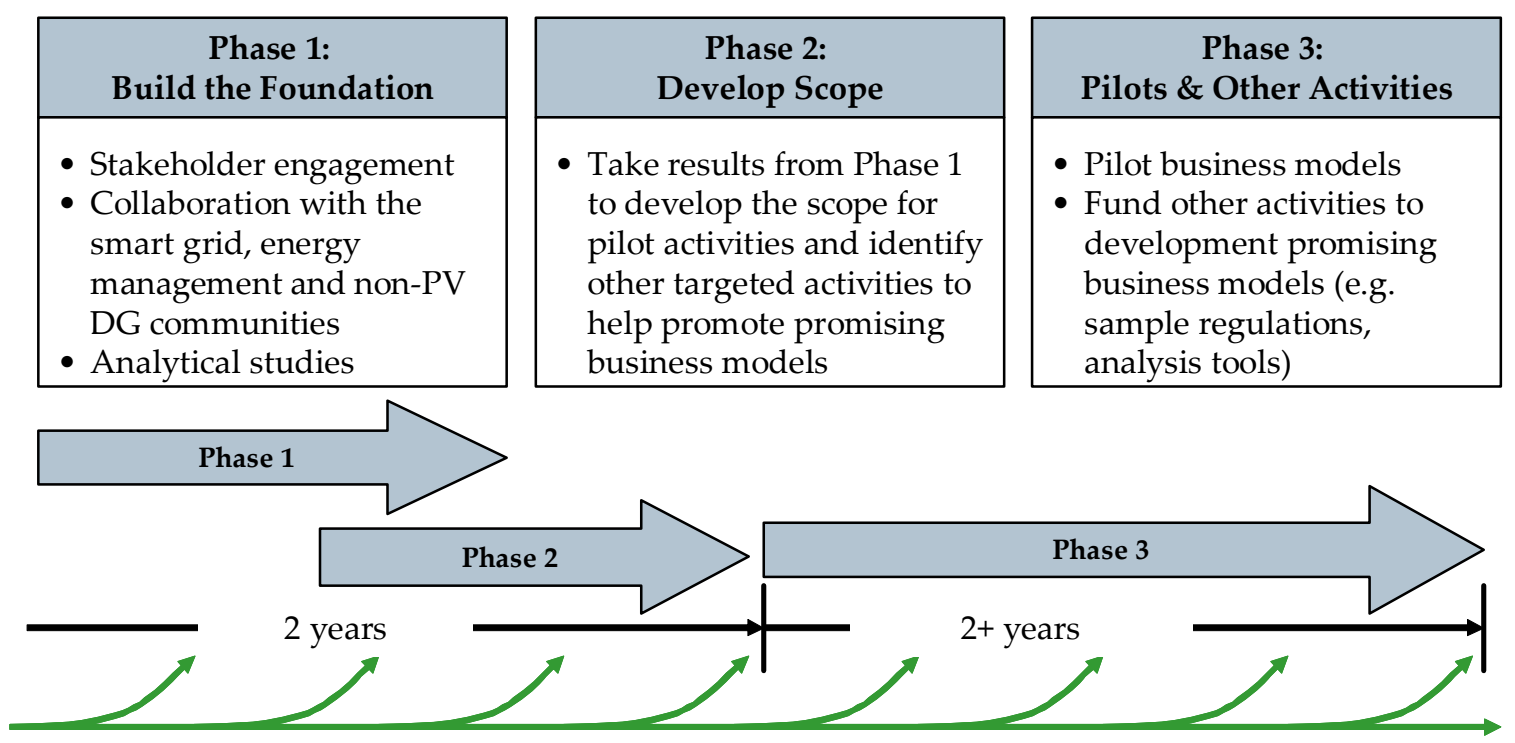

DOE efforts on Renewable System Interconnection will inform business model pilots

Figure ES-1-9. Three phase approach to developing business model pilots

Work in Phases 1 and 2 involve studies and preparation for future business model pilots. These first two phases will likely take one and a half to two years. This additional time will allow the industry to mature and the pace of PV deployment to increase so that it is more likely to achieve a scale sufficient to support business model pilots in Phase 3 . These recommendations are detailed in the full report, which follows. 


\section{Table of Contents}

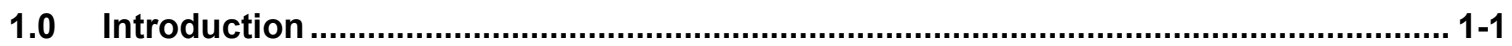

1.1 Background and Context......................................................................... 1-1

1.2 Study Objectives and Scope.................................................................. 1-2

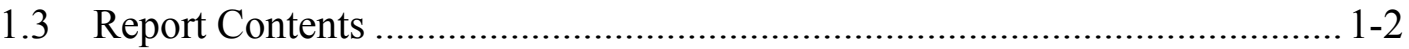

2.0 Current Status of Existing Research ................................................................ 2-1

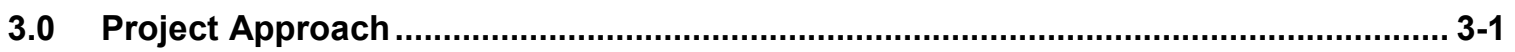

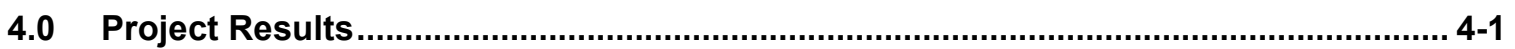

4.1 Definition of PV Business Models and Industry Structure............................ 4-1

4.1.1 PV Product Supply Chain and Value Network.................................. 4-1

4.1.2 Business Models Defined ................................................................. 4-2

4.1.3 Evolution of PV Business Models ……………………….............. 4-3

4.2 Current PV Business Models ............................................................... 4-5

4.2.1 Overview of Approach..................................................................... 4-5

4.2.2 Types of Ownership and Application ............................................... 4-5

4.2.3 Comparison of Current Business Models ........................................... 4-8

4.2.4 Utility Involvement in Current PV Business Models ....................... 4-17

4.2.5 Innovative State Programs Encouraging Current PV Business Models................................................................................ 4-21

4.2.6 Observations ............................................................................. 4-22

4.3 Future Business Models .......................................................................... 4-23

4.3.1 A Long-term Vision for PV ....................................................... 4-23

4.3.2 Other Developments and Considerations........................................... 4-25

4.3.3 Utility Structure and Core Competencies ...................................... 4-26

4.3.4 Maturation of the PV Value Network ........................................... 4-29

4.3.5 New PV Business Models.............................................................. 4-30

5.0 Conclusions and Recommendations for Future Research ...................................... 5-1

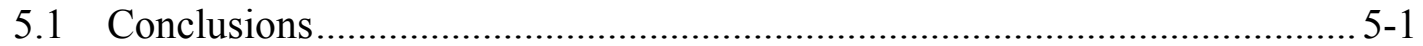

5.2 Recommendations for Future Research ……………................................. 5-2

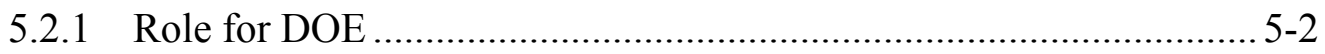

5.2.2 Phase 1: Build the Foundation ........................................................ 5-3

5.2.3 Phase 2: Develop the Scope .............................................................. 5-6

5.2.4 Phase 3: Pilot Business Models and Other Supporting Activities ..... 5-7

6.0 References

7.0 Appendix: Case Studies of Current Business Models............................................... 7-1

7.1 End-user Owner/Residential Retrofit: Borrego Solar .................................... 7-1

7.2 End-user Owner/Residential New Construction: Old Country Roofing........ 7-3

7.3 Third-party Owner/Commercial Retrofit: SunPower ..................................... 7-5

7.4 Third-party owner/Grid-Sited: SunEdison..................................................... 7-7 


\section{List of Figures}

Figure ES-1-1. Evolution of PV business models ........................................................ viii

Figure ES-1-2. Leading PV Ownership-Application models today ............................... ix

Figure ES-1-3. Example of Value Network: End-user Owned Residential Retrofit........

Figure ES-1-4. External factors with implications for PV market development........... xiii

Figure ES-1-5. New PV business models focused on system ownership and control ... XV

Figure ES-1-6. Third-party/Customer Controlled and Owned Value Network ............ xvi

Figure ES-1-7. Utility Controlled but Third-party/Customer Owned Value

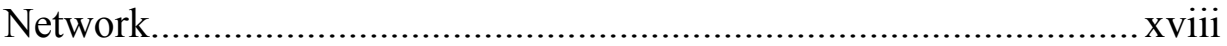

Figure ES-1-8. Utility controlled and owned value network ........................................

Figure ES-1-9. Three phase approach to developing business model pilots ................ xxii

Figure 4-1. Basic components of PV product supply chain ................................. 4-1

Figure 4-2. $\quad$ PV product supply chain and value network ................................... 4-2

Figure 4-3. $\quad$ Evolution of PV business models ........................................................ 4-4

Figure 4-4. Key grid-connected applications in the United States ......................... 4-7

Figure 4-5. Leading PV Ownership-Application models ....................................... 4-8

Figure 4-6. Value Network for the End-user Owned/Residential Retrofit model......................................................................................... 4-11

Figure 4-7. Value Network for the End-user Owned/Residential New C onstruction model......................................................................... 4-12

Figure 4-8. Value Network for Third-party Owned/Commercial Retrofit model............................................................................................ 4-13

Figure 4-9. Value Network for Third-party Owned/Grid Sited model................. 4-14

Figure 4-10. A future vision for PV ................................................................... 4-24

Figure 4-11. Ongoing energy sector developments affecting distributed PV

markets ....................................................................................... 4-26

Figure 4-12. Simplified electric power value chain............................................. 4-27

Figure 4-13. Utility core competencies and attributes to leverage for new PV business models

Figure 4-14. New PV business models focused on system ownership and control 4-32

Figure 4-15. Third-party/Customer Owned and Controlled Value Network .......... 4-34

Figure 4-16. Third-party/Customer Owned and Utility Controlled Value Network4-38

Figure 4-17. Utility Controlled and Owned Value Network .................................. 4-41

Figure 5-1. Three-phase approach to developing business model pilots................. 5-3 


\section{List of Tables}

Table ES-1. Examples of Utility Programs Supporting Current PV Business

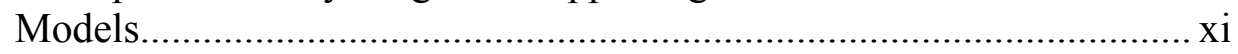

Table ES-2. Examples of Utility PV Ownership ........................................................ xii

Table ES-3. Implications of Widespread Distributed PV Deployment on Key Stakeholders ......................................................................................... xiv

Table 4-1. Possible PV System Owners ................................................................ 4-6

Table 4-2. $\quad$ Leading Business Models ............................................................... 4-9

Table 4-3. Comparison of Business Model Variations and Trends ……….......... 4-15

Table 4-4. Examples of Utility Programs Supporting Current PV Business

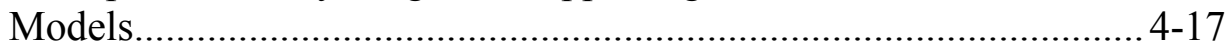

Table 4-5. Examples of Utility PV Ownership ................................................. 4-19

Table 4-6. Innovative State PV Programs ………………………...................... 4-22

Table 4-7. Implications of Widespread Distributed PV Deployment on Key

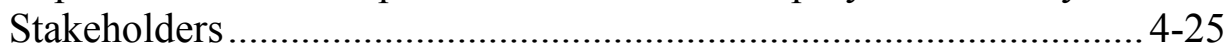

Table 4-8. Maturation of the PV Value Network ................................................ 4-29

Table 4-9. Business Model Variations for Third-party/Customer Owned and

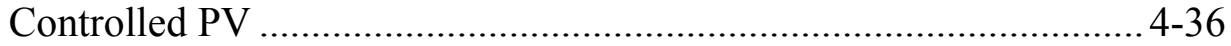

Table 4-10. Business Model Variations for Third-party/Customer Owned and Utility Controlled PV .................................................................... 4-39

Table 4-11. Business Model Variations for Utility Owned and Controlled PV..... 4-43

Table 7-1. Case Study: Borrego Solar................................................................ 7-1

Table 7-2. Case Study: Old Country Roofing ……………………..................... 7-3

Table 7-3. Case Study: SunPower.............................................................. 7-5

Table 7-4. Case Study: SunEdison .................................................................. 7-7 
xxvi 


\subsection{Introduction}

\subsection{Background and Context}

U.S. grid-tied PV markets are growing rapidly. Between 2001 and 2006, the U.S. gridtied PV market had a $46 \%$ compound average rate of growth (CAGR). The US grid-tied market is expected to continue strong growth between 2006 and 2011 with a CAGR of $50 \%{ }^{7}$ Nevertheless, in relation to the overall size of the power sector, the PV market is very small: $<<1 \%$ of total installed capacity. As such, the effects of distributed PV on the electricity grid today are minimal. This applies to both ongoing utility operations and utility planning (capacity, transmission \& distribution investments). Consequently, utilities are generally not involved in the PV value network, except as it relates to the provision of net metering tariffs and standardized/simplified interconnection, and even then, these services are generally offered to fulfill to a regulatory requirement, with the utility maintaining a largely passive role once the PV system is in operation.

However, as PV market penetration grows, its presence on the grid will begin to have a larger impact on grid operations and planning, and more generally, on how utilities conduct their business. This applies to vertically integrated utilities and distribution companies in unbundled power markets, as well as other key players in the electric power sector, including wholesale generators, power marketers and transmission companies.

As the PV value network matures and becomes more efficient, there are policy, technology, and regulatory changes that will enable and/or require higher market penetration of distributed PV. This suggests that the business models that characterize the current PV value network will continue to evolve and that new business models may also emerge, particularly those that have greater levels of utility involvement. Ideally, these new business models should do more than simply respond to potential problems that arise from higher levels of PV market penetration, but anticipate them and thus mitigate or avoid them altogether.

Today, leading edge PV business models focus on third-party ownership, primarily as a means of addressing the barrier of the high up-front cost of the systems. This improves access to greater amounts of lower-cost capital, optimizes the value of existing incentives and therefore makes the technology accessible to a broader market. These innovations, along with improvements to the end-user ownership model, are a sign of increasing sophistication and scale within the PV value network, but are largely about achieving higher levels of efficiency under current cost and incentives structures and regulatory regimes. While extremely important, these business models do not address the fundamental issues that will eventually arise as PV market penetration reaches levels where it will begin to materially impact utilities and grid operations.

\footnotetext{
${ }^{7}$ NCI PV Services, September 2007.
} 


\subsection{Study Objectives and Scope}

The objectives of the study presented here are to:

- Document current and emerging PV business models;

- Identify a range of potential future business models that enhance the value of PV to key stakeholders and thus increase market penetration (e.g., by incorporating energy storage, controls, and other technologies which allow the system to be independently controlled and dispatchable); and

- Discuss how promising potential future business models might be encouraged in the marketplace by government action, including DOE-sponsored research, development, and deployment (RD\&D).

The basic premise explored in this report is that large amounts of distributed PV create a new paradigm that has the potential to radically alter a utility's business model. Of all stakeholders involved, it is the utility that will have its existing business model most disrupted as the PV market expands. However, it is also the utility that has the potential to best utilize the unique, quantifiable benefits of the electricity generated by a PV system.

\subsection{Report Contents}

Section 2 provides a brief review of prior work in this area. In Section 3, the project approach is discussed. Section 4 contains the results of the work, as follows:

- Section 4.1 provides background on the PV value network and defines the term "business model" as used in this report.

- Section 4.2 categorizes dominant PV business models today based on system ownership and application, describes current and emerging PV business models, and provides detailed case studies on current leading-edge business models and utility involvement.

- Section 4.3 articulates a future vision for high penetration of PV, with emphasis on implications for distributed generation (like PV) and utilities. It identifies potential future PV business models, considering: alternatives for ownership and control, opportunities for expanded utility roles, and use of energy storage, controls, and other advanced technology packages. It also identifies challenges for these new business models.

- Section 5 summarizes the conclusions of this study and identifies and prioritizes possible actions for government to encourage promising business models. 


\subsection{Current Status of Existing Research}

Private industry is constantly engaged in advancing PV business models, like the ones discussed in Section 4.2 of this report. However, much less work has been done by government to support development and implementation of new PV business models. Recent business model research supported by the public sector includes:

- The Public Interest Energy Research (PIER) group in the California Energy Commission held a workshop in 2004 with key stakeholders and then provided grants to advance PV business models to support the Zero Energy New Homes Initiatives.

- The Electric Power Research Institute (EPRI) conducted a program in 2006 and 2007 called STAC, to create and demonstrate utility incentives for distributed energy resources, including PV. The work was supported by California Energy Commission, Massachusetts Technology Collaborative, and the State Technologies Advancement Collaborative. The stakeholders involved in the project included government, utilities, vendors, developers, consumer representatives, and public interest groups. No pilots as of yet have resulted from this project and the results of the study are not yet available to the public.

- The Department of Energy (DOE) is currently supporting the Solar Electric Power Association (SEPA) to develop new PV utility business model concepts via working groups. The results from the working group are expected in early 2008. 
2-2 


\subsection{Project Approach}

Using in-house experience and drawing upon prior work in the area of PV business models, the starting point for the analysis was to identify and describe dominant and emerging PV business models. This work also entailed describing the PV product supply chain and the value networks ${ }^{8}$ associated with the various business models. We also identified companies that would be profiled to provide case studies for the key business models.

We reviewed several recent reports and presentations on both PV business models and distributed generation, more generally. Our initial characterizations were also reviewed with various stakeholders via telephone interviews and in person at the Solar Power 2007 conference.

Each of the main business models, dominant and emerging today, were then characterized in a structured way to help identify barriers, important business model variations, and trends.

The results of these characterizations then served as the basis for developing hypotheses of what new business models would look like. An important part of developing future business models was to articulate a long-term vision for PV, with an emphasis on the implications for electric utilities faced with high levels of PV deployment on the distribution grid (i.e., $>10 \%$ of peak demand).

Using internal expertise and subject-matter experts in PV, distribution system automation, energy management, and utility trends, we developed a structured view of possible future business models, emphasizing alternatives for ownership and control, opportunities for expanded utility roles, and use of energy storage, controls, and other advanced distribution system technologies. These future business models were also reviewed with external stakeholders.

Finally, based on the detailed characterizations of these business models, we identified the challenges for implementation and developed recommendations for research, development, demonstration, and focused on ways that government action might encourage the promising business models.

\footnotetext{
${ }^{8}$ The value network describes the relationships between the different stakeholders, and describes how business creates, sells, and delivers value to customers.
} 
3-2 


\subsection{Project Results}

\subsection{Definition of PV Business Models and Industry Structure}

\subsubsection{PV Product Supply Chain and Value Network}

Before current PV business models could be defined and analyzed, it was necessary to identify on which part of the PV value network this report would actually focus. This was done by first mapping the upstream and downstream components of the PV product supply chain, from the raw silicon material input to the final system installation output. Although growth and investment in the upstream supply chain are currently a major focus of the industry, this report focuses on the downstream portion of the supply chain - any activity following the module assembly and first point of sale into the marketplace. This is where grid impact is determined and where different models of system operation and control will occur, both issues of interest to DOE (Figure 4-1).

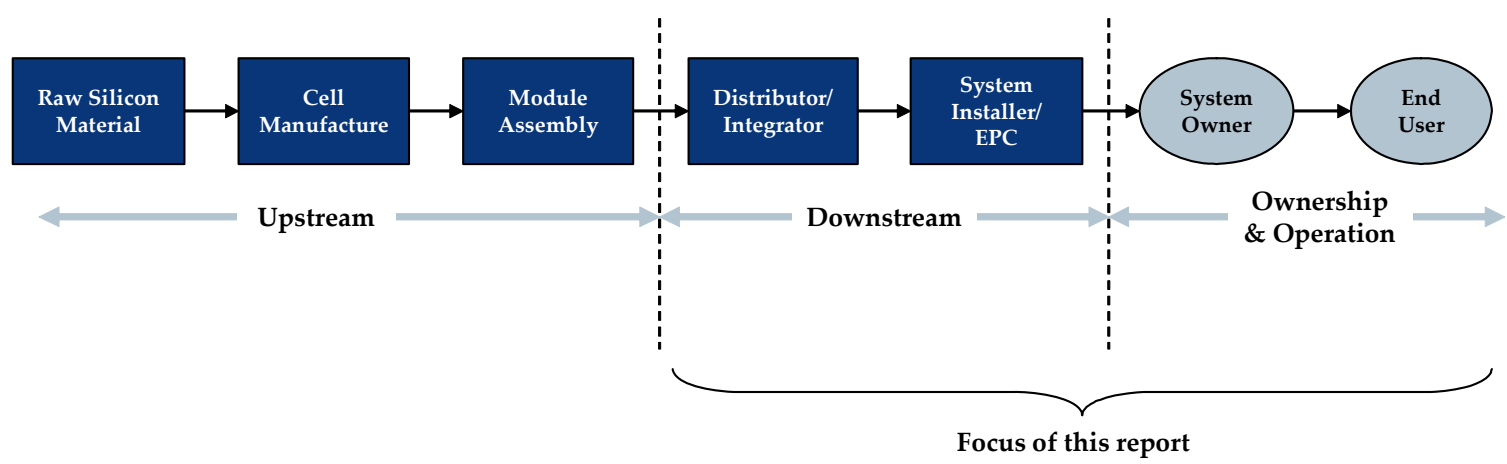

Figure 4-1. Basic components of PV product supply chain

Considering more closely the downstream portion of the supply chain, there are several additional services and participants that play important roles in the PV marketplace. Figure 4-2 below illustrates the expanded value network beyond the PV product supply chain. The value network incorporates key services and participants that add value or otherwise exert influence on the development of the PV market and the types of business models that can exist. The red box indicates the focus of this report, which is primarily around models of PV ownership and operation, which include the end-user. 


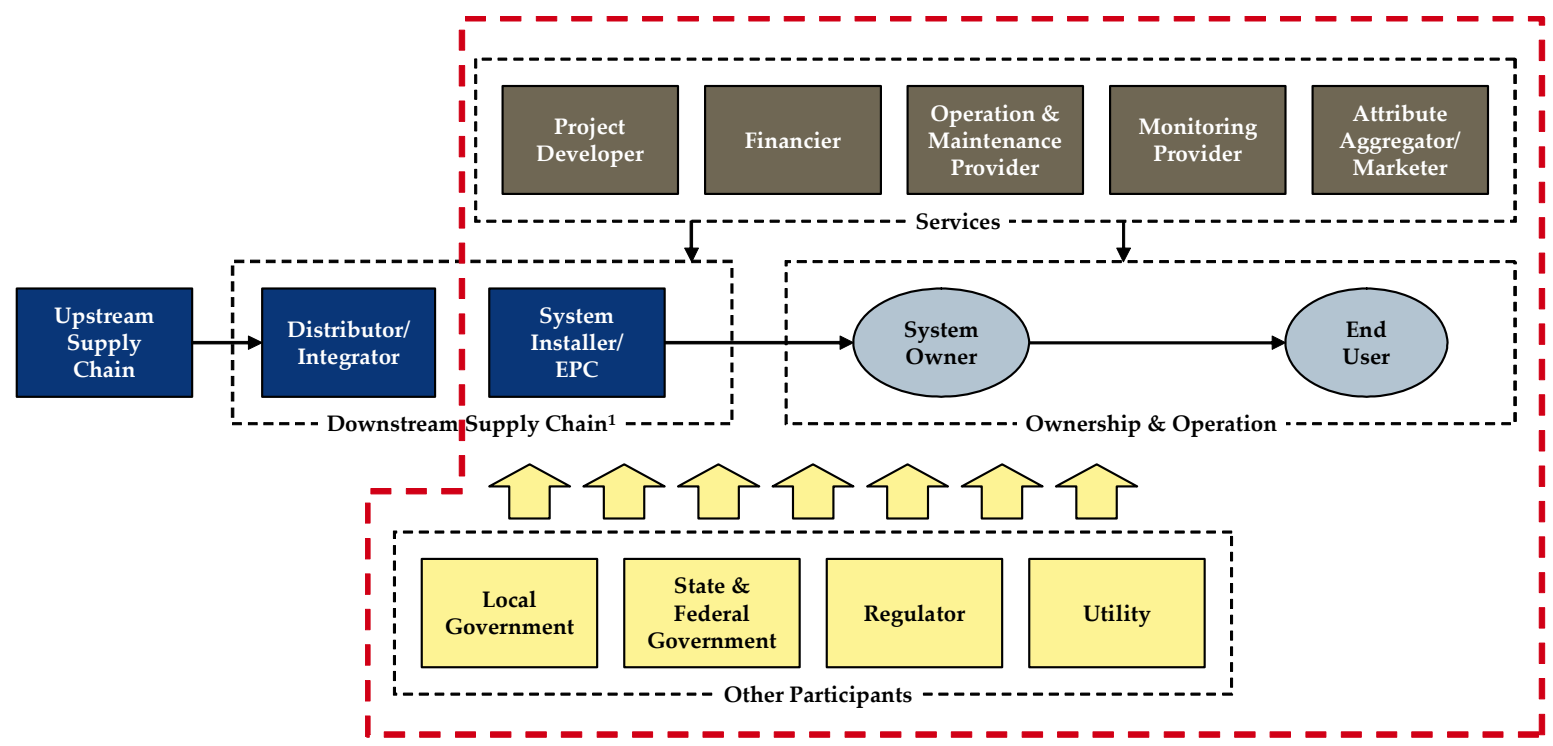

Figure 4-2. PV product supply chain and value network

In the value network in Figure 4-2:

- For clarity, each element of the value network is shown separately, but many could be combined. In particular, the System Owner and End User can be the same entity or separate.

- The System Installer/EPC (Engineer, Procure, Construct) is included insofar as they may take on an ownership/operations role or provide other services.

- Similarly, a Downstream Supply Chain player can simply provide the PV system and installation, or also provide Services and/or interact directly with or be engaged in some way with the Other Participants (e.g., by applying for building permits from Local Government and incentives from State Government).

- Operation, Maintenance, and Monitoring are value-added activities that can be provided by multiple players in the value network, but may not be viable as standalone businesses due to the limited revenue potential. Unlike other power generation businesses, operations and maintenance of PV systems are not two very distinct activities.

- The Attribute Marketer provides a monetary value for the unique attributes of the electricity generated by the PV system (e.g., solar renewable energy credits [SRECs], emissions credits). In the future, this could also extend to generation, transmission, and distribution cost avoidance benefits and grid operations benefits such as voltage support and peak shaving. Various participants in the value network could purchase these attributes.

\subsubsection{Business Models Defined}

A business model, for the purpose of this report, is defined simply as "how a company makes money." This is an important distinction because certain stakeholder activity, a state rebate for example, facilitates the growth of the PV industry, but is not technically a business model. Similarly, situations whereby states may create a market for S-RECs or 
mandate the inclusion of solar on new homes are not new business models. The profitearning business activities that develop around these programs, whatever they may be, are business models.

\subsubsection{Evolution of PV Business Models}

Despite many years of proven field experience and recent growth, PV, as an industry, is still in its relatively early development stages, and still has a significant way to go until it reaches the scale of other similar industries. Globally, the wind power industry is larger, in MW terms, by about an order of magnitude. Other industries that can be considered comparable from a building systems perspective (e.g., HVAC) are much larger and mature, from a product and supply chain perspective, as well as from an installation and maintenance perspective.

The PV industry is moving away from the early approach in which the customer not only owned and financed the PV system, but also managed most aspects of installation. This approach is referred to as the Zero Generation PV business model; its attractiveness was limited to a relatively small group of so-called pioneers who were committed to PV's environmental, energy security, and self-generation benefits. The PV industry has evolved to 1 st Generation PV business models where the product is more attractive to a broader market, moving into the so-called early adopter customer category (see Figure 4-3).

$2^{\text {nd }}$ Generation business models have yet to emerge, but will emphasize greater integration of the PV systems into the grid because emerging technologies and regulatory initiatives are likely to make such integration more viable and valuable. $2^{\text {nd }}$ Generation business models are the focus of the future business models explored in this report, as they are expected to become increasingly important to various stakeholders. 


\section{Evolution of PV Business Models}

0 Generation

PV System Supply $1^{\text {st }}$ Generation

Third-Party Ownership \& Operation $2^{\text {nd }}$ Generation

Full Integration
- Business models focus on manufacturing, supply and installation of PV systems

- End-user is the owner

- Utility is largely passive, providing net metering and standard/simplified interconnection, but otherwise, unaffected.
- Business models driven by third parties which develop projects and own PV systems, resulting in:

- Reduction of hassle \& complexity for end-user

- Better access to financing

- Leveraging of current incentives structure (especially for commercial building applications)

- Utility gradually takes on a facilitation role as PV market share grows
- Business models allow PV to become an integral part of the electricity supply and distribution infrastructure

- Business models emerge with variation of system:

- Ownership

- Operation

- Control

- Utility becomes more deeply involved, as PV becomes major consideration

- PV product supply chain becomes "commoditized"

Figure 4-3. Evolution of PV business models

Although the utility to date has been generally reactive to state requirements (e.g., net metering, standardized interconnection), it is expected to become proactive in the distributed PV market as it is pushed to key stakeholder status. Once PV reaches significant market penetration (perhaps $10-15 \%$ of a utility's peak load), utility involvement will be driven by concerns for grid infrastructure, safety, and of course, revenue erosion. An appropriate business model can promote and accelerate the utility's willing promulgation of PV and help unlock its full value. 


\subsection{Current PV Business Models}

\subsubsection{Overview of Approach}

The analysis of current PV business models began by identifying dominant and emerging models based on the type of system ownership and the application. These two aspects were chosen for the following reasons. First, changes to system ownership have been and are expected to be a key driver of additional market growth. Second, current business models vary significantly by the application, as much of the focus of Zero and $l^{\text {st }}$ Generation business models is on the supply chain and getting product, financing, and related services to customers in more effective ways.

Using this approach, dominant and emerging business models are described and variations and trends for each model are identified. Finally, utility programs and state initiatives that are facilitating the development of the PV market are described. While these utility and state activities are not considered business models, they are important in understanding current utility involvement and increased emphasis by states to promote PV today.

\subsubsection{Types of Ownership and Application}

\subsubsection{Ownership}

The three types of ownership considered in this analysis are: system-user, third-party, and utility. A brief description of each is provided in Table 4-1. 
Table 4-1. Possible PV System Owners

\begin{tabular}{|c|l|}
\hline Owner & Description \\
\hline $\begin{array}{c}\text { System- } \\
\text { user }\end{array}$ & $\begin{array}{l}\text { Generally the owner of the building where the PV system is installed (e.g., a } \\
\text { home or commercial facility) and/or the main user of the power from the PV } \\
\text { system. }\end{array}$ \\
\hline - Traditionally, the system-user has been the dominant owner-type of PV \\
systems in the U.S. System-users were often the pioneer and early-adopter \\
customers that were motivated to purchase a PV system based on its non- \\
economic attributes (e.g., clean energy, independence from utility).
\end{tabular}

\subsubsection{Application}

In the United States, there are two major applications for grid-tied PV: residential and commercial. Utility owned applications (on the utility side of the meter) exist but are still extremely limited in comparison. Of the nearly 2,000 MW of PV deployed worldwide in 2006, grid-tied residential and commercial comprised $42 \%$ and $43 \%$, respectively. ${ }^{9}$

Residential and commercial applications can be further segmented into markets for both new construction and existing (retrofit) buildings. Descriptions and typical system sizes for each type of market are provided below in Figure 4-4.

\footnotetext{
${ }^{9}$ Navigant Consulting PV Service Program, August 2007.
} 


\begin{tabular}{|c|c|c|c|}
\hline \multicolumn{4}{|c|}{ Key Grid-Connected Applications in the US } \\
\hline \multicolumn{2}{|c|}{ Application } & Description & Typical Size \\
\hline \multirow{2}{*}{ Residential } & Retrofit & $\begin{array}{l}\text { - PV modules installed on roofs of existing } \\
\text { homes; average system size increasing }\end{array}$ & $2-8 \mathrm{~kW}$ \\
\hline & $\begin{array}{l}\text { New } \\
\text { Construction }\end{array}$ & $\begin{array}{l}\text { - Increasingly, building integrated products } \\
\text { are installed at time of home construction }\end{array}$ & $1.5-5 \mathrm{~kW}$ \\
\hline \multirow{2}{*}{ Commercial } & Retrofit & $\begin{array}{l}\text { - PV modules installed on roofs of existing } \\
\text { commercial and industrial spaces; average } \\
\text { system size increasing }\end{array}$ & $20-1,000 \mathrm{~kW}$ \\
\hline & $\begin{array}{l}\text { New } \\
\text { Construction }\end{array}$ & $\begin{array}{l}\text { - Increasingly, building integrated products } \\
\text { installed at time of building construction } \\
\text { (especially in Europe) }\end{array}$ & $20-1,000 \mathrm{~kW}$ \\
\hline \multicolumn{2}{|c|}{ Grid-sited } & $\begin{array}{l}\text { - Ground-mounted PV systems installed on } \\
\text { the wholesale side of the distribution grid }\end{array}$ & $>500 \mathrm{~kW}$ \\
\hline
\end{tabular}

Figure 4-4. Key grid-connected applications in the United States

The residential retrofit market is currently the largest, in terms of installed capacity; however, it is one of the slowest growing today relative to other applications. The strongest growth, at greater than $40 \%$ per year, has been seen in the commercial retrofit market. This can be attributed to the emergence of third-party ownership and more attractive economics for system-users (due largely to federal incentives). The remaining three markets - residential and commercial new construction and grid-sited applications — are still relatively small but showing steady growth.

There are five key ownership-application models, as depicted in Figure 4-5. By characterizing the current marketplace using the ownership and application framework, several things become apparent:

- The dominant ownership model has been end-user owned, 0 Generation, models.

- The dominant applications have been both commercial and residential retrofit, not new construction or grid-sited.

- Today, third-party ownership is quickly becoming an established ownership approach for commercial applications, and is also emerging as an ownership approach for grid-sited applications. This is moving the marketplace into the $1^{\text {st }}$ Generation PV business models discussed above.

- Utility ownership of distributed PV has been minimal, as viable business models have been lacking. $2^{\text {nd }}$ Generation models have yet to really take hold. 


\begin{tabular}{|c|c|c|c|c|}
\hline \multirow{2}{*}{\multicolumn{2}{|c|}{ Application }} & \multicolumn{3}{|c|}{ Ownership } \\
\hline & & End-User & $3^{\text {rd }}$ Party & Utility \\
\hline \multirow{2}{*}{ Residential } & Retrofit & O & $\begin{array}{l}\text { Minimal } \\
\text { activity }\end{array}$ & \multirow{2}{*}{$\begin{array}{c}\text { Minimal } \\
\text { activity }\end{array}$} \\
\hline & New Construction & O & $\begin{array}{l}\text { Minimal } \\
\text { activity }\end{array}$ & \\
\hline \multirow{2}{*}{ Commercial } & Retrofit & ? & $\odot$ & \multirow{2}{*}{$\begin{array}{c}\text { Minimal } \\
\text { activity }\end{array}$} \\
\hline & New Construction & $\begin{array}{l}\text { Minimal } \\
\text { activity }\end{array}$ & $\begin{array}{l}\text { Minimal } \\
\text { activity }\end{array}$ & \\
\hline \multicolumn{2}{|c|}{ Grid-sited (utility side of meter) } & NA & O & $\begin{array}{l}\text { Minimal } \\
\text { activity }\end{array}$ \\
\hline En & Somewha & ablished $\odot$ & Most Establ & \\
\hline
\end{tabular}

Figure 4-5. Leading PV Ownership-Application models

\subsubsection{Comparison of Current Business Models}

This section compares four of the leading models shown in the Figure 4-5 including:

- End-user Owner/Residential Retrofit

- End-user Owner/Residential New Construction

- Third-party Owner/Commercial Retrofit

- Third-party Owner/Grid-sited

These models are compared across value networks, variations, trends, and key characteristics, such as: customer profiles, system characteristics, marketing processes, and sources of financing. Value networks were used to show the relationships and value transfer between key stakeholders. The graphic depictions of the value networks were also useful in the study when considering how relationships and flow of values between key stakeholders may change in the future due to the emergence of new business models. Variations on each basic model are included since they provided insight into where innovation is occurring in the marketplace and can be largely correlated with industry trends. In addition to the generic characterizations, the Appendix contains case studies for the four business model types highlighted in this section.

Although the End-user Owned/Commercial Retrofit model is well established, it is not included in the comparison in the next section since it is somewhat similar to the Enduser Owned/Residential Retrofit model and Third-party Owned/Commercial Retrofit model that will be described.

\subsubsection{Comparison of Key Characteristics}

Table 4-2 compares key characteristics of the four business model types highlighted in this section. 
Table 4-2. Leading Business Models

\begin{tabular}{|c|c|c|c|c|}
\hline & \multicolumn{4}{|c|}{ Leading Business Models } \\
\hline & $\begin{array}{l}\text { End-user Owner: } \\
\text { Residential Retrofit }\end{array}$ & $\begin{array}{c}\text { End-user Owner: Residential } \\
\text { New Construction }\end{array}$ & $\begin{array}{l}\text { Third-party Owner: } \\
\text { Commercial Retrofit }\end{array}$ & $\begin{array}{l}\text { Third-party Owner: } \\
\text { Grid-sited }\end{array}$ \\
\hline $\begin{array}{l}\text { Customer } \\
\text { Profile }\end{array}$ & $\begin{array}{l}\text { Customers are } \\
\text { typically early adopters, motivated } \\
\text { by attraction to technology, energy } \\
\text { independence, and environmental } \\
\text { benefits (despite all of this, } \\
\text { incentives are still critical to the } \\
\text { market) }\end{array}$ & $\begin{array}{l}\text { Customer of PV is the } \\
\text { buyer of a new home; PV is } \\
\text { sometimes seen as a favorable, } \\
\text { additional asset, especially where } \\
\text { rebates and environmental sentiment } \\
\text { are strong (e.g., California) } \\
\text { In some cases, PV } \\
\text { comes as a standard feature, giving } \\
\text { the homebuyer no choice in the } \\
\text { decision }\end{array}$ & $\begin{array}{l}\text { - Motivation of customer } \\
\text { purchase can be complicated due to } \\
\text { the number of parties potentially } \\
\text { involved; motivations generally include } \\
\text { potential electricity cost savings or } \\
\text { hedge against future electricity rate } \\
\text { escalation and recognition for } \\
\text { environmental leadership (e.g., brand) } \\
\text { - Customer may still have } \\
\text { aspects of early adopters' behavior, } \\
\text { motivated by attraction to technology, } \\
\text { energy independence, and } \\
\text { environmental benefits, but may also } \\
\text { be identified as early majority (since } \\
\text { economics with incentives can be } \\
\text { competitive and most risk is taken by } \\
\text { third party). } \\
\text { - Demand would be } \\
\text { significantly lower without subsidies } \\
\text { and incentives }\end{array}$ & $\begin{array}{l}\text { Utility is } \\
\text { customer for power; driven } \\
\text { by need to comply with RPS } \\
\text { policies Given PV's } \\
\text { - levelized cost of electricity } \\
\text { versus distributed power, } \\
\text { this model currently exists } \\
\text { purely for compliance } \\
\text { purposes }\end{array}$ \\
\hline $\begin{array}{l}\text { System } \\
\text { Characteristics }\end{array}$ & $\begin{array}{l}\text { Average system 4.5- } \\
\text { kWp and even larger in parts of U.S. } \\
\text { Typically covers } 80 \% \\
\text { of end-user annual home load } \\
\quad \text { Primarily crystalline } \\
\text { silicone modules }(\sim 150-300 \mathrm{~W}) \text { and } \\
\text { three-phase inverters } \\
\text { Use of storage and } \\
\text { controls has been minimal (although } \\
\text { prevalent in off-grid homes) } \\
\text { \$9.50/Wac (2006); } \\
\text { LCOE is still generally above } \\
\text { residential utility rates, even with } \\
\text { incentives Interconnection with } \\
\text { - } \\
\text { utility, net metering (available in } \\
\text { most markets) }\end{array}$ & $\begin{array}{l}\text { System size typically } \\
\text { ranges from } 1.5 \text { to } 4.0 \mathrm{~kW} \text {, however } \\
2.3 \mathrm{~kW} \text { is considered the "sweet spot" } \\
\quad \text { Since new homes in } \\
\text { California are often built to Tier } 2 \\
\text { standards, which is } 35 \% \text { above } \\
\text { California code, a } 2.3 \mathrm{~kW} \text { system can } \\
\text { cover } 50-60 \% \text { of a home's load } \\
\text { Increasingly, } \\
\text { homebuilders are using building } \\
\text { integrated PV products which } \\
\text { improve aesthetics } \\
\text { - Inverter size is a } \\
\text { challenge for new homes; inverter } \\
\text { manufactures are following the } \\
\text { residential retrofit trend toward larger } \\
\text { systems, which are oversized for } \\
\text { most new home systems }\end{array}$ & $\begin{array}{l}\text { Installations generally } \\
\text { range from 100-kWp to 1-MWp with } \\
\text { systems as large as } 10-\mathrm{MWp} \text {; recent } \\
\text { trend has been toward larger systems } \\
\text { (reduces transaction cost per watt } \\
\text { installed) } \\
\text { - For retail customers, PV } \\
\text { system typically covers } 30-50 \% \text { of } \\
\text { load; ranges widely for other customers } \\
\text { from a trivial amount to } 100 \% \text {; } \\
\text { limitations on system size include roof } \\
\text { space and interconnection standards } \\
\text { - Use of storage and } \\
\text { controls have been minimal, although } \\
\text { remote monitoring is common } \\
\text { - } 66.25-\$ 8.75 / \mathrm{Wac} \text {; in } \\
\text { some cases where the cost of } \\
\text { electricity is high, systems can be cost }\end{array}$ & $\begin{array}{l}\text { These larger } \\
\text { systems are generally } \\
>1 \mathrm{MW} \text { size }\end{array}$ \\
\hline
\end{tabular}




\begin{tabular}{|c|c|c|c|c|}
\hline & & $\begin{array}{l}\text { Interconnection with } \\
\text { utility grid, net metering (available in } \\
\text { most markets) }\end{array}$ & $\begin{array}{l}\text { competitive with grid including } \\
\text { incentives } \\
\text { - Interconnection with utility } \\
\text { grid, net metering (available in most } \\
\text { markets) }\end{array}$ & \\
\hline $\begin{array}{l}\text { Marketing } \\
\text { Process }\end{array}$ & $\begin{array}{l}\text { Historically there has } \\
\text { been market pull, increased by } \\
\text { government programs that provide } \\
\text { solar high visibility } \\
\text { - Marketing efforts } \\
\text { beyond this are generally only } \\
\text { relevant in key markets where } \\
\text { incentives are driving up consumer } \\
\text { demand (e.g., California, New } \\
\text { Jersey, Colorado, New York) } \\
\text { In addition, local } \\
\text { installers often utilize the Web and } \\
\text { Yellow Pages to generate leads } \\
\text { - More recently } \\
\text { companies are beginning to develop } \\
\text { group selling approaches (e.g., } \\
\text { Solar City holds community } \\
\text { meetings, REC does multi-day road } \\
\text { shows at Costco) }\end{array}$ & $\begin{array}{l}\text { Marketing occurs at } \\
\text { two levels: 1) from manufacturer to } \\
\text { home builders/developers and 2) } \\
\text { from homebuilders to potential new } \\
\text { home buyer } \\
\text { - Many PV } \\
\text { manufacturers have new home } \\
\text { roofing products; SunPower } \\
\text { (SunTile) and BP are key providers } \\
\text { to this market } \\
\text { builders/developers indicate that } \\
\text { solar PV increases foot traffic to new } \\
\text { homes In some cases, } \\
\text { - } \\
\text { homebuilders are building PV into } \\
\text { every home, so PV is not an option, } \\
\text { just a standard part of the home }\end{array}$ & $\begin{array}{l}\text { Historically, there is some } \\
\text { market pull that is increased by } \\
\text { government programs that provide } \\
\text { solar high visibility } \\
\text { - Most companies have } \\
\text { sales teams focused on specific types } \\
\text { of customers (e.g., big-box retail, } \\
\text { RETs) or a specific region. In addition, } \\
\text { some players play a broker role, } \\
\text { bringing existing clients in related fields } \\
\text { to solar developers }\end{array}$ & $\begin{array}{l}\text { To date in the } \\
\text { U.S., systems have been } \\
\text { installed in response to } \\
\text { RFPs }\end{array}$ \\
\hline $\begin{array}{l}\text { Sources of } \\
\text { Financing }\end{array}$ & $\begin{array}{l}\text { Homeowner pays for } \\
\text { system either by using cash or by } \\
\text { accessing a loan, often this takes } \\
\text { place by rolling cost of the PV } \\
\text { system into existing mortgage, } \\
\text { similar to home improvement loans. } \\
\text { - } \quad \text { Loan is often } \\
\text { amortized over 20-30 years to help } \\
\text { reduce monthly payments } \\
\text { - Some utilities are } \\
\text { oporking on creative financing } \\
\text { options (discussed later in report) } \\
\text { Homeowners also } \\
\text { have access to state rebates and } \\
\text { state and federal tax incentives }\end{array}$ & $\begin{array}{l}\text { PV system is } \\
\text { considered an additional feature to } \\
\text { the home and is included in the } \\
\text { home price The homeowner } \\
\text { generally rolls the PV system into the } \\
\text { mortgage State rebates and } \\
\text { federal tax incentives are paid to } \\
\text { homeowner. }\end{array}$ & $\begin{array}{l}\text { Sophisticated financial } \\
\text { systems have been created, like third- } \\
\text { party ownership with purchase power } \\
\text { agreements; these generally have 10- } \\
25 \text { year terms. This relieves the users } \\
\text { from having to fund capital (debt or } \\
\text { equity) and transfers most risk to the } \\
\text { third party Given the ITC for PV, tax } \\
\text { equity financing is available through } \\
\text { large institutions (e.g., investment } \\
\text { banks, commercial banks, larger } \\
\text { corporations) or through brokers who } \\
\text { connect tax equity sources to projects. } \\
\text { State rebates/financial } \\
\text { incentives; tax incentives: federal and } \\
\text { accelerated depreciation }\end{array}$ & $\begin{array}{l}\text { PPA contract } \\
\text { between developer/third } \\
\text { party and utility } \\
\text { Developer/third } \\
\text { party must raise debt/equity } \\
\text { in the marketplace }\end{array}$ \\
\hline
\end{tabular}




\subsubsection{Comparison of Value Networks}

The value network for the End-user Owned/Residential Retrofit model is shown in Figure 4-6. The diagram shows the flow of values and key transactions between the main stakeholders in its most basic configuration. Variations of this basic model are found in the marketplace, and typically emerge from players merging together to offer services (e.g., financing flowing through the system provider), or a stakeholder taking on responsibility for specific transactions (e.g., system provider managing interconnection with the utility, rebates with the state government, and permits from the city).

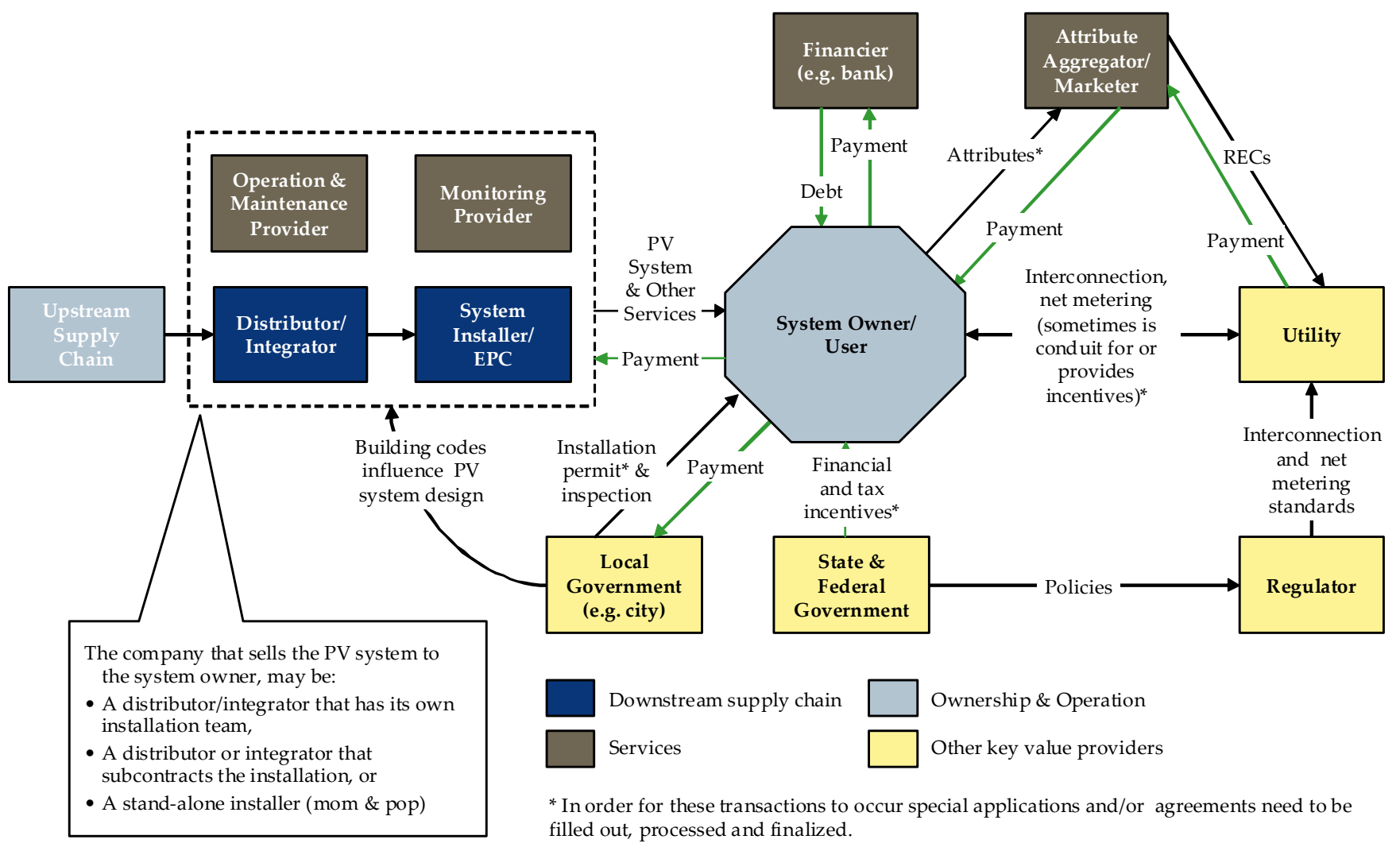

Figure 4-6. Value Network for the End-user Owned/Residential Retrofit model

As would be expected, the value network changes for the other basic models examined in this section changes; these changes are discussed and shown below.

For the End-user Owned/Residential New Construction Model shown in Figure 4-7, the most striking difference from the previous model is the homebuilder as a central player in the installation of the PV system. Instead of the homeowner having ultimate responsibility for many aspects of the installation, it is the homebuilder that must generally manage interconnection with the utility and permits from the city. In this basic case, the homeowner still applies for the rebates and other incentives and manages any 
potential sales of RECs, and ultimately owns the PV system. There are variations to this basic model, which will be discussed later.

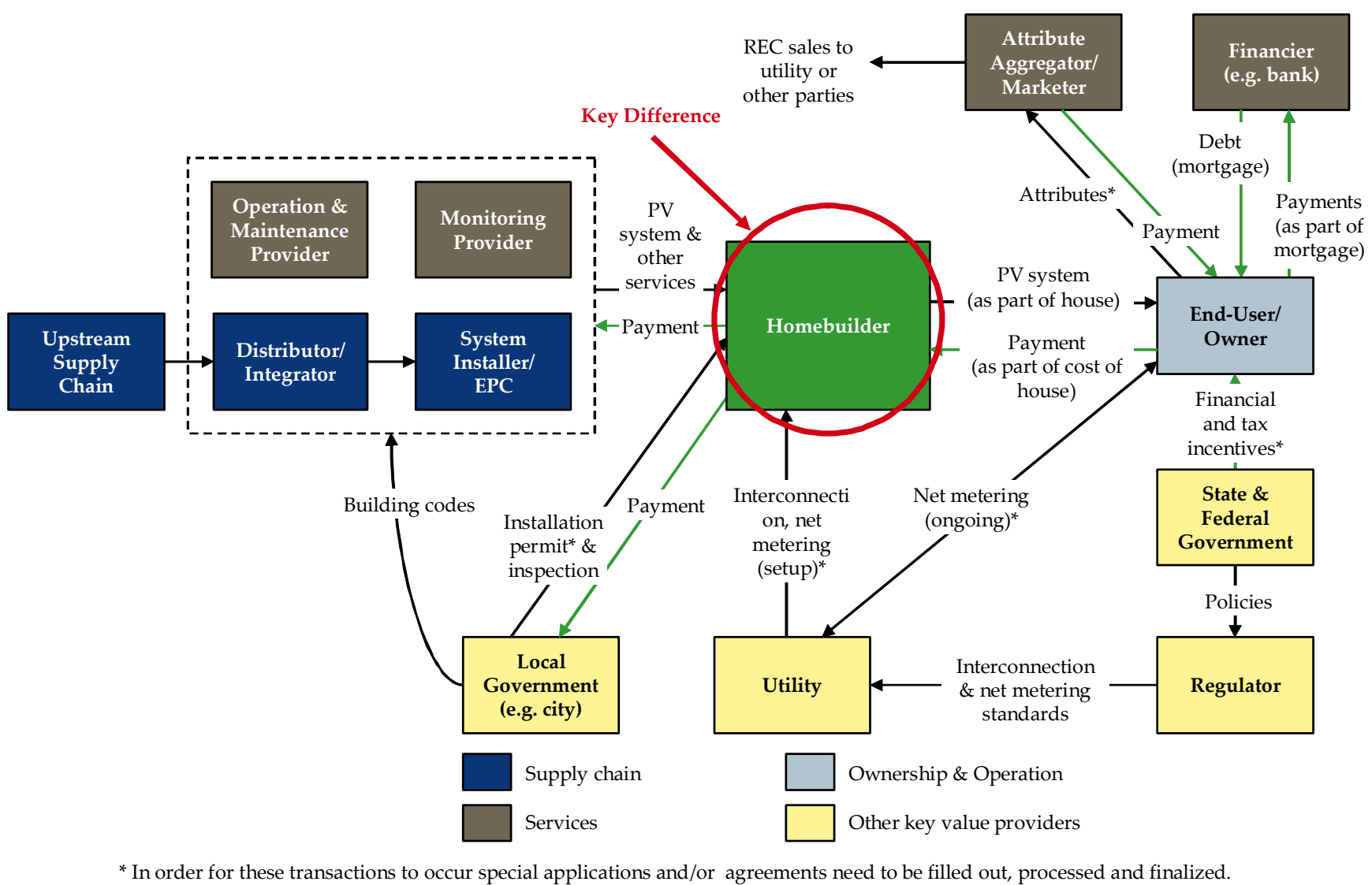

Figure 4-7. Value Network for the End-user Owned/Residential New Construction model

For the Third-party Owned/Commercial Retrofit model shown in Figure 4-8, the most striking difference with the previous model shown is the third-party as the central player, managing all aspects of the installation and then taking on the long-term ownership, operation, and maintenance of the system. The end-user is involved by way of providing roof space and purchasing the electricity ( $\mathrm{kWhs}$ ) that is generated from the system. 


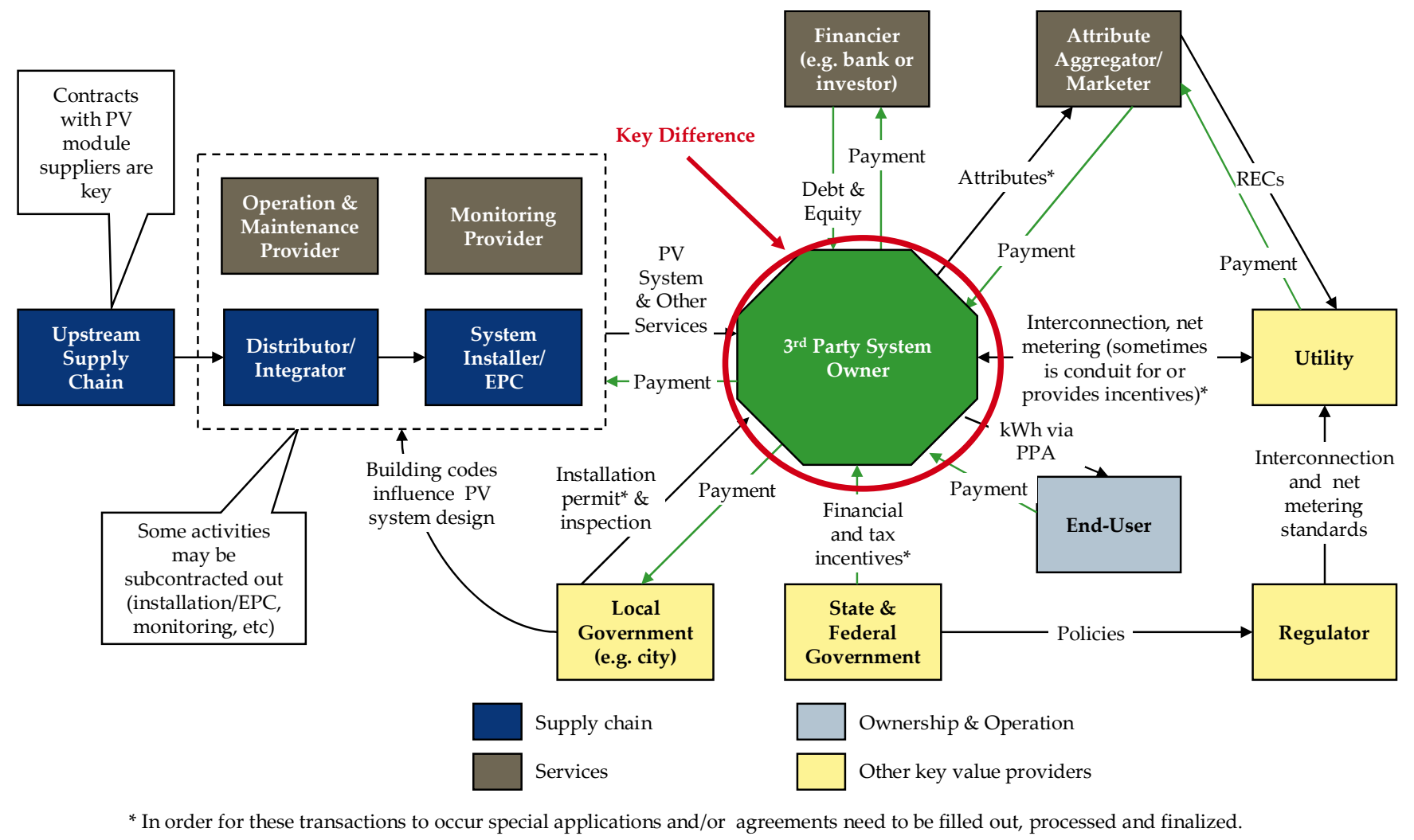

Figure 4-8. Value Network for Third-party Owned/Commercial Retrofit model

Finally, for the Third-party Owned/Grid-Sited model shown in Figure 4-9, the most striking difference from the previous model is that the relationship with the utility moves beyond interconnection and net metering, and now includes the sale of electricity (kWhs). This is a typical arrangement in the electricity sector where an independent generator establishes a purchase power agreement with a utility. 


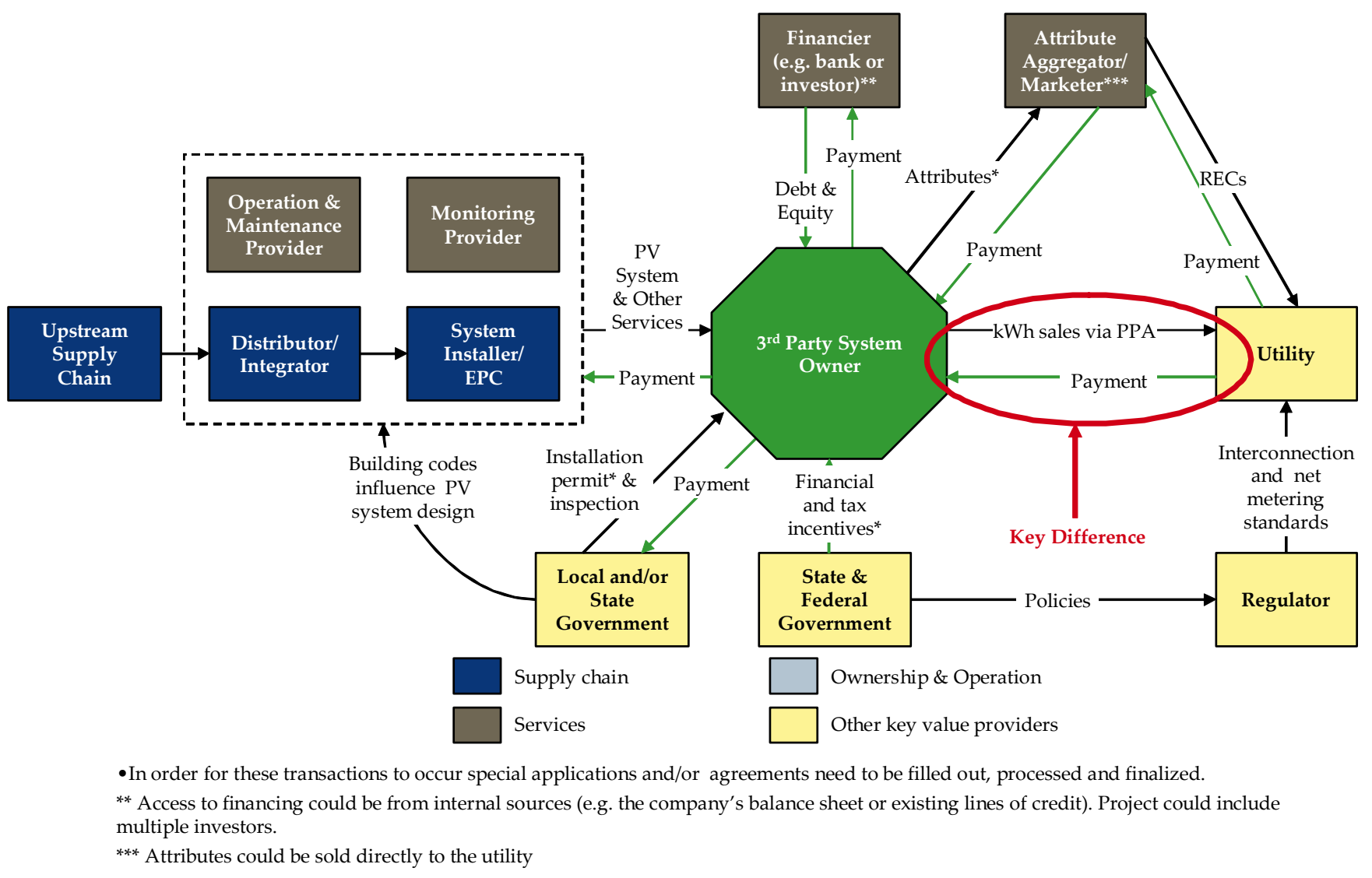

Figure 4-9. Value Network for Third-party Owned/Grid Sited model

\subsubsection{Comparison of Business Model Variations and Trends}

The business models characterized and shown in the sections above are intended to capture the most basic types. For each of the models described, variations exist in the marketplace. These variations allow companies to sell to different customer types (e.g., early adopter versus pioneer) and also demonstrate trends in the industry, such as reducing hassle and complexity for the customer or end-user. Table 4-2 summarizes current variations and trends by model type. Note that the Third-party Owned/Grid-Sited model is not included, as there are so few examples of this type in the United States, thus variations on the basic approach do not yet exist. 
Table 4-2. Comparison of Business Model Variations and Trends

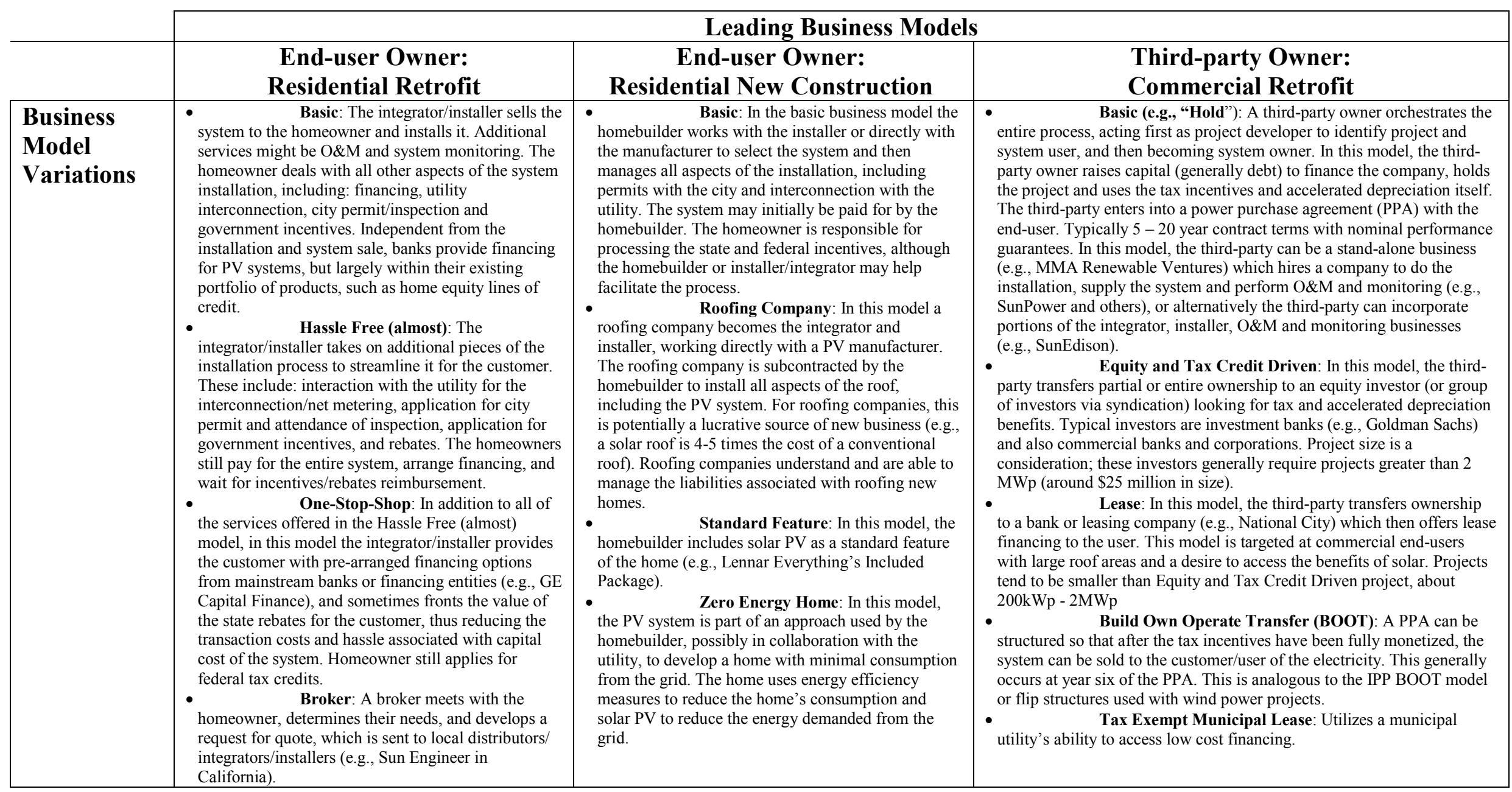




\begin{tabular}{|c|c|c|c|}
\hline $\begin{array}{l}\text { Key } \\
\text { Business } \\
\text { Model } \\
\text { Trends }\end{array}$ & $\begin{array}{l}\text { - } \\
\text { customer } \\
\text { Increased marketplace competition } \\
\text { and commoditization } \\
\text { processes } \quad \text { Increased sophistication of back-office } \\
\text { - } \\
\text { verification, and diagnostics }\end{array}$ & $\begin{array}{l}\text { - } \text { Building integrated products are in } \\
\text { greater demand } \\
\text { PVoofing companies are entering the } \\
\text { PV installation business } \\
\text { PV is becoming a standard feature in } \\
\text { some new home development } \\
\text { efficiency measures in design }\end{array}$ & $\begin{array}{l}\text { - Larger systems especially commercial systems with PPAs, } \\
\text { are tending toward larger sizes } \\
\text { - } \\
\text { Increased number of third-party intermediaries } \\
\text { Increased availability of capital }\end{array}$ \\
\hline
\end{tabular}




\subsubsection{Utility Involvement in Current PV Business Models}

Apart from involvement with net metering and interconnection, historically, utility participation in the PV market was limited to a few cases of retailing PV systems and providing system rebates. These later types of programs were generally undertaken by municipal utilities. However, a growing number of investor-owned utilities have recently taken on more active roles in encouraging the distributed customer-owned PV market. Using our taxonomy of PV business model evolution, this type of utility activity falls under $1^{\text {st }}$ Generation utility facilitation of PV business models. This activity is seen as supporting other business models, and not as stand alone business models. Table 4-3 below provides a brief description of current initiatives that utilities have created to facilitate the development of PV.

Table 4-3. Examples of Utility Programs Supporting Current PV Business Models

\begin{tabular}{|l|c|l|}
\hline Program & Utility & Brief Description \\
\hline Financing & APS & $\begin{array}{l}\text { Building a structure through which banks and lenders offer special } \\
\text { financing or refinancing to solar customers (e.g., APS pays the PV } \\
\text { rebate directly to the lender and the incentive is used to buy down the } \\
\text { interest rate or to re-amortize the loan). }\end{array}$ \\
\hline Financing & PSE\&G & $\begin{array}{l}\text { Proposing to lend capital to end-users and solar developers for 40\%- } \\
50 \% \text { of the project cost, which is repaid over 15 years with S-RECs at } \\
\text { a rate of 12.11\%. S-RECs are valued at their floor price or current } \\
\text { market price, whichever is higher. }\end{array}$ \\
\hline partnership & NSTAR & $\begin{array}{l}\text { Aligning with Evergreen Solar to lower the overall cost of solar } \\
\text { generation by promoting standardized systems installed by pre- } \\
\text { approved solar contractors. }\end{array}$ \\
\hline $\begin{array}{l}\text { REC } \\
\text { Database }\end{array}$ & Xcel Energy & $\begin{array}{l}\text { Partnering with Pioneer Solutions to develop a software application to } \\
\text { view and track RECs for compliance and trading purposes. }\end{array}$ \\
\hline Feed-in Rate & We Energies & $\begin{array}{l}\text { Offering a feed-in tariff of 22.5 } \phi / k W h \text {. Eligible PV systems must be } \\
\text { between 1.5kW and 100kW, and customers must enroll for a 10-year } \\
\text { contract. }\end{array}$ \\
\hline
\end{tabular}

\subsubsection{Arizona Public Service: Financing}

APS is building a structure through which banks and lenders offer special financing or refinancing to solar customers. For example, APS would pay the PV rebate directly to the lender and the incentive would be used to buy down the interest rate or to re-amortize the loan. 
The goal of APS's financing program is to capture the consumer market that wants solar for the financial reasons, not simply because it is a good environmental choice. APS has done significant $R \& D$ to understand its customers' needs, and is taking a national leadership role amongst utilities that promote PV installation to customers.

Through this program, homeowners can understand the economic savings of PV as it is built into their mortgage. The lender accepts a deferred payment of the amount of the rebate from APS, as the mortgage is signed before the PV system is installed.

\subsubsection{Public Service Energy Group: Financing ${ }^{10}$}

Different from APS's program, Public Service Energy Groupd (PSE\&G) would invest $\$ 100$ million over two years to help finance the installation of solar systems for customers in its service territory. Capital would be lent to end-users and solar developers for $40 \%-50 \%$ of the project cost, which would be repaid over 15 years with S-RECs, at a rate of $12.11 \%$. PSE\&G would be repaid in S-RECs, the "currency" of the solar market in New Jersey, which are valued at their floor price or current market price, whichever is higher.

PSE\&G's financing program is awaiting approval from the New Jersey Board of Public Utilities, but the initiative could fulfill up to $50 \%$ of the solar requirements for the New Jersey RPS in the utility's service area for the years 2009 and 2010, or 30 MW of capacity through 2010 . The program would be paid for through funding currently earmarked for renewable energy programs.

\subsubsection{NSTAR: Technology Partnership}

NSTAR has partnered with Evergreen Solar, the manufacturer of the low-cost String Ribbon solar panels. The program seeks to grow solar power installations, in response to customer demand, in the Eastern Massachusetts region (service territory of NSTAR). Through this partnership, NSTAR hopes to make solar installations more accessible and affordable by raising the awareness to its customers of solar options. The utility is exploring whether or not economies of scale can be gained in a vendor model similar to the existing energy efficiency process. For example, NSTAR contracts vendors to respond to customer home energy efficiency audit requests. It may be possible to provide the same service for solar-related home audit requests as solar becomes more prominent in the state.

By partnering with Evergreen, NSTAR can become more knowledgeable about solar and be better equipped to deliver on customers needs. The challenge in Massachusetts is that solar generation is still an expensive alternative to other forms of generation. There are rebate programs in place to help lower the cost and these programs will be critical in helping to develop the PV marketplace.

\footnotetext{
${ }^{10}$ Not reviewed yet by PSE\&G.
} 


\subsubsection{Xcel Energy: REC Database}

Xcel Energy has worked with Pioneer Solutions to roll out a comprehensive database that creates a centralized, flexible system that tracks vintage, source, type, and initial value of each REC using first-in-first-out (FIFO) accounting. The initiative is driven by the fact that trading markets are slow to develop due to the absence of a real-time tracking system. Xcel Energy expects that the states in which it operates will now create REC markets its customers can participate in, along with Xcel.

The goal of the database is to track RECs throughout the utility's eight-state service territory and compile them in a database to manage RPS compliance and potential trading. Xcel Energy is looking to create value by creating a system through which "credible and easily audited REC transactions" can take place. Given that states around the U.S. continue to pass RPS requirements, Xcel Energy is positioning itself to capitalize on the development of future REC markets.

\subsubsection{We Energies: Feed-in Rate}

We Energies' feed-in rate is more similar to solar rebates seen in Europe. The utility offers a purchase rate of $\$ 0.225 / \mathrm{kWh}$ for $100 \%$ of the solar power generated, and the customer gets a bill credit or receives a check when the accumulated amount exceeds $\$ 100$. A second meter is required for the program, which costs $\$ 2.50$ per month for timeof-use customers and $\$ 1.00$ per month for all other customers generating $\leq 40 \mathrm{~kW}$. Eligible PV systems must be between $1.5 \mathrm{~kW}$ and $100 \mathrm{~kW}$, and customers must enroll for a 10 -year contract and sign a standard interconnection agreement. Customers can leave the program with 60 -days notice.

The feed-in rate is part of We Energies' Energy For Tomorrow "green pricing" program supply mix, which aims to increase Renewable Energy resource use for generating electric power and gives customers the choice to invest in helping the environment. The utility gets national recognition for being a leader in the renewable energy field and is able to increase customer satisfaction.

In addition to utility programs that help facilitate current business models, there are a few cases of utility ownership that could pave the way for greater involvement in distributed $\mathrm{PV}$ and a more active role either in ownership or control of PV systems (

Table 4-4). This type of activity falls into our definition of $2^{\text {nd }}$ Generation business models as they include utility ownership.

Table 4-4. Examples of Utility PV Ownership

\begin{tabular}{|l|c|l|}
\hline Program & Utility & Brief Description \\
\hline $\begin{array}{l}\text { Customer- } \\
\text { sited PV }\end{array}$ & SDG\&E & $\begin{array}{l}\text { As part of its sustainable communities program, the utility is installing } \\
\text { PV systems at customer-sites on the utility side of the meter. The } \\
\text { program was approved by regulators and SDG\&E has } \$ 4.3 \text { million per } \\
\text { year. SDG\&E is working with the LEED certifying body so that utility's } \\
\text { PV systems can help the building owner achieve LEED status. }\end{array}$ \\
\hline
\end{tabular}




\begin{tabular}{|l|l|l|}
\hline Solar Shares & SMUD & $\begin{array}{l}\text { SMUD is developing a grid-sited 1MW PV system which would allow } \\
\text { ratepayers to buy "shares" in it through a surcharge on monthly electric } \\
\text { bills. The program aims to attract homeowners or commercial } \\
\text { customers that want solar, but cannot install it because they rent, have } \\
\text { shading issues, or do not have access to up-front capital. }\end{array}$ \\
\hline $\begin{array}{l}\text { Services } \\
\text { (with } \\
\text { ownership } \\
\text { option) }\end{array}$ & Austin Energy & $\begin{array}{l}\text { Considering a program to lease land to project developers. The } \\
\text { developer would build a PV or concentrating solar system and then } \\
\text { utilize/monetize the tax benefits, perhaps benefiting from Austin's } \\
\text { access to low cost tax-exempt debt, after which the developer may } \\
\text { have the option to transfer the ownership to Austin Energy. } \\
\text { Additionally, Austin Energy is considering prepayment options as well } \\
\text { as possible lease arrangements. }\end{array}$ \\
\hline
\end{tabular}

\subsubsection{San Diego Gas \& Electric: Customer-sited PV}

San Diego Gas \& Electric's (SDG\&E) Sustainable Communities Program encourages sustainable building practices in the San Diego area while advancing the utility's electricity delivery system. The program:

1. Provides cash incentives for sustainable building projects,

2. Integrates utility-owned clean generation systems within sustainable buildings, and

3. Creates local showcases that serve as models for other projects.

In terms of siting new clean energy systems, the program works in the following way: systems are installed, owned, maintained, and operated by SDG\&E. All design, installation, and maintenance work is contracted out. Participants "host" generation systems by leasing roof space to SDG\&E, generally for a 10 year period, with two possible five-year extensions. The clean energy system is connected to the utility side of the meter and the electricity flows right into the grid; there is no net metering and no effect on the customer's electricity bill. The building owner can use presence of clean energy system in/on the building toward Leadership in Energy and Environmental Design (LEED) credits (following USGBC credit interpretation) and Collaborative for High Performance Schools (CHPS) points.

The program has a $\$ 4.3$ million capital budget approved by regulators. The investments made under this program are rate-based and were submitted as part of electricity T\&D testimony in the 2004 Cost of Service Filing. Clean energy systems (all PV to date) are strategically selected throughout SDG\&E's service territory. Three installations were completed as of October 2007, with a total installed capacity of $190 \mathrm{~kW}$. Over $1 \mathrm{MW}$ is expected to be installed by the end of 2008 .

\subsubsection{Sacramento Municipal Utility District: Solar Shares}

Under Sacramento Municipal Utility District's (SMUD) program, a solar contractor will build, own, and operate a $1 \mathrm{MW}$ system within SMUD service territory. SMUD will buy all power produced by the system under a PPA and resell power to customers at a subsidized price. Instead of offering rebates for customer owned system, SMUD is 
reducing the price of the solar electricity. Customers will buy blocks of power from the system (e.g., representing .5 or $1 \mathrm{~kW}$ of capacity) for a fixed monthly price. The customer will have a "virtual PV system" that acts like a customer-owned system such that the customer will have net billing with $\mathrm{kWh}$ generation matching output of real system and a fixed monthly payment, similar to financing a rooftop system. SMUD estimates that it can service 900 customers with this offering (assuming a mix of small, medium, and large customers).

The goal of the Solar Shares program is to makes solar available to all customers, including those that cannot or choose not to own their own PV system. For the utility, the program helps SMUD meet aggressive RPS and solar requirements by connecting more solar to the grid for less utility investment compared to customer-sited PV systemseconomies of scale lowers installation cost and federal tax credits are maximized since solar developers can take full 30\% versus $\$ 2 \mathrm{k}$ cap for residential customers. Finally, it demonstrates a sustainable business model that can be expanded in the future and emulated elsewhere, ultimately accelerating PV deployment by reducing costs and developing new markets.

\subsubsection{Austin Energy: Services Agreement}

Similar to other utility programs mentioned above, Austin Energy's services agreement approach is in its planning stages. The idea is similar to a relatively new structure in the wind industry, referred to as a "services agreement", which sometimes involves prepayment for future power deliveries as a way to tap into the municipality's low-cost taxexempt debt, as well as the private developer's access to federal tax benefits. In this case, Austin may lease the land to a developer and has the opportunity to own the solar system in the future. The developer would build a PV or concentrating solar system and then utilize the tax benefits, after which the developer would have the option to transfer the ownership to Austin Energy.

This business model helps Austin Energy meet the state's RPS requirement, while facilitating third-party ownership of solar projects. Austin Energy is still considering prepayment options as well as possible lease arrangements.

\subsubsection{Innovative State Programs Encouraging Current PV Business Models}

The final piece in this section briefly examines what states have done to accelerate PV adoption and new business model creation. While the majority of states require net metering and interconnection and some offer financial incentives for solar investment, a handful of states are creating additional programs and/or mandates to further stimulate PV market growth. States see the PV industry as a driver of economic growth and energy stability, and while only a few programs exist thus far, this could be an indication of growing support for PV at the state-level. Table 4- illustrates the initiative a few states have taken to promote solar development. 
Table 4-6. Innovative State PV Programs

\begin{tabular}{|l|l|}
\hline California & $\begin{array}{l}\text { A new home builder mandate is part of SB1, the Million Solar Roofs bill. } \\
\text { The bill requires that all builders of single-family home developments (>50 } \\
\text { homes) offer solar power as an option. }\end{array}$ \\
\hline Nevada & $\begin{array}{l}\text { In 1995, the Federal government established a Solar Enterprise Zone } \\
\text { (SEZ) in an area of southern NV. The DOE identified the SEZ as a } \\
\text { preferred civilian use of the area that includes the former Nevada Test } \\
\text { Site. The ultimate goal was to deliver 100MW of solar power to the state. }\end{array}$ \\
\hline New Jersey & $\begin{array}{l}\text { A solar REC market was developed as part of the state's Clean Energy } \\
\text { Program. Individuals and businesses can finance their solar installations } \\
\text { by trading an S-REC once the system generates 1 MWh. Utilities can } \\
\text { purchase S-RECs to meet the required RPS. }\end{array}$ \\
\hline Washington & $\begin{array}{l}\text { Solar PV Feed Law pays 15 } 4 / \mathrm{kWh} \text { for electricity generated by solar } \\
\text { panels, and if the panels are manufactured in Washington, a 54 } \phi / \mathrm{kWh} \\
\text { payment. }\end{array}$ \\
\hline
\end{tabular}

\subsubsection{Observations}

The current and emerging business models discussed in this section almost completely fall within the 0 and $1^{\text {st }}$ Generation of PV business model evolution. Much of the innovation and change taking place with current business models is concerned with creating a more efficient, streamlined, and mature delivery channel to the customer. These are important steps in widening the customer base and driving down cost.

As this study progressed, it became apparent that the ownership attribute remained a key factor in defining future business models, but that the characteristic of application was not critical. Instead, the question of who controls the PV system became a defining factor of future business models; thus, future business models are characterized in the next section by ownership and control. As discussed in the Future Business Models section below, we assume that as the PV supply chain matures, the application (e.g., where the system is installed) will become less important than who controls the system and how.

The next section on Future Business Models discusses the evolution to $2^{\text {nd }}$ Generation business models that more fully incorporate PV as part of the electric supply and distribution infrastructure. One of the significant gaps between the $1^{\text {st }}$ and $2^{\text {nd }}$ Generation business models, which will be explored in the next section, is the use of advanced controls and combining PV with other distributed resources and loads. As shown in this section, this type of activity is almost exempt from today's business models. In addition, while utility control and ownership is negligible today, it is explored in the next section. 


\subsection{Future Business Models}

\subsubsection{A Long-term Vision for PV}

In developing future business models for PV, it is necessary to envision the long-term future for the PV marketplace. This helps to identify business models that will be:

- Successful in growing PV markets in the near to medium term, and

- Most capable of addressing the challenges that will arise from increased market penetration of $\mathrm{PV}$.

Looking forward 10 to 20 years, there is a strong case to be made that PV in distributed applications, primarily customer-sited, will become an inevitable and significant component of the electricity sector, especially if forecasted PV cost reductions materialize. The long-term vision is one where PV has passed a "tipping point", beyond which PV is considered competitive with retail power supplied by the grid (Figure 4-10). PV will be competitive when a large segment of electric customers considers the overall value proposition from PV to be competitive with grid power. This will move PV customers beyond so-called early adopters into what is sometimes called the early majority, a large segment of consumers that adopt the technology during a period of rapid market penetration. ${ }^{11} \mathrm{PV}$ may also become competitive for large-scale, centrally-sited PV (e.g., grid-sited), but in this vision, the focus is on distributed PV, where it has the greatest value and greatest implications for grid operations. ${ }^{12}$ For PV to be competitive, it is not necessary for it to have a levelized cost of electricity below the average retail grid power price or even a time-of-use price. There are other attributes for which there is demand and for which there is increasingly real economic value, such as carbon avoidance, other environmental benefits, and increased reliability. New business models can help unlock this value.

\footnotetext{
${ }^{11}$ Geoffrey Moore, Crossing the Chasm, HarperBusiness, 1991.

${ }^{12}$ Large-scale PV systems deployed on the grid will, in the absence of energy storage, behave a lot like peaking plants, and are not the focus of this analysis.
} 
Today

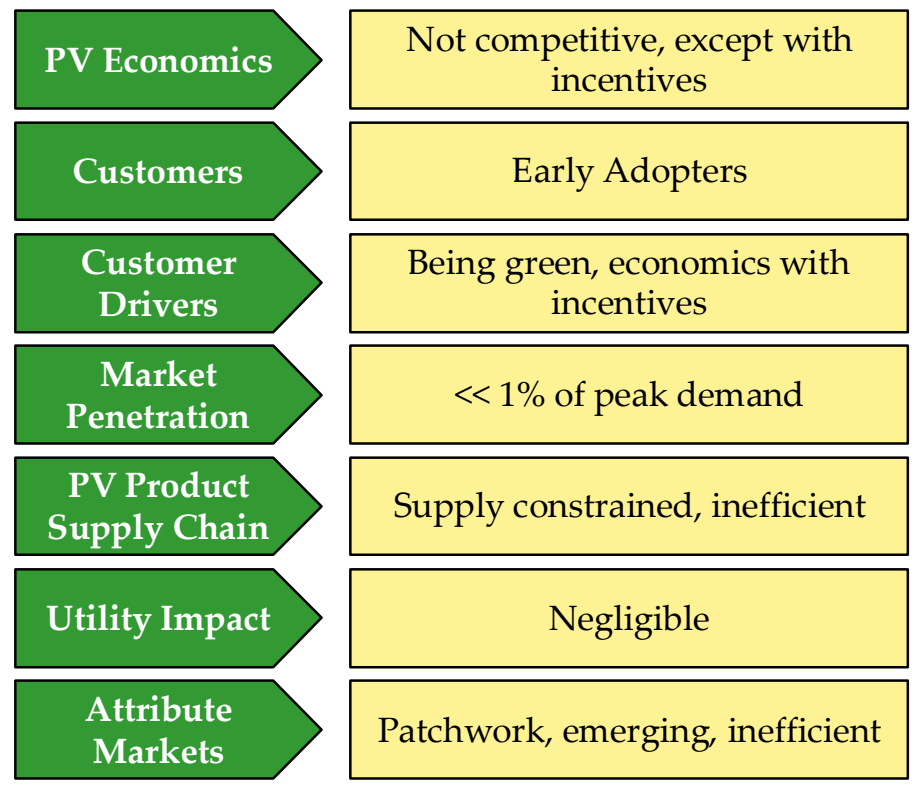

Future Vision

Competitive, especially if attributes are properly valued

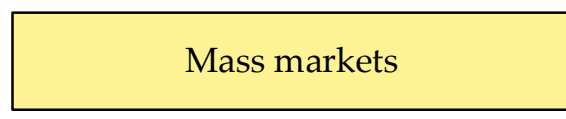

Fundamental economics, enhanced energy services

$10-15 \%$ of peak demand

Unconstrained, streamlined

Considerable (revenue erosion, grid operations, planning)

National (or well coordinated), efficient

Figure 4-10. A future vision for PV

Reaching the point of wide-scale competitiveness with grid power may come sooner, as a result of specific breakthroughs in technology, or later, as a result of the steady march down the cost curve. In either case, it is assumed that the PV supply chain is able to ramp-up capacity to supply the market demand.

Because the resource potential for PV is effectively unlimited (i.e., compared to electricity demand), and PV can be sited virtually anywhere and at any scale, the longterm vision for PV is one in which PV is a major component of electricity supply. Moreover, as the benefits to society and ratepayers of PV deployment become greater, policymakers and utility regulators can be expected to take action to facilitate widespread adoption of the technology. This has significant implications for key stakeholders, especially the utility and the end-user. In unbundled power markets, wholesale power suppliers and transmission companies may also be impacted in a meaningful way as more and more demand is met with distributed resources, which could lead to stagnant, if not decreasing, demand for wholesale power and related transmission service.

Table 4-5 summarizes the main implications to key stakeholders of such a long-term vision. Consistent with the overall approach in this report, this section focuses on the ownership and operation of the PV systems, and not on the PV product supply chain. Over time, the PV equipment supply chain can be expected to look like other equipment supply industries (emergence of a few large suppliers, similar margins, ready access to financing, standard product offerings, and overall competitive structure). Conversely, stakeholders that are involved in the ownership and operation of PV systems will be participating in a major reconfiguration of the traditional power supply business. This is where innovation and disruption in "business as usual" will occur, and where there is potential to unlock the value of PV. 
Table 4-5. Implications of Widespread Distributed PV Deployment on Key Stakeholders

\begin{tabular}{|c|c|}
\hline Stakeholder & Implications \\
\hline End-user & $\begin{array}{l}\text { PV system: } \\
\text { - Is cost-effective alternative to the grid } \\
\text { - } \quad \text { Provides improved reliability (over grid) } \\
\text { - Generates a range of value streams (driven in part by environmental } \\
\text { - } \text { and climate change policy) } \\
\text { Is part of a bundle of new technologies to improve energy service at } \\
\text { distribution system automation, "smart homes", plug-in hybrid } \\
\text { vehicles) }\end{array}$ \\
\hline System Owner & $\begin{array}{l}\text { - PV system output has multiple value streams that can make it } \\
\text { competitive in the market relative to grid power } \\
\text { - Owner needs to be able to identify and capture multiple PV value } \\
\text { streams }\end{array}$ \\
\hline $\begin{array}{l}\text { Distribution } \\
\text { Utility and } \\
\text { Vertically } \\
\text { Integrated } \\
\text { Utility }\end{array}$ & $\begin{array}{l}\text { - High degree of PV market penetration creates: } \\
\circ \text { Reduced throughput leading to revenue loss under traditional } \\
\text { tariff structures } \\
\circ \text { Need for control of PV systems and/or new distribution system } \\
\text { architectures to ensure safety, operational integrity and reliability } \\
\text { of the distribution grid } \\
\text { - In addition, new technologies used in conjunction with PV could } \\
\text { radically change utility operations and product/service offerings to } \\
\text { customers (low-cost energy storage, distribution system automation, } \\
\text { "smart homes", plug-in hybrid vehicles) }\end{array}$ \\
\hline $\begin{array}{l}\text { Wholesale } \\
\text { Generator }\end{array}$ & $\begin{array}{l}\text { - High degree of PV market penetration could provide competition in the } \\
\text { wholesale market to more expensive generating assets }\end{array}$ \\
\hline Regulator & $\begin{array}{l}\text { - Emergence of cost-effective PV and other complementary technologies } \\
\text { creates need for major transformation of how utility industry is regulated }\end{array}$ \\
\hline $\begin{array}{l}\text { Transmission } \\
\text { Company }\end{array}$ & $\begin{array}{l}\text { - High degree of PV market penetration could impact the demand for } \\
\text { transmission services }\end{array}$ \\
\hline
\end{tabular}

\subsubsection{Other Developments and Considerations}

At the same time that the PV industry is making great strides in the deployment of PV using 0 and $1^{\text {st }}$ Generation approaches, significant activities are also occurring outside of the PV industry that have clear implications for long-term PV market penetration. In particular, changes in policy, technology and utility regulation may hold the potential to not only create opportunities to unlock additional value from PV systems, but may simultaneously create more demand for it (Figure 4-11).

Technology developments underway to manage the distribution grid more effectively will have many benefits for distributed generation, including PV. In particular, the development of distribution system automation, the transition to "smart grids," and the deployment of customer- and utility-controlled demand response are all likely to help utilities and others unlock additional value from distributed PV systems. 
Policy trends that create a market for renewable energy, such as Renewable Portfolio Standards or RPS (especially those with solar set-asides) and greenhouse gas emission caps, are gaining momentum at the state and local levels, and may ultimately culminate in much higher average state targets and, eventually, a federal-level policy.

Finally, regulatory changes in some states are altering the way a utility perceives its business. Beyond net metering and interconnection issues, performance-based ratemaking (in which incentive benchmarks, rather than budgets, determine cost recovery) and revenue decoupling mechanisms (in which rates are determined as a function of service delivery rather than as a strict return on hard assets) are being implemented to encourage energy efficiency, conservation, and renewable energy. Given these types of changes, the ability of a utility to realize revenue from rates that are based in part on reconfiguring its grid and altering its customer support to integrate PV will have obvious benefits for the further increase of distributed PV. In addition, some utilities have experimented with tariff structures to encourage desired consumer behaviors and the deployment of new technologies. For example, variations of time-of-use pricing can be very beneficial to PV economics. Also, adoption of transmission congestion pricing should have a beneficial impact on distributed PV, as the market value of distributed generation will be made plain by the congestion prices. These regulatory actions are increasingly being driven by the desire to encourage conservation or greenhouse gas reductions.

\begin{tabular}{|l|}
\hline \multicolumn{1}{|c|}{ Technology } \\
\hline - Development and \\
deployment of distribution \\
automation technologies \\
- Transition to "smart grids" \\
- Continued development and \\
deployment of other \\
distributed generation \\
technologies \\
- Development and \\
deployment of plug-in hybrid \\
vehicles (implications for grid \\
operations, load growth and \\
battery technology \\
development) \\
\hline
\end{tabular}

\begin{tabular}{|l|}
\hline Policy \\
\hline • Further development of \\
Renewable portfolio \\
standards (increasingly with \\
solar set asides) \\
- Greenhouse gas emission cap \\
\& trade programs and other \\
climate change initiatives \\
- State-level economic \\
development initiatives \\
- Growth of state solar energy \\
initiatives and system \\
benefits charge funds
\end{tabular}

\begin{tabular}{|l|}
\hline \multicolumn{1}{|c|}{ Regulatory } \\
\hline - Performance-based \\
ratemaking \\
- Revenue decoupling to \\
encourage energy efficiency \\
and conservation \\
- Tariff structures optimized \\
for PV and other distributed \\
generation \\
- Demand response programs \\
(customer and utility \\
controlled) \\
\end{tabular}

Figure 4-11. Ongoing energy sector developments affecting distributed PV markets

\subsubsection{Utility Structure and Core Competencies}

To understand how electric utilities will become more involved in distributed PV as a business opportunity, it is important to review the basic structure of the electric utility industry and to understand utility core competencies. Figure 4-12 shows a basic electric utility value chain, from fuel supply to end-user. The picture is complicated because some states have unbundled (restructured) their electric utilities, and in these instances, each of the basic functions shown in Figure 4-12 is performed by separate companies. 
For the purposes of this report, the key element to consider is that restructuring has separated the basic functions of generation, distribution, and retail power sales (e.g., transmission may still be owned by distribution companies). In these cases, the companies that own the wires no longer own generation, and the retail sale of electricity is opened up to competition. The distribution (wires) companies, which are still subject to state regulation, also serve as "default service providers", selling electricity to customers that do not switch to competitive energy suppliers.

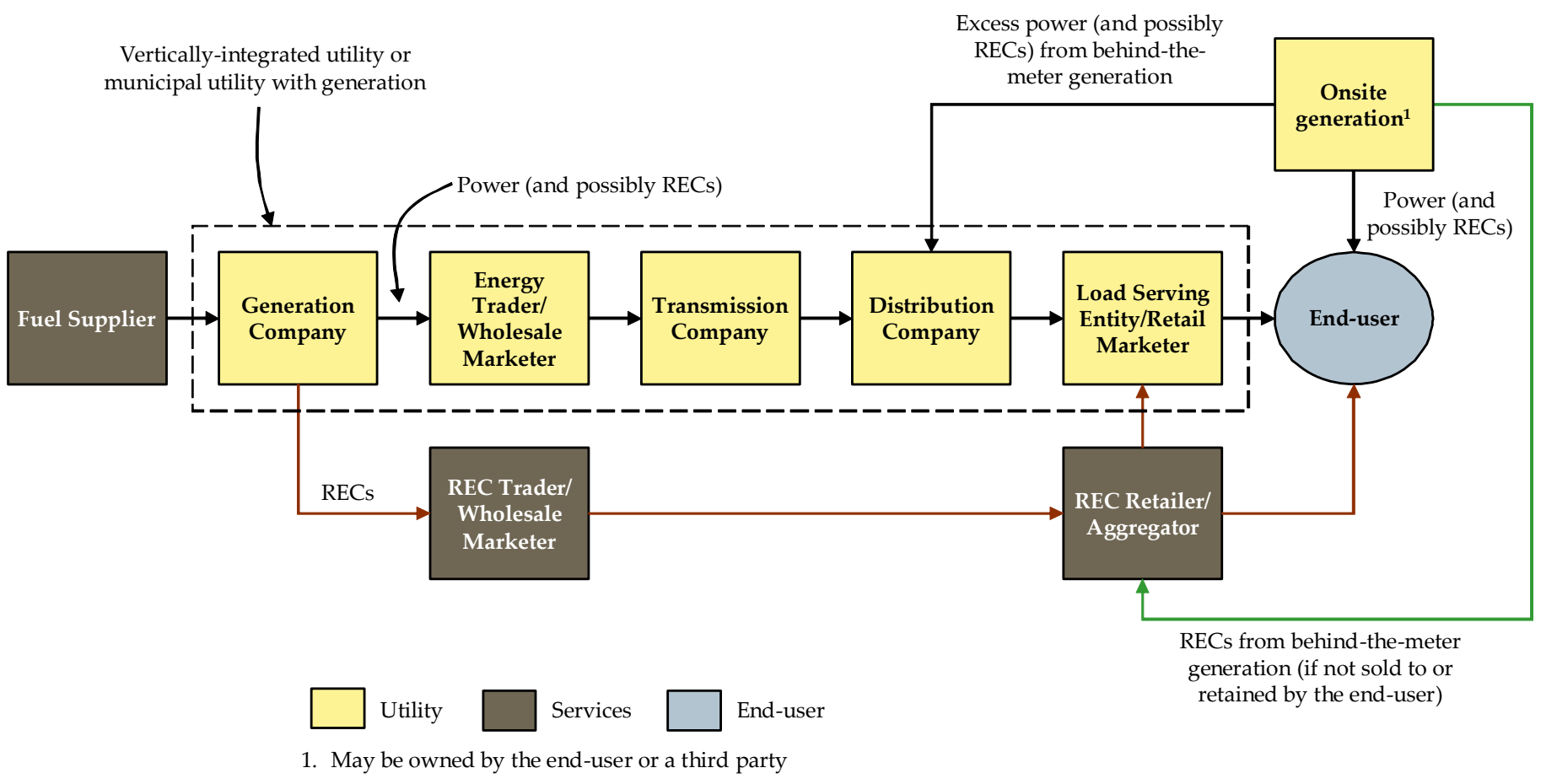

Figure 4-12. Simplified electric power value chain

Large municipal utilities (i.e., that own generation) and vertically integrated investorowned utilities (IOUs) still control the entire value chain. As such, they own a significant portion of the capacity used to meet their load. These assets are in the "rate base". However, even with vertically integrated IOUs, the wholesale power markets are competitive in that IOUs cannot simply add generating capacity to meet their demand growth. Instead, they must competitively procure this capacity. In this case, the power purchase agreements are typically treated as recoverable cost and thus utilities are not permitted to earn a return.

IOUs are subject to regulation by the state utility commission, whereas municipal utilities generally are not. In restructured markets, utility regulators generally focus on the distribution companies, while wholesale generation companies and load serving entities are generally considered unregulated businesses. Smaller municipal utilities (i.e., the majority of municipal utilities that do not own generation) resemble distribution companies but also act as the load serving entity. 
Unbundled power markets present some unique issues for distributed PV, in particular, how different value streams can be captured when there are several different entities along the electric power value chain. For example, since a distribution company does not generally own generation, value that PV has for offsetting the need for additional fuel or generation capacity, is not easily captured. Conversely, to the extent that the value of PV can ripple up the value chain, a vertically integrated entity can internalize all of those benefits. Also, distribution companies in unbundled markets may be barred from owning generation, but future PV business models may center around utility ownership of PV. Thus, regulatory changes may be needed to address this and other issues.

The previous discussion is important because it has implications for the regulatory changes that may be required as utilities become more deeply involved in the PV market. Nevertheless, whether talking about vertically integrated vs. unbundled markets, or IOUs vs. municipal utilities, the main parts of the value chain that will be impacted are distribution and retails sales. Thus, when this report refers to "utilities", it is primarily with these functions in mind.

Under the current regulatory structure, utilities (and other stakeholders in the electric power value chain) have a lot to lose from high levels of distributed PV market penetration. Nevertheless, utilities possess a range of core competencies and attributes that they can leverage for new PV business models. While they can vary depending on the type of utility, as described above, they generally fall into three categories (see Figure 4-13): asset management and investment, customer service, and system operation.

So while distributed PV may initially be viewed as a threat, it is also clearly an opportunity, and this is expected to be the central issue going forward as new PV business models are developed. 


$\left.\begin{array}{|c|}\text { Asset } \\ \text { Management \& } \\ \text { Investment }\end{array}\right\rangle \begin{aligned} & \bullet \text { Manages an asset-intensive business } \\ & - \text { Accustomed to making large, long-term capital investments } \\ & \bullet \begin{array}{l}\text { Creditworthiness } \\ \text { Has real estate that could be used for PV installations (free of } \\ \text { charge) }\end{array}\end{aligned}$

\begin{tabular}{|c|c|}
\hline $\begin{array}{l}\text { Customer } \\
\text { Service }\end{array}$ & $\begin{array}{l}\text { - Has access to customers } \\
\text { - Manages customer relationships } \\
\text { - Credibility with customers (e.g. for maintenance) } \\
\text { - Mounts marketing campaigns to raise customer awareness of } \\
\text { new offerings }\end{array}$ \\
\hline
\end{tabular}

$\left.\begin{array}{|c|l|}\hline \text { System } \\ \text { Operations }\end{array}\right\rangle \begin{aligned} & - \text { Performs O\&M on widely dispersed assets } \\ & - \text { Ensures safety (for employees and customers) } \\ & \text { Knows the distribution grid better than anyone (best } \\ & \text { positioned to locate PV in order to extract maximum value) }\end{aligned}$

Figure 4-13. Utility core competencies and attributes to leverage for new PV business models

\subsubsection{Maturation of the PV Value Network}

As discussed in Section 4.2, the emphasis in PV markets up to now has been largely on the PV product supply chain, and more recently, on reducing hassle for customers and third-party ownership of customer-sited PV. These areas continue to be the main focus of investment, as the industry attains large-scale status in manufacturing, product delivery, and installation. Over the next 5-10 years, one can expect these aspects of the PV value network to continue to mature and consolidate, and therefore, the PV product supply chain should come to resemble other businesses that supply key building infrastructure, like HVAC equipment. While there will still be room for customization, it is expected that to a large extent, the PV product supply chain will become more streamlined and efficient, and PV products will be more standardized. Similarly, other aspects of the PV value network will become "commoditized", such as financing.

Table 4-6 summarizes the expected evolution of the various elements of the PV value network.

Table 4-6. Maturation of the PV Value Network

\begin{tabular}{|l|ll|}
\hline $\begin{array}{l}\text { Value Network } \\
\text { Element }\end{array}$ & & \multicolumn{1}{c|}{ Trends } \\
\hline $\begin{array}{l}\text { Upstream PV } \\
\text { product Supply }\end{array}$ & - $\begin{array}{l}\text { Increased scale of manufacturing to bring down costs } \\
\text { Improved ability to incorporate product innovations and improvements } \\
\text { into standardized products } \\
\text { Integrator/ }\end{array}$ & - Supply chain will consolidate and become more efficient \\
\hline Installer/EPC & - $\begin{array}{l}\text { Supply chain will consolidate and become more efficient } \\
\text { High-quality installation will become common and fairly non-specialized } \\
\text { (i.e., similar to current HVAC or roofing industry) }\end{array}$ \\
\hline
\end{tabular}




\begin{tabular}{|c|c|}
\hline O\&M & - Non-specialized firms will be able to provide O\&M \\
\hline Monitoring & $\begin{array}{l}\text { System monitoring will become highly automated and integrated with } \\
\text { O\&M provision and become integral to the provision of other services } \\
\text { around the PV system and other energy systems and services }\end{array}$ \\
\hline Financier & $\begin{array}{l}\text { - } \quad \text { Access to financing will be easy and will leverage existing channels } \\
\text { - } \quad \text { Less financing will be required per system given drop in system prices }\end{array}$ \\
\hline $\begin{array}{l}\text { Attribute } \\
\text { Aggregatorl } \\
\text { Marketer }\end{array}$ & $\begin{array}{l}\text { - As attribute markets mature, aggregator/marketers will grow in size and } \\
\text { market will become more liquid and efficient, to resemble other } \\
\text { commodity markets } \\
\text { - This service may increasingly be bundled with other energy products and } \\
\text { services, such as financing, energy management and energy supply } \\
\text { - Large uncertainty is the pace at which the patchwork nature of the } \\
\text { market today will grow and mature to maximize value extraction from } \\
\text { attributes. }\end{array}$ \\
\hline $\begin{array}{l}\text { Project } \\
\text { Developer }\end{array}$ & $\begin{array}{l}\text { For large projects there will still be a role for project developers, } \\
\text { analogous to role played by wind farm developers today } \\
\text { Pure-play developers may not be common as this activity becomes } \\
\text { incorporated with other elements of the PV value network, such as } \\
\text { installation } \\
\text { - For customer-sited projects, the role may evolve into one of a broker, } \\
\text { whereby the broker works with a customer to solicit and evaluate bids } \\
\text { from prospective installers (similar to a real estate agent). }\end{array}$ \\
\hline $\begin{array}{l}\text { Utility } \\
\text { Regulator }\end{array}$ & $\begin{array}{l}\text { - May realize benefit to ratepayers of more widespread PV and take action } \\
\text { to facilitate widespread adoption } \\
\text { Inclusion of PV in rate cases and regulatory hearings will be } \\
\text { commonplace }\end{array}$ \\
\hline $\begin{array}{l}\text { Local } \\
\text { Government }\end{array}$ & $\begin{array}{l}\text { - May have familiarity with applications for PV permits and will have made } \\
\text { adjustments to permit process and building code to facilitate consumer } \\
\text { demand (e.g., standardization across jurisdictions) }\end{array}$ \\
\hline $\begin{array}{l}\text { State \& Federal } \\
\text { Government }\end{array}$ & $\begin{array}{l}\text { - Will reduce incentives considerably given the reduction in system price } \\
\text { - } \quad \text { Remaining incentives are likely to reflect environmental benefits } \\
\text { - } \quad \text { Mechanisms to monetize benefits (e.g., attribute markets) will be } \\
\text { developed in favor of high-cost financial incentives such as rebates }\end{array}$ \\
\hline Utility & $\begin{array}{l}\text { - Increased understanding of and experience with the technology } \\
\text { - See Table 4-5 }\end{array}$ \\
\hline
\end{tabular}

We assume that as the PV supply chain matures, the application (e.g., where the system is installed) will become less important as a defining characteristic of business models than who owns and controls the system. Thus in the new business models section below, the ownership attribute remained a key factor in defining future business models, but the characteristic of application is not longer used, as in the current business models section. Instead the question of who controls the PV system became a defining factor of future business models, thus, future business models are characterized in the next section by ownership and control.

\subsubsection{New PV Business Models}

New business models will become necessary when distributed PV becomes a large enough fraction of total load on the grid, such that it cannot be ignored from the perspective of grid management and utility revenue erosion. As such, new business models will be focused on greater integration and control of PV, potentially bundled with 
other value-added services that may be enabled by so-called "smart grid" technologies. ${ }^{13}$ What will distinguish these new business models from current ones are:

- PV system ownership

- Who pays for the system

- Who receives the value generated by the system

- PV system operation and control

- How to ensure safe, reliable and efficient operation of the grid

- How to maximize value from the PV asset(s)

Of all the stakeholders involved, it is the utility that will have its existing business model disrupted the most, and must therefore adapt its current business model in order to protect and enhance its business. Thus, greater utility involvement is seen as the key to new PV business models.

Three basic types of business models are examined for the future (Figure 4-14), depending on who owns and controls the system. A fourth option, in which the system is owned by the utility but not controlled by the utility, is not consider a viable business model. As will be discussed in more detail below, the success of any of these types of new PV business models will be tightly linked to ongoing technology and market developments in distribution automation and demand response, and may also require significant regulatory changes.

\footnotetext{
${ }^{13}$ For example, on September 26, 2007, FPL Group announced the launch of an initiative to invest up to $\$ 500$ million to create a smart network that will provide its 4.5 million customers with enhanced energy management capabilities. This new program is designed to allow customers to view their energy consumption online every day, in real time, and to enable FPL to develop better energy management programs (FPL Group press release: FPL Group Plans to Boost U.S. Solar Energy Production. JUNO BEACH, Fla., Sep 26, 2007).
} 


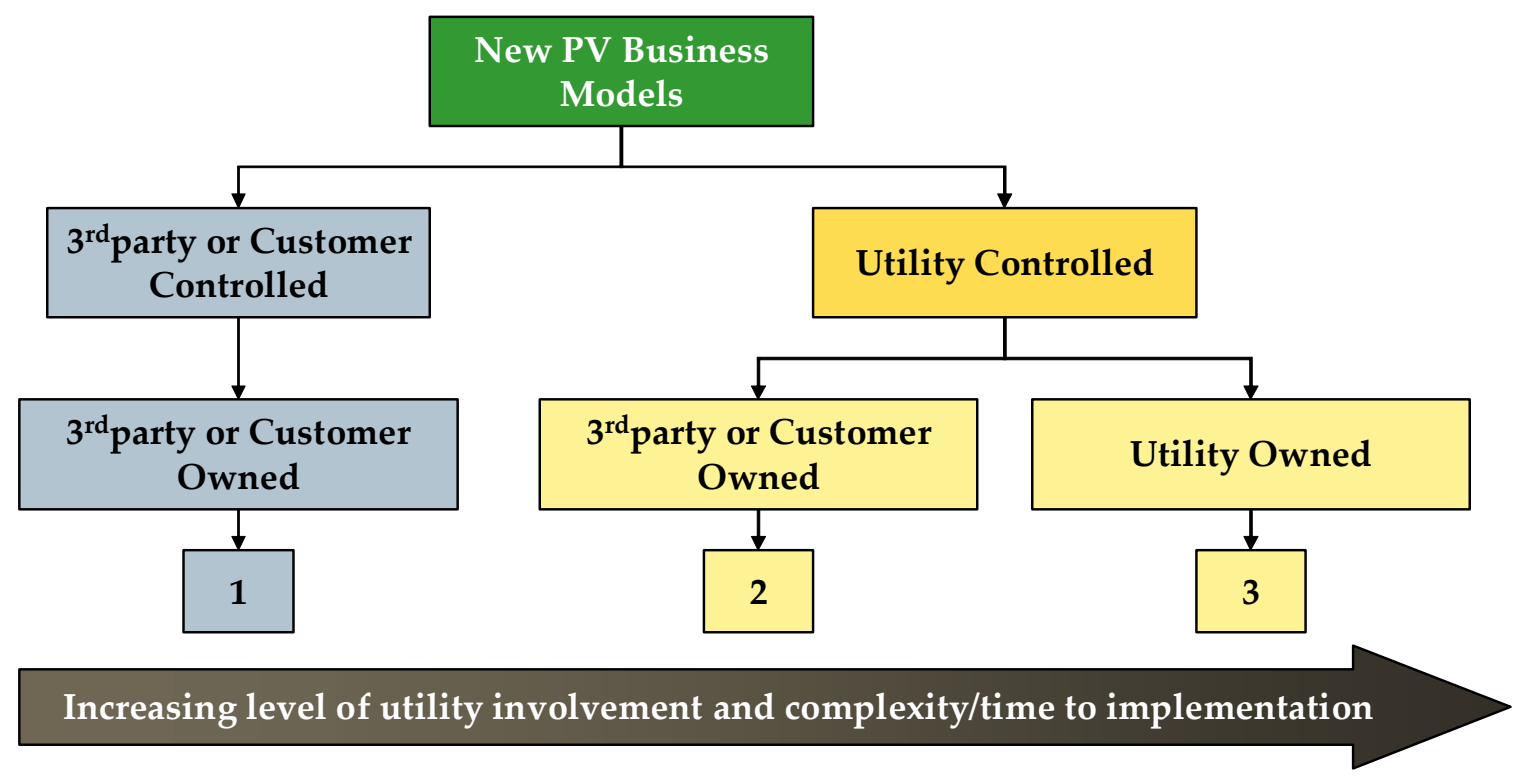

Figure 4-14. New PV business models focused on system ownership and control

From a business model perspective, the combinations above need to be evaluated from two basic positions:

- What are the sources of revenue that support the business model

- What cost savings support the business model

For example, to the extent that there are system-wide benefits, these can generally be thought of as cost savings to the utility (e.g., reduced fuel consumption at central plants due to PV generation, the use of PV on-peak to make the T\&D system more efficient, avoided investments in traditional generation assets). Other benefits may accrue to, or have value for, the end-user. For example, the environmental attributes of PV generation can be sold, producing revenue for the owner of those attributes, or if PV can be made part of a backup system, this service can have value to the end-user.

Depending on the type of business model and regulatory structure, dollars may flow from the utility to the owner/end-user, or vice versa. As highlighted in the DOE Renewable System Interconnection PV Value study, it is worth noting that the largest potential sources of value relate to central generation (both in terms of marginal generation costs and avoided capacity investment costs) and avoided investments in transmission and distribution. The next most valuable are the environmental attributes, driven by policies and regulations to curb criteria pollutants and greenhouse gases. However, the dynamic benefits of distributed PV to the grid (e.g., ancillary services, system losses, system resiliency) are much lower. This suggests that business models built around these lowervalued PV system attributes may not be viable, unless they can also take advantage of the other more lucrative value streams. 


\subsubsection{Third-party/Customer Owned and Controlled PV Business Model}

\subsection{General Description}

In this business model, the customer or a third party controls the PV system as well as owns it. There is also the possibility of customer ownership combined with third-party control. This business model is primarily an extrapolation of current business models and trends (Figure 4-15). The key difference is that additional sources of revenue are captured by the owner, based on various changes to the regulatory and policy regimes, and on the deployment of "smart grid" technologies and energy storage that is integrated with PV system operation.

In this model, the utility role remains mainly one of facilitation - primarily driven by regulatory or policy changes; for example, in the increased use of demand response programs and greater implementation of S-REC markets, like in New Jersey. In this model, the utility pays for value-added products and services obtained from the PV system and is then allowed to recover these costs through traditional rate-making proceedings. In order to encourage this new model, regulators could consider allowing slightly higher rates of return — at least initially—as utilities adopt new practices.

Because an end-user with customer-side PV can generally already take advantage of net metering, the incremental value is expected to be modest. As such, this business model is not driven by the value of additional products and services. Rather, the growth of the PV installed base presents an opportunity for taking advantage of these assets. To the extent that there can be pricing or other signals that promote adoption of PV on certain parts of the grid (e.g., areas with constraints), this can serve to generate the most value possible.

This business model is considered the most likely to become established in the absence of outside influence, as various pieces of current regulation and policy are already in place to enable it in some jurisdictions. For example, PV with battery storage and/or in combination with load management would be able to fit under a demand response program, adding value over just net metering alone. Similarly, S-REC obligations in some states have already established a value for PV's environmental attributes. In addition, the incremental value provided by the PV system in this model is not dependent on having large amounts of distributed PV available. However, some values would certainly not be captured until additional regulations are in place. 


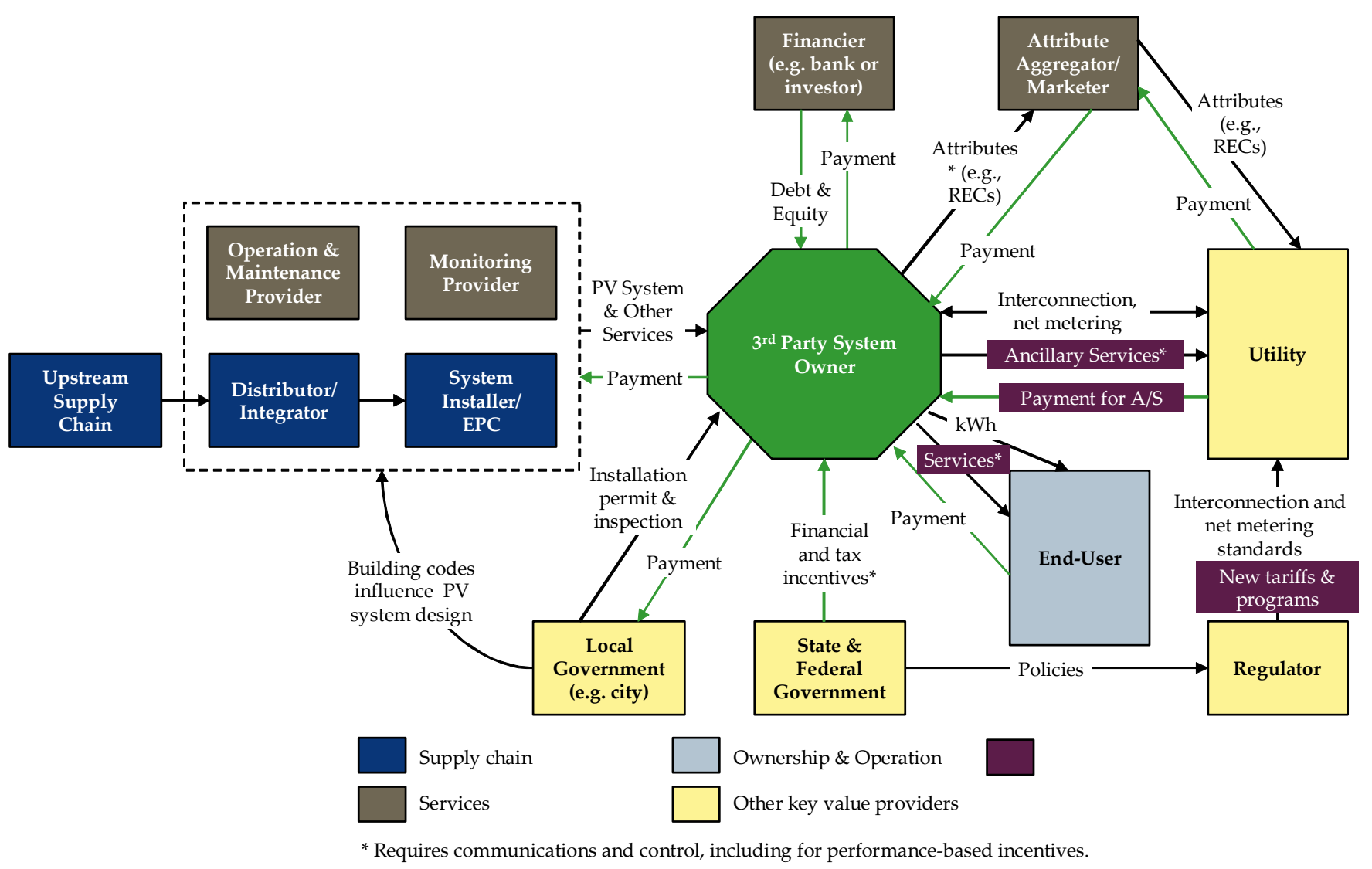

Figure 4-15. Third-party/Customer Owned and Controlled Value Network

The basic model shown above can be altered to show end-user ownership and control by simply replacing the third-party system owner with the end-user, and eliminating the final transaction for $\mathrm{kWh}$ sales. In addition, the supply chain and other services-including O\&M, monitoring, financing and attribute aggregation - are shown separately for consistency with Sections 4.1 and 4.2. However, as discussed earlier, they could be combined in numerous ways, including provision of financing via the integrator or installer. In a similar way, the function of aggregating the attributes generated by the PV system could be performed directly by the utility.

\subsection{Business Model Requirements}

In this structure, the dollars are expected to flow mainly from the utility to the owner, with the regulatory structure making accommodations for this. In this sense the utility's business model would remain largely unchanged, as these transactions would be subject to cost recovery. In some variations (see Table 4-9), activities may result in flows of dollars to the utilities (e.g., for maintenance or distribution wheeling charges). At the macro level, these business models will emerge in cases where overall, the current regulatory structure is maintained, but where the utility is made whole due to lost revenues, and where markets are created for attributes and there is potential allowance of distribution wheeling. It is notable that depending on how regulation plays out (e.g., if utility is made whole or not), this group of business models could lead to significant 
overall revenue erosion for utilities, especially as it results in a decrease in generation and throughput over the system.

Energy storage could further enhance the value of PV to both the utility and the customer. For the customer to benefit directly (i.e., PV as backup), current interconnection standards will need to be changed to allow for the system to continue to operate during a network outage.

Tariffs optimized for PV will also allow the end-user to maximize opportunities for cost savings. These could include time-of-use pricing, real-time pricing, enhanced net metering tariffs, and tariffs that would potentially allow for wheeling of excess generation across the distribution system. Changes to distribution pricing (e.g., locational pricing) may also send signals to end-users to encourage adoption of PV in areas of highest value to the utility.

As the market penetration of PV grows, utilities may be required to raise net metering caps or remove them altogether. Eventually, this may require some reconfiguration of the distribution system to accommodate the high penetration levels of PV. Furthermore, if PV systems are integrated with demand response, and utilities come to rely on this available capacity, utilities will likely seek certain commitments from demand response customers. Thus, it may be necessary to integrate PV systems with other load management options, including demand restrictions, should the customer be unable to meet their commitments.

Since the PV asset is neither owned nor controlled by the utility, the ability to send the appropriate price or other signals to many owners is important to ensuring the fleet of PV systems is of value to the utility. For this, some key technologies include:

- Advanced communications, monitoring and metering, which allow for response to pricing and other signals to maximize value to the end-user. These technologies could allow response to pricing signals for various attributes and could be used to verify system operation and delivery of network services;

- Communications and control technologies that allow third-parties to aggregate PV system output and actively manage systems as a fleet in response to various pieces of information from the grid; and

- Energy storage to firm-up capacity and allow for dispatch of the system, and to enable services to end-users.

Finally, even though the utility does not have control over the PV system in this business model, it might require the right to "see" the location and generation of the system on the grid, as the PV systems operation can impact overall grid operations. Advanced communications, monitoring, and metering technologies already in place could include two-way communication capabilities to provide utilities with basic system operation information. 


\subsection{Variations}

A number of variations on the basic business model described here are possible (see Table 4-7).

Table 4-7. Business Model Variations for Third-party/Customer Owned and Controlled PV

\begin{tabular}{|l|l|}
\hline $\begin{array}{c}\text { Business Model } \\
\text { Variation }\end{array}$ & $\begin{array}{l}\text { In active REC markets for RPS compliance, especially those with solar set- } \\
\text { asides, forward purchases of REC streams could emerge as a viable } \\
\text { business model. Utilities or other entities would cover all or part of the up- } \\
\text { front cost of the system in exchange for a future REC stream. Forward REC } \\
\text { purchase might be able to be rate based. } \\
\text { purchases }\end{array}$ \\
\hline $\begin{array}{l}\text { Distribution-level PSEG has filed a concept similar to this with regulators. } \\
\text { ancillary services } \\
\text { market }\end{array}$ & $\begin{array}{l}\text { With the right regulatory and technological changes, a market for ancillary } \\
\text { services at the distribution level could develop. The utility would pay for such } \\
\text { services, and as the market develops, the utility could grow to rely on it and } \\
\text { incorporate it into system planning. The utility would seek out the least-cost } \\
\text { approach to procuring the ancillary services it needs to operate the } \\
\text { distribution system. Demand response and VAR support are two examples. }\end{array}$ \\
\hline Customer-focus & $\begin{array}{l}\text { PV could become part of a technology package offered to end-users by third } \\
\text { parties, such as energy service companies. PV could be integrated with } \\
\text { energy efficiency performance contracting, energy procurement (in } \\
\text { restructured markets), and building energy management services, including } \\
\text { backup generation. }\end{array}$ \\
\hline $\begin{array}{l}\text { Distribution utility } \\
\text { as network } \\
\text { services provider }\end{array}$ & $\begin{array}{l}\text { This vision of a distribution utility is most likely to emerge in unbundled } \\
\text { markets. In this model, the utility (as the wires company) provides a range of } \\
\text { network services to end users. This would require the decoupling of utility } \\
\text { revenues from energy sales (this could include distribution wheeling). This } \\
\text { model of the utility, if it emerges, could further enable the "customer focus" } \\
\text { business model. Net-metering tariffs would be replaced by the ability of end- } \\
\text { users or third-party owners to sell excess power over the grid to other end- } \\
\text { users. }\end{array}$ \\
\hline
\end{tabular}

\subsection{Challenges}

As discussed above, the value of distributed PV to the operation of the distribution system is expected to be modest. As such, it may be difficult to create new business models centered around these values. Instead, these value streams are likely to be added incrementally to existing business models. Moreover, value streams from distributed PV can be broadly grouped into two categories - operations and planning. In these business models, the utility does not control the timing or siting of PV capacity; therefore, it is difficult for the utility to incorporate deployment of PV into distribution system capital planning, as the ultimate decisions of when and where to site are out of their control. This may result in a sub-optimal grid configuration and will make it more difficult for the utility to incorporate PV into capital planning activities.

In order to at least partially compensate for this issue, the utility could issue RFPs for network services. This would encourage siting in the best locations. The utility may also provide incentives to site in constrained areas to maximize grid value. 
In unbundled markets, there are few ways to address the potential impacts of widespread adoption of PV on retail energy suppliers, wholesale generators, and transmission companies. These companies, however, could take on the third-party ownership role, thereby mitigating impacts on their wholesale business. Still, in the case of very high PV deployment, the potential exists for there to be stranded generation assets, in both vertically integrated and restructured markets.

If the customer/third-party controlled and owned business model becomes widespread, the distribution grid must be re-engineered to be highly responsive to changes in PV operating profiles (e.g., extremely localized power fluctuations), either due to transient changes in sunlight availability or to decisions taken by the owners, because the utility will not control the PV systems. An issue that will arise is the degree to which owners will be "free to choose" how to operate their systems. For example, if a customer chooses to participate in a demand response program, they might be obligated to respond to utility signals.

\subsubsection{Third-party or Customer Owned and Utility Controlled PV Business Model}

\subsection{General Description}

This business model is somewhat similar to those described above, in that they seek to achieve similar objectives (Figure 4-16). The key difference is that greater utility involvement in the operation and control of the systems is contemplated as a way to increase the value of the assets. Like the customer controlled business model described above, regulatory and policy regimes will need to change - though more significantly here - to allow the utility to reach behind the meter where the PV system will reside. In this case, the customer will not respond to price signals because the utility is controlling the PV system, at least to some extent. This business model will also require the deployment of "smart grid" technologies and would be enhanced by energy storage.

This business model may work best where aggressive demand response or other similar programs are being pursued or where high penetration of PV systems may pose serious grid control and operations issues. Under those circumstances, direct utility control-for example, to allow the utility to curtail PV system operation to maintain grid stabilityinstead of a complicated market for such services, may be preferable because the utility is assured response as it controls the asset as opposed to relying on optional response to price signals.

In this model, the utility would still pay for value-added products and services, and would then be then allowed to recover these costs through traditional rate-making proceedings. To the extent that PV systems provide a service and create value (e.g., avoid costs) for the utility, this would be factored into the cost of recovery calculation

This business model is expected to evolve more slowly given the additional regulatory changes required to permit utility control behind the meter. Additionally, distributed PV 
needs to exist at a significant scale in order for a utility to find value in controlling it. For example, the distributed PV installation would have value to the utility proportional to its capacity to substitute for generation, capacity, and transmission and distribution (T\&D) investments.

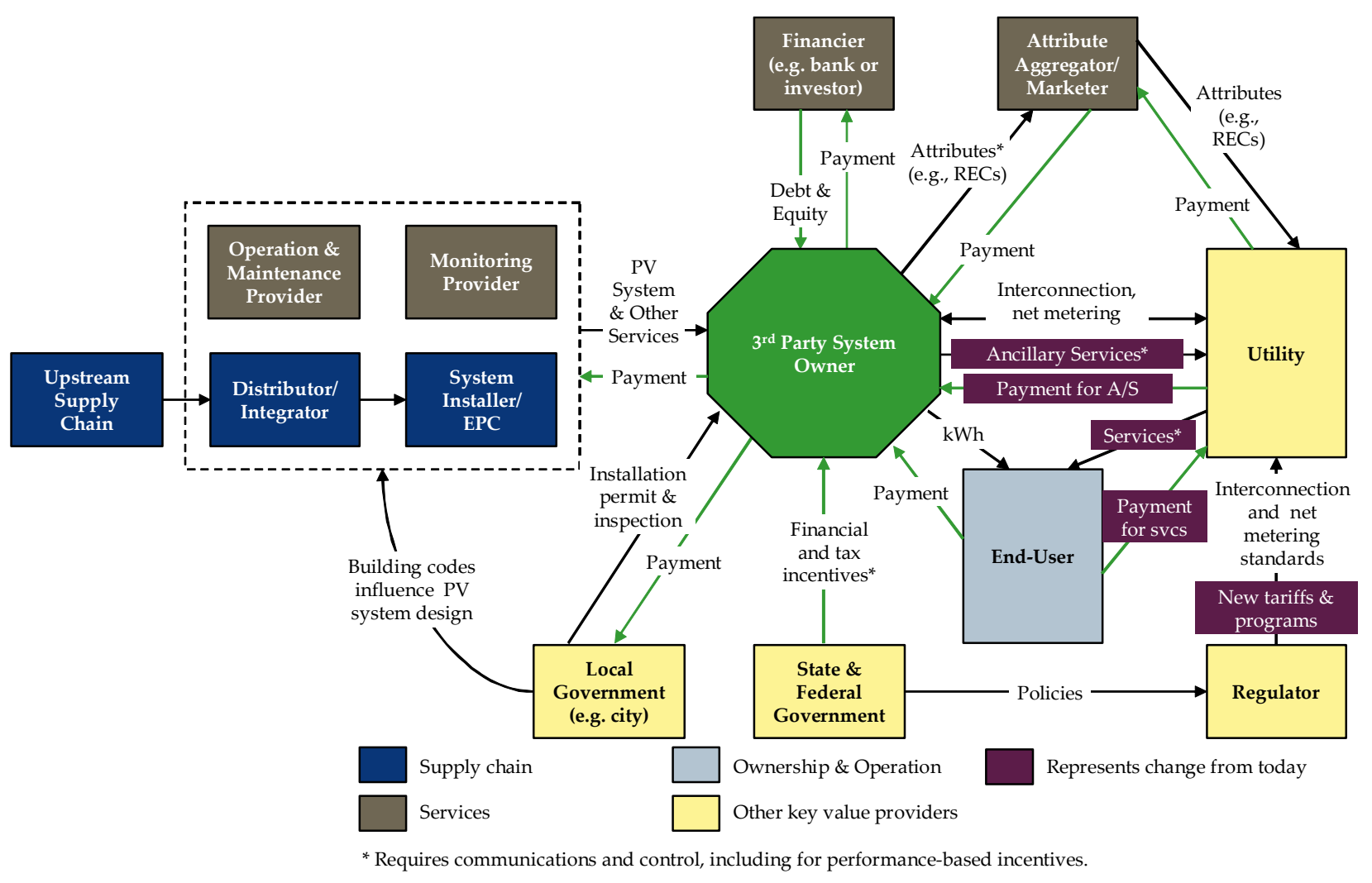

Figure 4-16. Third-party/Customer Owned and Utility Controlled Value Network

As discussed in the section above, this diagram could represent the end-user as the owner by simply replacing the third-party system owner with the end-user, and disregarding the transaction for kWh between the third-party and the end-user. Additionally, as stated above, this diagram represents all the major functions as discrete even though there may be integration of some functions as the industry grows and matures.

\subsection{Business Model Requirements}

The requirements for the utility controlled, third-party/customer owned business model are largely the same as for third-party/customer controlled model. The key difference is the regulatory regime, which would enable the utility to control significant assets on the customer side of meter. To the extent that utility control is not just for grid benefits but also to enable the utility to offer other services to the end-user, these regulatory changes will need to address the rules governing competition for providing these services. The main competitive issue is that the utility, as a monopoly, has an unfair advantage in its access to the customer. If the utility is allowed to access assets behind the meter for the benefit of the grid, but then is also allowed to leverage this access to offer customer- 
based services like backup power or energy management, other companies without such access might see this as unfair. To the extent that utilities were allowed to use the PV assets to provide value-added services to those customers who own them, the structure and pricing of these services must be determined in a transparent and equitable manner.

Since the asset is now controlled by a utility, the structure of the system-wide control architecture would be different. There is less of a need to be able to send the appropriate price or other signals to many owners. Instead, the control of the PV assets could be integrated into the utility's overall distribution network. For this, some key technologies include:

- Advanced communications, monitoring and metering, which allows for the utility to monitor, communicate with and control a large number of PV systems, and in a manner that best integrates with what the utility does on its side of the meter. Ideally, the network would be able to look at these PV assets in aggregate as opposed to discrete units;

- The ability to measure the value to the utility will be important because it will form the basis of the financial arrangement between the utility and the owner, and will affect tariff structures and cost levels;

- Energy storage to firm-up capacity and allow for dispatch of the system, and to enable services to end-users; and

- The ability to island the PV system, or the deployment of technologies that can lead to micro-grids, would enhance the value of the PV system to customers and the utility.

In these business models, the utility is more likely to provide incentives to site PV in constrained areas to maximize grid value. The utility also has more of an incentive to offer maintenance so that it can rely on the PV assets.

\subsection{Variations}

A number of variations on the basic business model described here are possible (see Table 4-8).

Table 4-8. Business Model Variations for Third-party/Customer Owned and Utility Controlled PV

\begin{tabular}{|l|l|}
\hline $\begin{array}{c}\text { Business Model } \\
\text { Variation }\end{array}$ & \multicolumn{1}{c|}{ Description } \\
\hline $\begin{array}{l}\text { Forward REC } \\
\text { purchases }\end{array}$ & $\begin{array}{l}\text { This is similar to the variation described above in Table 4-7; however, the } \\
\text { utility could offer financing to encourage PV deployment in critical areas, } \\
\text { perhaps offering preferential terms to customers in areas where the PV } \\
\text { would have the greatest value. }\end{array}$ \\
\hline Customer-focus & $\begin{array}{l}\text { This is similar to the variation describe above in Table 4-7 except that PV } \\
\text { could become part of a technology package offered to end-users by utilities, } \\
\text { as opposed to a third party. }\end{array}$ \\
\hline
\end{tabular}


Distribution utility as network services provider
This model is similar to the one described above in Table 4-7, except that the utility manages the asset on behalf of the customer/owner.

\subsection{Challenges}

Like the customer or third-party owned and controlled business models, the incremental value from active control of the PV assets may be too small to create new business models around these incremental value streams. Moreover, in these business models, the utility still does not control the timing or siting of PV capacity; therefore, it is difficult for the utility to incorporate deployment of PV into capital planning, as the ultimate decision to site remains out of their control. Nevertheless, as the utility gains experience in managing an ever-growing fleet of distributed PV, the utility should be able to gradually incorporate PV into its planning activities, which should increase its value. It may be important for the utility to enter into a long-term contract with the owner to enable it to include impacts of PV in system planning. As with the customer or third-party controlled business models, the utility could issue RFPs for customers to install PV and could include financing as part of the package. This would encourage siting in the best locations. The utility may also provide incentives to site in constrained areas to maximize grid value.

In unbundled markets, there is little way to address the potential impacts of widespread adoption of PV on retail electricity suppliers, wholesale generators, and transmission companies. However, these companies could take on the third-party ownership role, thereby mitigating some of the impacts. Still, in the case of very high PV deployment, there is potential for there to be stranded generation assets, in both vertically integrated and restructured markets.

In this structure, the dollars are expected to flow in both directions, and it is not entirely clear how this would work. The regulatory structure would need to make accommodations for lost revenues and the means to value PV attributes. Some activities may result in the flow of dollars to the utilities (e.g., for maintenance and power wheeling).

\subsubsection{Utility Owned and Utility Controlled PV Business Model}

\subsection{General Description}

This business model represents the greatest departure from today, as the utility reaches unequivocally behind the meter to own assets and provide a range of services to customers (see Figure 4-17). 


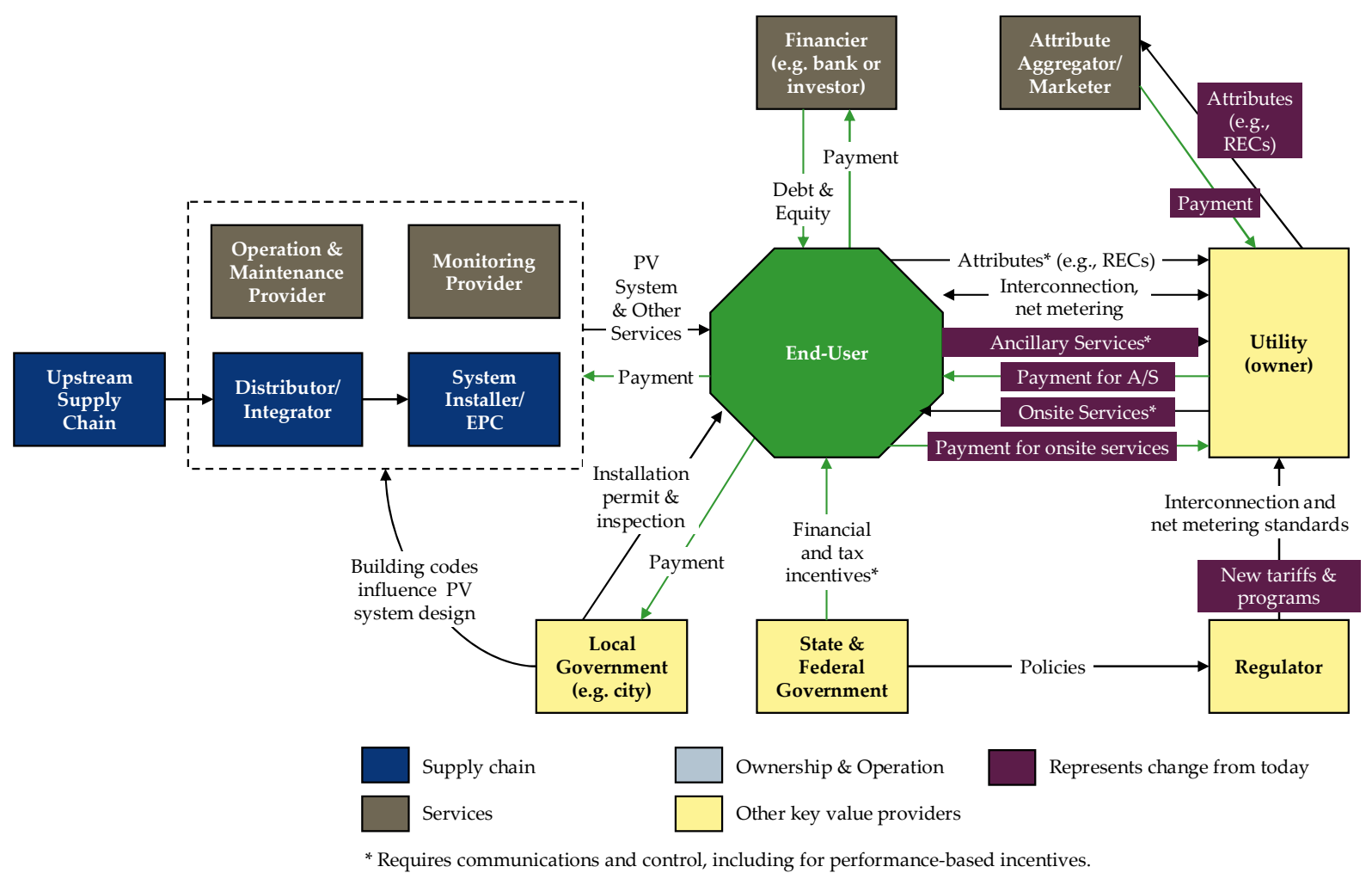

Figure 4-17. Utility Controlled and Owned Value Network

This model seeks to unlock greater distributed PV value by involving the utility directly in both ownership and control of the asset, and in monetization of the asset's value. This arrangement fits well with utility core competencies of asset ownership and operation. Given that PV is a capital-intensive asset, there is merit in putting such utility-owned assets in the rate-base.

With utility ownership, the S-RECs would go to the utility; therefore, this model may work particularly well in markets with S-RECs where the utility is the obligated party. The utility could also bundle the S-RECs into a green pricing program or sell them to other parties. Since S-REC values can be high, this model could be an attractive means of compliance with solar set-asides.

By allowing the utility the greatest control over the placement and subsequent operation of the asset, this model should generate the greatest overall value for the utility. Moreover, in this model, the utility can readily incorporate the grid benefits into its basic cost of service, as well as sell value-added services to the end-user. Of the three groups of business models, this one is the easiest model for the utility to incorporate deployment of PV into their capital planning, as the ultimate decision to install is in their control. However, the issue of competition will be a complication as the utility could have unfair advantage in providing value-added customer-oriented (vs. grid oriented) services that a third party may want to provide.

Like the other business models described above, regulatory and policy regimes will need to be changed significantly to allow the utility to reach so overtly behind the meter. To 
mitigate the potential scope of such regulatory and policy changes, the PV systems could be located on customer premises but placed on the utility side of the meter (this is similar to SDG\&E's placement of PV systems in its Sustainable Communities Program discussed in Section 4.2). In the past, states have prohibited utilities from owning and operating distributed energy resources (DER) because of concerns regarding market power. This concern will need to be addressed if and when PV systems become very inexpensive or otherwise attractive to utilities.

This business model will make sense in both vertically integrated and restructured markets, although the issue of generation asset ownership for distribution companies in restructured markets will need to be addressed.

This business model is expected to evolve more slowly than the others, given the additional regulatory changes required to permit utility control and ownership. Additionally, for utility control to have significant value to the utility, distributed PV has to exist on a sufficient scale, having a material impact on key values, such as the ability to offset generation, capacity, and T\&D investments.

\subsection{Business Model Requirements}

The business model requirements are largely the same here as above. The key difference is the regulatory regime which would need to address issues of asset ownership on the customer side of the meter. Competition for the provision of customer-side services, which are not subject to state regulation, would need to be addressed if the PV assets are used to provide value-added services to those particular customers that use them.

In a business model in which the PV assets are both controlled and owned by the utility, the structure of the system-wide control architecture would be different than in models in which the customer or a third party either controls or owns the assets. There would be no need to be able to send other signals to a large number of owners. Instead, the control of the PV assets would be integrated into the utility's overall distribution network.

Moreover, the deployment and use of PV systems would be more readily integrated into the utility's planning processes; PV systems would become extensions of the distribution grid. Thus, as PV is continually added, the utility would have the opportunity to make sure that the grid configuration remains optimal. This business model would also likely make it easier for utilities to justify investments required for grid reconfiguration, as this becomes necessary. For this model some key technologies include:

- Advanced communications, monitoring and metering, which allows for the utility to monitor, communicate with, and control a large number of PV systems, and in a manner that best integrates with what the utility does on its side of the meter. Ideally, the network would be able to look at these PV assets in aggregate as opposed to discrete units;

- The ability to measure the value to utilities will be perhaps less important than in other business models because the PV system is an extension of the distribution system and, therefore, simply part of the overall cost of service. Unless the utility offers products and services geared towards individual customers, such as backup, 
energy management, or different energy delivery pricing options, the arrangement between utility and the customer would be simple;

- Energy storage to firm up capacity and allow for dispatch of the system, and to enable services to end-users; and

- The ability to island the PV system, or the deployment of technologies that can lead to micro-grids, would enhance the value of the PV system to customers and the utility.

In these business models, the utility would identify the sites it wants to develop and work with those customers. If all that is needed is a site, a nominal fee could be charged for use of the space (like a lease for roof space). If value-added services are provided to the end user, a different arrangement will be required, based on the services provided. As the owner, the utility would almost surely provide the maintenance so that it can rely on the PV assets to the greatest extent possible.

\subsection{Variations}

A number of variations on the basic business model described here are possible (Table 4-9).

Table 4-9. Business Model Variations for Utility Owned and Controlled PV

\begin{tabular}{|l|l|}
\hline $\begin{array}{c}\text { Business Model } \\
\text { Variation }\end{array}$ & Similar to variation described above in Table 4-8. \\
\hline Customer-focus & $\begin{array}{l}\text { This model is similar to the one described above in Table 4-8 except that the } \\
\text { as Network } \\
\text { Services Provider } \\
\text { the benefit of the system as a whole. }\end{array}$ \\
\hline $\begin{array}{l}\text { System } \\
\text { Components }\end{array}$ & $\begin{array}{l}\text { Utility owns the inverter because it is the interface point between utility and } \\
\text { customer. It is the system component most likely to fail (the utility may have } \\
\text { made investments in the grid to accommodate PV system), and it is the } \\
\text { component that requires most on-going O\&M. Utility influence on the inverter } \\
\text { market could result in changes that improve integration with other } \\
\text { distribution automation and smart grid activities. }\end{array}$ \\
\hline Battery System & $\begin{array}{l}\text { Utility offers to add a battery back-up system, including automatic islanding } \\
\text { and resynchronization, to customer purchases of PV systems. They then } \\
\text { charge the customer for additional reliability service. Incremental system } \\
\text { cost would be rate based. }\end{array}$ \\
\hline $\begin{array}{l}\text { Battery System } \\
\text { and Controls }\end{array}$ & $\begin{array}{l}\text { In addition to the battery back-up system, the utility adds controls to the } \\
\text { system that allow it to tap into the system for additional value (e.g., peak } \\
\text { dispatchability, VAR support). }\end{array}$ \\
\hline $\begin{array}{l}\text { Battery System, } \\
\text { Controls and Plug- } \\
\text { in Hybrid Vehicles }\end{array}$ & $\begin{array}{l}\text { In addition to the battery system and controls above, the utility offers an } \\
\text { interface for plug-in hybrid vehicles. By adding the plug-in hybrid vehicle } \\
\text { load, the utility becomes a provider of transportation energy. }\end{array}$ \\
\hline Transfer & $\begin{array}{l}\text { Utility has agreement to purchase system from a third-party/customer once } \\
\text { tax benefits and accelerated depreciation are utilized (typically 5-6 years). } \\
\text { Utility is not the best party to act as a system developer or take advantage of } \\
\text { tax credits and other benefits at this time. Utility is well suited to take on }\end{array}$ \\
\hline
\end{tabular}




\begin{tabular}{|l|l|}
\hline & $\begin{array}{l}\text { long-term O\&M. System could be rate-based and would come at a } \\
\text { significant discount to the utility, with much of the useful life of the system } \\
\text { remaining. In addition, the utility could provide land or roof space to third- } \\
\text { parties, thus reducing the cost of the system. }\end{array}$ \\
\hline $\begin{array}{l}\text { Flat Price } \\
\text { Electricity }\end{array}$ & $\begin{array}{l}\text { Utility interactively manages energy consumption with the customer. } \\
\text { customer does not exceed certain price points. For example, a person on a } \\
\text { fixed income would be provided with a mobile device that supplies } \\
\text { information about the energy use. The goal is to not make it more } \\
\text { complicated than it is today }\end{array}$ \\
\hline Bundled Electricity \\
Services & $\begin{array}{l}\text { Manages electricity preference for customer, e.g., least cost, greenest. } \\
\text { Incorporates demand response, energy efficiency, PV (possibly as "loss } \\
\text { leader"), integration of plug-in hybrid electric vehicles. Takes advantage of } \\
\text { fact that price of PV-generated electricity does not change (like long-term } \\
\text { fuel contract) }\end{array}$ \\
\hline Bundled Energy & $\begin{array}{l}\text { Electricity (see above), but could also include provision of other energy } \\
\text { services, including heating fuel. Could include partnership with biofuels } \\
\text { Services }\end{array}$ \\
\hline
\end{tabular}




\subsection{Challenges}

Technological challenges would be not much different here than for other business models. The key challenges are likely to be regulatory, as these options require the greatest changes to the current regulatory structure. Regulations need to enable the utility to own customer-side assets, and, in the case of providing customer-oriented products and services, to fundamentally change the way utilities charge for service. The network may need to allow for distribution wheeling, which would entail significant reconfiguration. Note, however, that the issue of lost-revenues is more or less eliminated since the utility controls the output of the PV system and has the asset in the rate base.

In unbundled markets, there is little way to address the potential impacts of widespread adoption of PV on wholesale generators and transmission companies. Unlike in the previous business models, generation companies could not take on the third-party ownership role to help mitigate these impacts.

Tariff structures will need to incorporate rate-basing of PV assets into their structure and allow for the separation of charges for system-wide benefits and end-user benefits (where $\mathrm{PV}$ is sited and is part of service package). This could be a complex formula. In general, this option is tightly linked to how utility service offering will change in the future. PV could be the catalyst for this type of change. 
4-46 


\subsection{Conclusions and Recommendations for Future Research}

\subsection{Conclusions}

Currently, PV business models revolve around access to lower-cost financing, increasing the efficiency of the supply chain, and reducing hassles and complexity for the customer. These types of incremental improvements will occur naturally as 0 and $1^{s t}$ Generation business models continue to evolve.

Up until this point, there has been little reason to address system control or consider PV aggregation as an explicit policy matter, given the limited number of PV systems installed on the distribution grid. However, a time will come - in some areas of the country much sooner than others - when the sheer number of installed distributed PV systems becomes a material and operational concern—or opportunity—for utilities. Policy and regulatory considerations will then be paramount.

The most significant finding in this study to date is that the full benefits of an extensive distributed PV resource are not likely to be realized without some degree of utility control and ownership. The need to have active management and control of an increasingly large number of distributed PV systems implies that utilities will most likely become more involved in one way or another. As market penetration increases, distributed generation will reach a scale (i.e., generally greater than $100 \mathrm{MW}$ ) that could translate to significant value. For example, utility involvement could help optimize distributed PV assets by incorporating them into grid and generation planning. This is likely to reduce new peaking power requirements, distribution substation upgrades, and other system investments, thus unlocking latent value in the electric grid as a whole.

The results of the analyses performed in this series of DOE studies show that the real value of PV lies in its potential to offset generation, capacity, and T\&D investment. Such value greatly outweighs the value PV has for providing ancillary services on the distribution grid. Therefore, business model development will not be driven by the potential for ancillary grid services. It is the possibility that a large quantity of distributed PV systems will be installed that provides the greatest potential benefit to the nation's energy infrastructure, as these systems in aggregate could actually offset significant investment requirements in new generation, transmission, and distribution capacity.

Aside from the technological changes that will be required to accommodate a large capacity of PV on the grid, the organizational structure of today's utilities does not facilitate the adoption of the new business models discussed in this report. For example, current grid planning and operation practices do not explicitly take into account the potential value from $\mathrm{PV}$, and these functions are largely separate within utility organizations, which hampers inclusion of PV and other distributed resources in system planning. 


\subsection{Recommendations for Future Research}

\subsubsection{Role for DOE}

Through its efforts on Renewable Systems Interconnection, DOE is investing in understanding how technologies on the distribution grid can make significant contributions to meeting future electricity demands. Continued work on business models is a natural complement to this, as business models will facilitate how all of the technologies ultimately come together and transfer value to stakeholders. The future business models described in this report will require changes to industry structure, which implies risk for key stakeholders. DOE is in a position to work with key stakeholders to help mitigate some of the risk involved in pursing these new approaches.

To understand the potential real costs and benefits, promising future business models will need to be piloted at a sufficient scale, requiring significant time and investment. Today, the exact scope, duration, and scale of the business model pilots required is not clear because many issues still need to be addressed. It is critical that key stakeholders are engaged in understanding exactly what is holding back the development of these business models, because many of these companies and organizations are actively considering what the future will look like and how they will participate. In addition, explicit business model development should be coordinated with work on smart grid capabilities (e.g., distribution automation and advanced metering infrastructure), energy load management (e.g., demand response), and other distributed resource technologies. All of the business models discussed in this report will require integration with these other emerging technologies and capabilities, as well as PV. Because of the potential fundamental changes in regulation, technology, ownership, control, and grid management implied by the former, it is premature at this point for DOE to issue an RFP to pilot new business models. As an alternative to immediate pilot activity, we recommend the following threephase approach which is illustrated in Figure 5-1:

- Phase 1: Build the foundation

- Phase 2: Develop the scope

- Phase 3: Pilot business models and fund other supporting activities

As described below, work in Phases 1 and 2 involves studies and preparation for future business model pilots. These first two phases will likely take one and a half to two years. This additional time will allow the industry to mature and the pace of PV deployment to increase such that it more likely to achieve a scale sufficient to support business model pilots in Phase 3. 

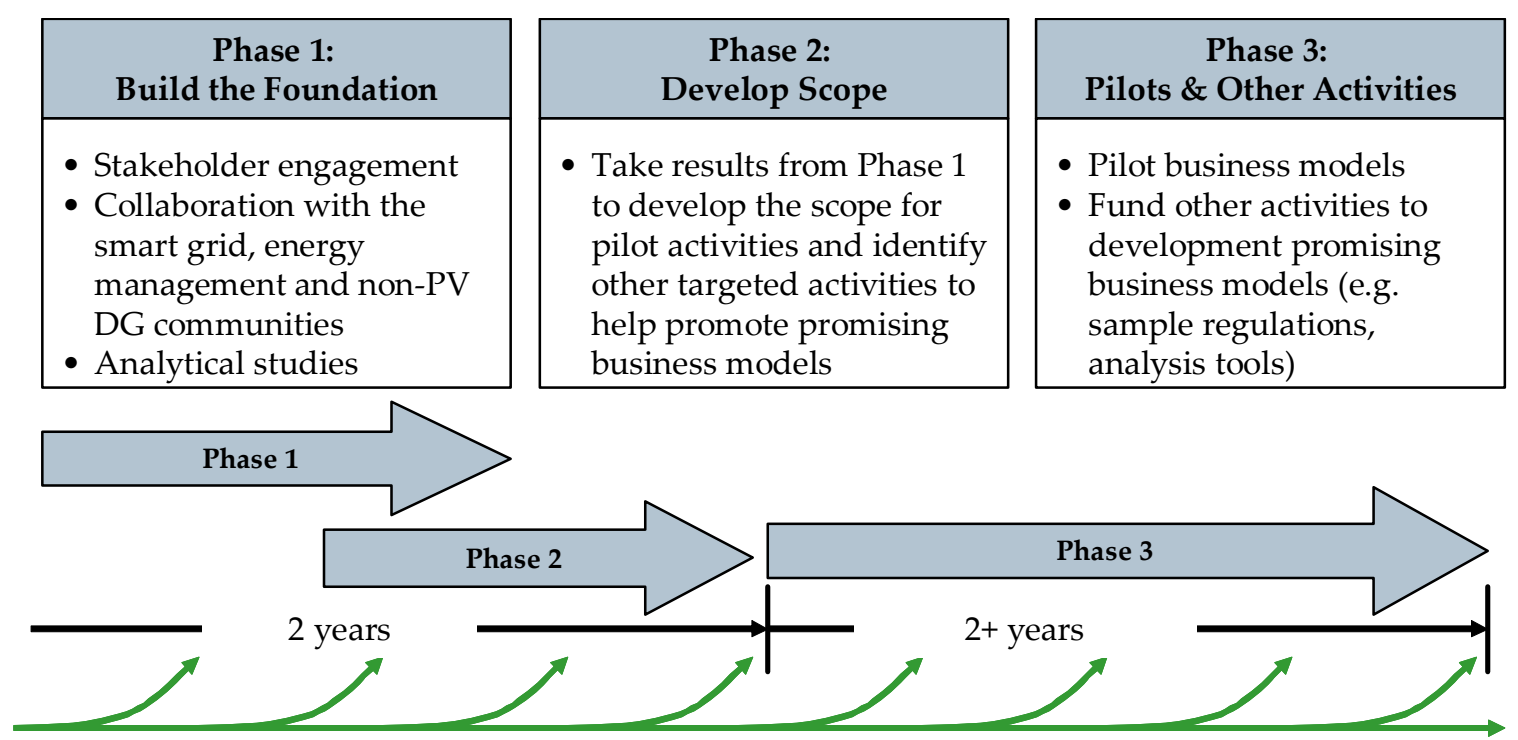

DOE efforts on Renewable System Interconnection will inform business model pilots

Figure 5-1. Three-phase approach to developing business model pilots

\subsubsection{Phase 1: Build the Foundation}

In Phase 1, DOE would develop a better understanding of how future business models would work, the barriers they will face, and the steps that will be required to overcome these barriers. Phase 1 involves three types of activities: stakeholder engagement; collaboration with the smart grid, energy management, and non-PV distributed generation communities; and analytical studies. The activities proposed for this phase would likely cost \$2-\$4 million. Cost share would be minimal as this work would primarily be studies, as opposed to development and deployment of technology.

\subsubsection{Key Stakeholder Input}

We suggest that DOE engage those stakeholders that are most critical to the success of these new business models. These are the companies likely to have the most significant financial stake in the outcome. The purpose would be to vet the business models developed in this paper and determine what is needed to move them forward. The key stakeholder groups we suggest engaging are utilities, regulators, and companies likely to provide equipment and services for these business models.

Utility leaders are already thinking about what the future will look like and what their role will be. This is especially true in states with aggressive climate change regulation in place. Strategic planners and other key decision makers from these utilities would likely have interest in participating in this type of activity with DOE.

Since it is largely the regulatory structure that defines utility business models, and new PV business models will require regulatory changes, it is critical to engage state and federal regulators to determine what types of actions they can take to facilitate promising business models. By increasing the understanding of the potential benefits business 
model options (like the ones presented in this report may have), the more likely it is that regulators will take stronger actions to support distributed generation, other technologies, and pricing structures that will be especially important in meeting key policy goals, such as climate change. Regulators may require guidance, tools, and information to better evaluate new PV business models. We suggest not just engaging regulators at the state level, but also engaging the National Association of Regulatory Utility Commissions (NARUC) and the Federal Energy Regulatory Commission (FERC), as both of these agencies have great influence over the decisions at the state-level. Regulators should be engaged in states that have demonstrated strong support for PV, and also in states with little regulatory support to date.

Finally, DOE should engage equipment and service providers who, like the utilities, are actively considering what the future distribution grid will look like and what product and services design features will be required to maximize value for their customers. Many of these companies have already developed future scenarios similar to the business models developed in this report, and their input on barriers and how DOE could help would be invaluable.

The type of questions these groups could address include:

- What are the key barriers restricting implementation of new business models?

- Do any of the new business models being considered have fatal flaws?

- How could the business models be modified or improved?

- What specific regulatory hurdles must be addresses?

- What could DOE or others do to encourage the most promising business models?

Various formats could be utilized for engaging stakeholders. We suggest that initially the different stakeholder groups meet separately so their specific concerns are thoroughly understood. Face-to-face meetings between a handful of high-level individuals would facilitate consensus building around priority issues. For regulators with limited budgets and time, DOE could consider a format that would not require additional expense for travel, such as a series of facilitated conference calls.

The current SEPA project, supported by DOE to engage utilities, might provide the answers to some of the questions listed above. In addition, DOE should review the results of the EPRI STAC work on utility incentives for distributed generation as it becomes available. $^{14}$

\subsubsection{Collaboration}

It is recognized that there are several other technologies faced with similar issues as PV, and there is much that can be learned about business model development by working both internally and externally with DOE to leverage what has and is being learned by organizations working with these technologies. This includes technologies that may be integrated with PV systems (i.e., as battery storage) and technologies that may operate

\footnotetext{
${ }^{14}$ Both the SEPA and EPRI projects are described briefly in 2.0.
} 
independently (i.e., fuel cells and combined heat and power (CHP)). There are also technologies such as Advanced Metering Infrastructure (AMI) and Smart Grid that are likely to prove necessary to facilitate the development of some of the business models that will be developed for PV. Many studies and programs have been developed to address similar issues for these other technologies and it will be important to leverage this work.

In preparation for developing the scope of the analytical studies and the subsequent pilot phase, we recommend that DOE develop an internal working group to establish internal collaboration between groups working on solar PV, smart grid, energy management, zero energy buildings, and non-PV distributed generation. Since the business models will require integrating PV with these emerging technologies and capabilities, collaboration across DOE's efforts will be critical. The focus of the collaboration would be to get input from these other groups on the business models developed in this paper and to identify opportunities for collaboration on the pilots

\subsubsection{Analytical Studies}

We recommend structuring several analytical studies that would serve to define more specifically the potential business and market structures to be tested during the business model pilots. For example, the business model structures outlined in this report will need to be developed in more detail to address how various regulatory structures will integrate with the business model(s) (e.g., municipal, competitive retail markets, vertically regulated utility markets) as cost, benefit, and value will flow to stakeholders differently depending on regulatory structure. For example, the types of questions that will need to be addressed include:

- How can distribution capacity value be determined for PV and allocated to the rate structure?

- Can distribution utilities obtain cost recovery for grid or customer sited PV?

- How will value be determined?

- How will generation capacity value be determined?

- How will generation capacity be allocated in the rate structure?

Another objective of the analytical studies is to develop a clear understanding of other key characteristics required to support successful implementation of each business model, including:

1. Technology bundles and performance characteristics (including the non-PV elements discussed above);

2. Utility organizational structure; and

3. Scale (e.g., amount of distributed generation required to make the model viable).

We suggest that DOE fund both generic and utility-specific studies. The generic studies would serve to advance understanding openly and could result in the development of tools for key stakeholder groups, such as utilities, regulators, policy makers, and equipment and service companies involved in providing energy services on the distribution grid. Generic studies could also be used to establish methodologies for evaluating the costs and benefits of business models such as the ones developed in this 
report. Finally, the results of generic studies could be used to raise awareness among key stakeholders.

In addition to the generic study, there is value in DOE funding utility-specific studies that would use information about specific system structures to evaluate business model costs and benefits. While DOE would have to determine to what level the specific utility information could be held confidential, these types of studies could have great value, especially to those utilities that have not begun to evaluate these types of business options.

Finally, both the generic and utility specific studies will benefit from the results of the Renewable System Interconnection studies and any additional DOE effort in this area. For example, additional research on the value of PV and likely characteristics of future PV systems will all be useful inputs to these studies.

We would expect the three activities in Phase 1 to result in:

- More robust descriptions of business model options;

- A specific list of prioritized items that would help promote promising business models; and

- Initial interest and input regarding the structure of a program to test pilot business models (feeds into Phase 2: Develop the scope).

\subsubsection{Phase 2: Develop the Scope}

In parallel with the activities identified in Phase 1, we recommend that DOE begin the process of working with the various stakeholders to develop the scope of desired pilot activities and identify other targeted activities that could help promote promising business models. Engagement of stakeholders in Phase 1 could be used as an opportunity to get input on desirable pilot activity and create interest. This work could be accomplished through a series of regional, topical, or stakeholder related DOE sponsored meetings and workshops, structured to solicit input from stakeholders on business model needs and barriers. Geographic regions could include the West Coast, Northeast, and Southeast. Topics may include things such as: "Barriers to Utility Ownership of PV" or "Creating Value for Utilities with Grid Sited PV."

At present, it is impossible to know what the most appropriate approach for piloting business models will be. While there is vast experience at DOE and elsewhere in piloting and demonstrating new technologies, government sponsored pilot programs to demonstrate business models are less common. In fact, it may be challenging to keep all stakeholders focused on the objective of piloting business models versus piloting or demonstrating technology.

Aspects of the pilot program scope that DOE should consider include:

- Scale: What scale is required to test the business model? 
- Geographic Location: What locations will provide the best pilots and results? For example, areas where high penetration of PV already exists or where very little activity has occurred?

- Cost share: What will DOE want to cost share? At what level? Who are other likely funders?

- Timing: How will the need for regulatory approval impact the timing?

- Participants: Are most likely utility participants' distribution companies and load serving entities? What equipment and service companies might want to team with utilities?

- Organization: Given the potentially high cost of piloting business models, could utilities and companies form a consortium to test a business model in one service territory?

In addition to the pilots, DOE will want to consider funding other targeted activities that address the barriers and needs identified in Phase 1. These types of activities may include such things as:

- Model tariffs and standards

- Sample regulatory structures approved by NARUC

- Spreadsheet based tools for comparing and evaluating business model impacts

By working with the stakeholders early-on, DOE will be able to begin to understand the potential types of groups that are likely to propose business model pilots. Through a series of regional, topical, or stakeholder-specific workshops, DOE can begin to solicit interest in bidding and begin to engage in discussions with groups regarding the types of proposals they are likely to be able to assemble. Input gathered during these meetings and workshops would be used to structure the RFP in a way that would increase the likelihood of obtaining desirable proposals for Phase 3.

\subsubsection{Phase 3: Pilot Business Models and Other Supporting Activities}

The importance of running pilots is to demonstrate the value that can be created through new business models and show that they are possible. For most of the future business models described in this paper, significant changes to industry structure will be required, including changes to grid hardware, grid operation, utility organization, and utility regulation. To help prepare the industry and to smooth the road with regulators, demonstrations of the real costs and benefits are essential. In addition, pilots will serve to identify barriers and challenges that need to be addressed. This type of support from DOE could help avert a slow down in PV market expansion due to resistance from utilities and regulators to permit high penetration of $\mathrm{PV}$ on distribution systems.

As has been discussed in this report, development of effective PV business models will require other new technologies and systems. These may include battery storage, microgrid system architectures, AMI, smart grid technologies, and integration with energy management systems. Business model pilots should be structured as cross cutting activities that benefit a broader set of technologies and stakeholders. Additionally, pilots should address a broad set of industry stakeholders; for example, municipal utility 
organizations, distribution companies, vertically integrated utilities, energy service companies, equipment providers, and regulators. As the pilot programs are structured, it will be important to assess how the various stakeholders and ancillary technologies are included.

Since DOE has made a great effort to understand what the future will look like and appears to be pushing forward on the technical aspects of the distribution grid of the future, it seems logical that DOE should help test the business models that are most likely to unlock the value technological advances can deliver. 


\subsection{References}

Dicum, Gregory. "Green Solar Gets Practical”. 1/25/2006, (c) 2006 Hearst

Communications, Inc. http://sfgate.com/cgi-bin/article.cgi?f=/g/a/2006/01/25/gree.DTL

FPL Group press release: FPL Group Plans to Boost U.S. Solar Energy Production. JUNO BEACH, Fla., Sep 26, 2007).

"Lennar to Include Solar Electric Systems in All New San Francisco Bay Area Homes", 03/01/2007, http://www.buildingonline.com/news/viewnews.pl?id=5849

Moore, Geoffrey. Crossing the Chasm, Harper Business, 1991.

Navigant Consulting PV Service Program. August 2007.

Navigant Consulting, The Value of PV, developed as part of the Renewable Systems Integration Studies funded by DOE 2007.

Solar Shares presentation at Solar Power 2007 Conference Pre-Conference Workshop on Utility Business Models. Long Beach, California. September, 2007.

"Xcel Energy announces the largest photovoltaic central solar power plant in the United States”. Xcel Energy News Release: Sept 25, 2006. 
6-10 


\subsection{Appendix: Case Studies of Current Business Models}

\subsection{End-user Owner/Residential Retrofit: Borrego Solar}

Borrego Solar Systems, Inc. has more than 25 years of experience in the solar installation industry, specializing in commercial, residential, and public-sector turnkey, gridconnected systems. The case study (Table 7-1) focuses specifically on Borrego's end-user, residential retrofit business model, which fits into the category of Hassle-Free, as described in Table 4-2.

Table 7-1. Case Study: Borrego Solar

\begin{tabular}{|c|c|}
\hline Owner/Application & User/Residential Retrofit \\
\hline \multicolumn{2}{|l|}{ Company Profile } \\
\hline $\begin{array}{l}\text { Business Model } \\
\text { Variation }\end{array}$ & - Hassle-free \\
\hline Company & - Borrego Solar Systems, Inc. \\
\hline Consumer Profile & $\begin{array}{l}\text { - Demographic focus: Borrego's customers tend to be: } \\
\text { homeowners/professionals, upper-middle class, living in } 1,500-2,000 \\
\text { sq-ft homes, and have } \$ 100-\$ 150 / \text { month electric bills. } \\
\text { - Geographic focus: The San Francisco Bay area and Southern } \\
\text { California, with a recent push into the NE region of the United States. } \\
\text { - Typical system size: } 5 \mathrm{kWp} \\
\text { - Total system cost: Ranges from } \$ 25 \mathrm{~K} \text { to } \$ 100 \mathrm{~K} \text {, or } \$ 8.00 \text { - } \\
\quad \$ 10.00 / \mathrm{Wp} \text {. } \\
\text { - Net cost: Borrego cites an example of a } \$ 30,400 \text { installation } \\
\text { translating to a net cost to owner of approximately } \$ 19,000 \text { after all } \\
\text { possible rebates. }\end{array}$ \\
\hline $\begin{array}{l}\text { System } \\
\text { Characteristics }\end{array}$ & $\begin{array}{l}\text { - Economic breakeven point: 6-12 years } \\
\text { - System technology: In its new market in the Northeast, Borrego is } \\
\text { partnering with Evergreen Solar, the manufacturer that uses String } \\
\text { Ribbon wafer technology. However, the company relies primarily on } \\
\text { crystalline modules, along with grid-connected inverters from SMA } \\
\text { and Xantrex. The company uses Web-enabled monitoring from SMA; } \\
\text { it does not do battery back-up systems. }\end{array}$ \\
\hline Marketing Process & $\begin{array}{l}\text { - Reputation: Borrego has } 27 \text { years of experience in the California } \\
\text { market, and one of the strongest reputations for turnkey solar } \\
\text { systems. } \\
\text { - Partnerships: Borrego builds relationships with home builders, solar } \\
\text { suppliers, and government to develop new business. }\end{array}$ \\
\hline $\begin{array}{l}\text { Sources of } \\
\text { Financing }\end{array}$ & $\begin{array}{l}\text { - Cost reduction from incentives: State rebates cover } 20-30 \% \text { of total } \\
\text { installation cost ( } \$ 2.20 / \mathrm{Wpac}) \text {, along with } \$ 2000 \text { in federal tax } \\
\text { incentives. } \\
\text { - Other: Borrego encourages customers to make use of secured loans, } \\
\text { such as home equity loans (or lines of credit), which typically have } \\
\text { the best terms and lowest interest rates. }\end{array}$ \\
\hline
\end{tabular}

${ }^{15}$ Dicum, Gregory. “Green Solar Gets Practical”.1/25/2006, (C) 2006 Hearst Communications, Inc. http://sfgate.com/cgi-bin/article.cgi?f=/g/a/2006/01/25/gree.DTL 


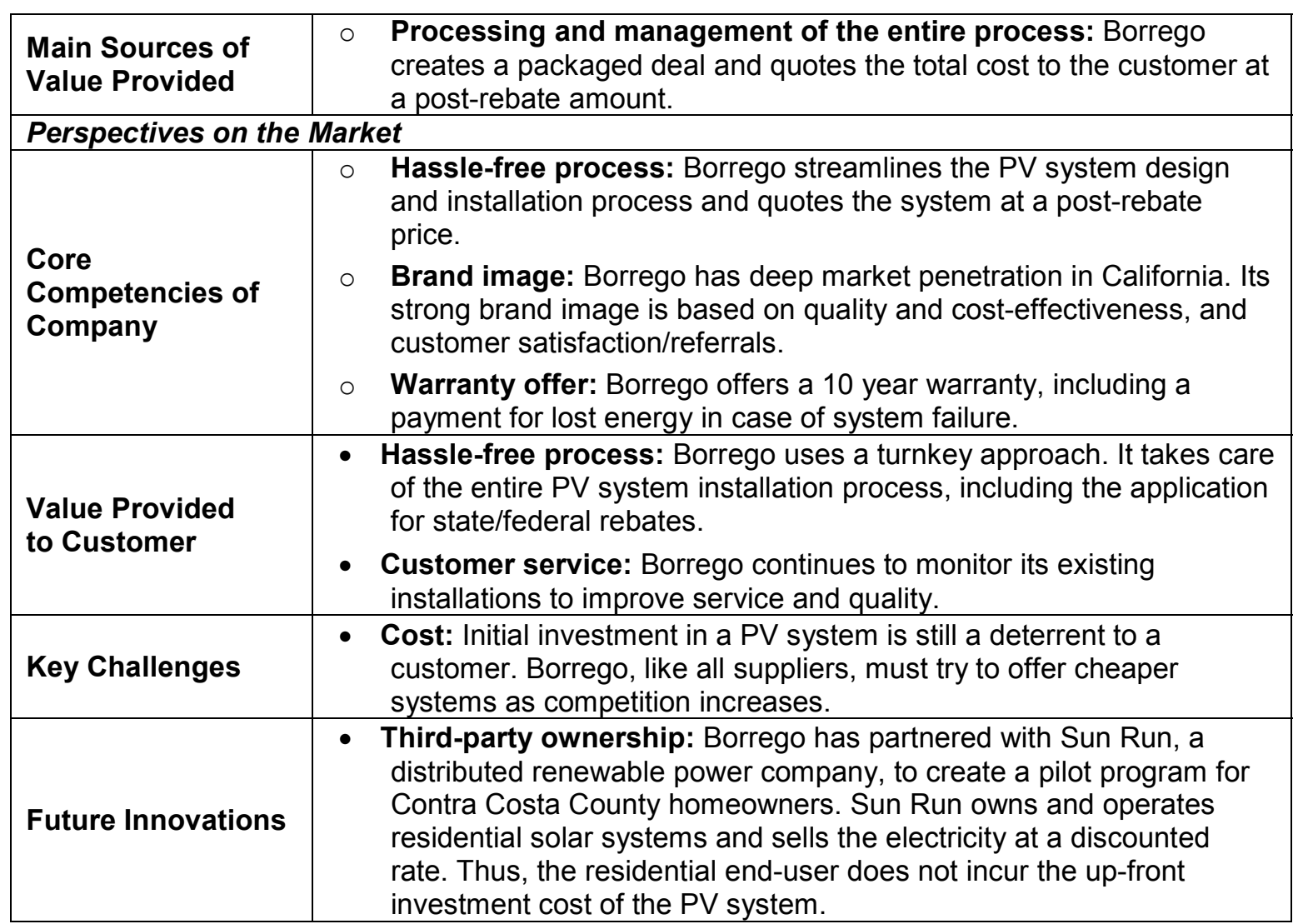

Though the end-user owner/residential retrofit market is now the slowest growing of the U.S. grid-tied market segments examined in this report, Borrego's new third-party ownership innovation with Sun Run, as described in Table 7-1 above, opens a door for potential customers who are interested in solar but do not want, or cannot afford, to incur the installation cost. Borrego has set the stage for the future development of third-party ownership and operation in the end-user owner/residential retrofit market. 


\subsection{End-user Owner/Residential New Construction: Old Country Roofing}

Old Country Roofing (OCR) is a market leader in the end-user owner, residential new construction market. It was chosen as a case study because few similar business models currently exist, and competition in this market is expected to grow as builders and homeowners begin to understand the delicate relationship between roof integrity and solar roof installations. Table 7-2 highlights the key takeaways of OCR's business model.

Table 7-2. Case Study: Old Country Roofing

\begin{tabular}{|c|c|}
\hline Owner/Application & User/Residential Retrofit \\
\hline \multicolumn{2}{|l|}{ Company Profile } \\
\hline $\begin{array}{l}\text { Business Model } \\
\text { Variation }\end{array}$ & - Roofing company \\
\hline Company & - Old Country Roofing (OCR) \\
\hline Consumer Profile & $\begin{array}{l}\text { - Demographic focus: OCR serves early adopters in this new solar } \\
\text { roofing market. Home builders are increasingly incorporating OCR's } \\
\text { solar roofing into multi-unit community-home projects. } \\
\text { - Geographic focus: Primarily Central and Northern California, but } \\
\text { OCR recently opened an office in Nevada. }\end{array}$ \\
\hline $\begin{array}{l}\text { System } \\
\text { Characteristics }\end{array}$ & $\begin{array}{l}\text { - Typical system size: } 1.5 \text { - } 3.0 \mathrm{kWdc} \text {; average is approximately } 2.4 \text { - } \\
2.5 \mathrm{kWdc} \\
\text { - Total system cost: A PV roof is } 4-5 \text { times the cost of a regular roof: } \\
\$ 8-9 / \mathrm{kWdc} \text { or } \$ 20-25 \mathrm{k} \text { for the PV and } \$ 6-8 \mathrm{k} \text { for the normal roof. } \\
\text { - Economic rational: OCR tells customers to analyze breakeven from } \\
\text { a cash flow or ROI point of view (i.e., look at incremental cash cost } \\
\text { for a solar roof built into the mortgage price vs. the incremental cash } \\
\text { savings on energy). With the PV cost built into a mortgage, a } \\
\text { payback can be seen on the first utility bill. For example, if the } \\
\text { additional cost of the PV system is } \$ 110 / \text { month, but the PV system is } \\
\text { designed to lower the electric bill } \$ 120 / \text { month, that means "the house } \\
\text { is paying the owner } \$ 10 / \text { month." } \\
\text { - System technology: OCR's primary supply partner is BP. It } \\
\text { frequently uses BP's Solar EnergyTile }{ }^{\mathrm{TM}} \text { roof integrated solar } \\
\text { modules and BP Solar Integra }{ }^{\circledR} \text { low profile solar modules. }\end{array}$ \\
\hline Marketing Process & $\begin{array}{l}\text { - Three primary initiatives: 1) Sales teams for existing customer } \\
\text { relations with homebuilders; 2) Participation in San Francisco PCBC } \\
\text { trade show, which serves residential builders and their project teams } \\
\text { and has up to } 25,000 \text { attendees; and 3) Free workshops to educate } \\
\text { builders on solar roofing. }\end{array}$ \\
\hline $\begin{array}{l}\text { Sources of } \\
\text { Financing }\end{array}$ & $\begin{array}{l}\text { Cost reduction from incentives: } \$ 2.60 / \mathrm{Wpac} \text { from California New } \\
\text { Home Solar program and a } \$ 2000 \text { federal tax credit for residential } \\
\text { systems. } \\
\text { - Home mortgage: Homeowners roll the installation cost into their } \\
\text { home mortgage. }\end{array}$ \\
\hline $\begin{array}{l}\text { Main Sources of } \\
\text { Value Provided }\end{array}$ & $\begin{array}{l}\text { System installation: OCR was the first contractor in the country to } \\
\text { offer a comprehensive turnkey solution that includes both roofing and } \\
\text { solar. }\end{array}$ \\
\hline
\end{tabular}




\begin{tabular}{|c|c|}
\hline \multicolumn{2}{|c|}{ Perspectives on the Market } \\
\hline \multirow{3}{*}{$\begin{array}{l}\text { Core } \\
\text { Competencies of } \\
\text { Company }\end{array}$} & $\begin{array}{l}\text { Knowledge of roofing: OCR takes responsibility for the entire roof, } \\
\text { not just the solar panel installation. They understand the importance } \\
\text { of integrating the two to ensure roof integrity. }\end{array}$ \\
\hline & $\begin{array}{l}\text { Economies of scale: OCR is the leading roofing company in } \\
\text { northern CA; other roofing companies have not been able to scale. }\end{array}$ \\
\hline & $\begin{array}{l}\text { Brand image: OCR is the first roofing contractor in the country to be } \\
\text { certified "National Housing Quality Certified Trade Contractor" by the } \\
\text { National Association of Home Builders. }\end{array}$ \\
\hline \multirow[b]{2}{*}{$\begin{array}{l}\text { Value Provided } \\
\text { to Customer }\end{array}$} & $\begin{array}{l}\text { Hassle-free process: OCR provides an entire-package: design, } \\
\text { installation, warranty, and customer service. }\end{array}$ \\
\hline & $\begin{array}{l}\text { - Customer service: OCR guarantees customer satisfaction, which } \\
\text { was a "pinnacle decision maker" for Tim Lewis Communities in } \\
\text { Sacramento. }{ }^{16}\end{array}$ \\
\hline \multirow{2}{*}{ Key Challenges } & $\begin{array}{l}\text { - Consumer awareness: Builders do not fully understand the solar } \\
\text { roofing concept. They are still uneducated and may not choose OCR } \\
\text { over a stand-alone solar installation company because they do not } \\
\text { understand the value of roof integration. }\end{array}$ \\
\hline & $\begin{array}{l}\text { - Investment rational: Most customers want to know how many years } \\
\text { it will take to recoup their investment. OCR is shifting the focus to a } \\
\text { cash flow analysis to show that a PV system generate positive cash } \\
\text { flows starting in the first month. }\end{array}$ \\
\hline
\end{tabular}

OCR has recognized how little developers and builders know about the impact of solar installations on rooftop integrity. While the company is holding workshops to educate its customers in California, solar roofing is taking off across the country, and OCR recommends that the government take a role in supporting the education of solar roofing. OCR anticipated a potential new business service in 5-10 years, when existing homes with solar installations begin to have structural problems with their roofs.

\footnotetext{
${ }^{16}$ Sacramento homebuilder, Tim Lewis Communities, announced plans to build several of its new communities to exceed state standards for energy efficiency, certifying them as a California Green Builder. Three communities will offer Solar Living Homes and were available for pre-sale beginning in late March and mid-April 2007. http://www.sustainablehomemag.com/CDA/Articles/Feature_Article/BNP_GUID_95-2006_A_10000000000000144641
} 


\subsection{Third-party Owner/Commercial Retrofit: SunPower}

SunPower has more than 10 years of experience in providing roof, ground, and elevatedparking solar systems to commercial customers. The company most recently signed a 10year PPA-to-Own with Macy's Department Stores to provide a hassle-free energy solution to 15 of its stores in California. Table 7-3 provides the details of SunPower's Basic/PPA-to-Own business model.

Table 7-3. Case Study: SunPower

\begin{tabular}{|c|c|}
\hline Owner/Application & Third-party Owner/Commercial Retrofit \\
\hline \multicolumn{2}{|l|}{ Company Profile } \\
\hline $\begin{array}{l}\text { Business Model } \\
\text { Variation }\end{array}$ & - PPA-to-Own \\
\hline Company & - SunPower Corporation Systems \\
\hline Consumer Profile & $\begin{array}{l}\text { Demographic focus: Clients include over } 15 \text { Fortune } 500 \text { global } \\
\text { corporations. Positive public relations and cost reduction motivate } \\
\text { these customers. } \\
\text { - Geographic focus: SunPower Systems has a global focus with } \\
\text { revenue divided between its U.S., Europe, and Asia operations. }\end{array}$ \\
\hline $\begin{array}{l}\text { System } \\
\text { Characteristics }\end{array}$ & $\begin{array}{l}\text { - Typical system size: } 1 \mathrm{MW} \\
\text { - Total system cost: System Cost is not published by SunPower as it } \\
\text { can vary by location, solar irradiance, the purchase type, and many } \\
\text { other factors. } \\
\text { - Payback period: } 5 \text { to } 15 \text { years }\end{array}$ \\
\hline Marketing Process & $\begin{array}{l}\text { Focus: Large accounts through direct marketing via sales } \\
\text { representatives. } \\
\text { Modes of outreach: A variety of media and outlets are used, } \\
\text { including: print and web collateral, active public and media relations, } \\
\text { print and radio advertising, industry and customer alliances, and } \\
\text { participation in renewable energy industry and regional trade } \\
\text { conferences and events. }\end{array}$ \\
\hline $\begin{array}{l}\text { Sources of } \\
\text { Financing }\end{array}$ & $\begin{array}{l}\text { PPA: The customer signs a 10-year (minimum) fixed price } \\
\text { agreement with SunPower. The customer does not own the PV } \\
\text { system, but simply purchases the energy it generates. } \\
\text { - Investment partners: GE Finance, Morgan Stanley, MMA } \\
\text { Renewable Ventures, others. }\end{array}$ \\
\hline $\begin{array}{l}\text { Main Sources of } \\
\text { Value Provided }\end{array}$ & $\begin{array}{l}\text { Processing and management of entire process: The customer } \\
\text { simply buys the solar kWh produced at a fixed-rate for at least } 10 \\
\text { years. SunPower pays for and deploys the solar system, and the } \\
\text { customer hosts the system. }\end{array}$ \\
\hline
\end{tabular}




\begin{tabular}{|c|c|}
\hline \multicolumn{2}{|c|}{ Perspectives on the Market } \\
\hline $\begin{array}{l}\text { Core } \\
\text { Competencies of } \\
\text { Company }\end{array}$ & $\begin{array}{ll}\circ & \text { Technology: Best-in-class non-penetrating rooftop mounting and } \\
\text { single-axis tracking systems are key competitive advantages. } \\
\circ \text { Project support: R\&D programs and large-scale project experience. }\end{array}$ \\
\hline $\begin{array}{l}\text { Value Provided } \\
\text { to Customer }\end{array}$ & $\begin{array}{l}\text { - One-stop shop: SunPower has access for those customers that want } \\
\text { a PV system without the responsibility. Commercial customers are } \\
\text { able to simply buy the solar power a PV system generates. }\end{array}$ \\
\hline Key Challenges & $\begin{array}{l}\text { - Extending and enhancing U.S. federal and state incentives for } \\
\text { commercial solar power purchases. } \\
\text { - Reducing the cost of solar power systems by } 50 \% \text { by } 2012 \text { in } \\
\text { order to compete with retail electric rates. } \\
\text { - Generating a broader awareness for the benefits of solar. }\end{array}$ \\
\hline Future innovations & $\begin{array}{l}\text { - System cost reduction: The supply of solar cells and components } \\
\text { for panels and systems will rise and new technology will improve the } \\
\text { way in which solar is delivered and installed, all contributing to a } \\
\text { decrease in the cost of solar systems. }\end{array}$ \\
\hline
\end{tabular}

SunPower and its competitors are finding success with this business model primarily in California and the Northeast, where state financial incentives are the highest. If other states follow suit, the cost of electricity versus solar rises, or solar system costs come down, big box stores throughout the remainder of the country may become future customers. 


\subsection{Third-party owner/Grid-Sited: SunEdison}

Table 7-4. Case Study: SunEdison

\begin{tabular}{|c|c|}
\hline Owner/Application & Third-party Owner/Grid-sited \\
\hline \multicolumn{2}{|l|}{ Company Profile } \\
\hline $\begin{array}{l}\text { Business Model } \\
\text { Variation }\end{array}$ & - Basic \\
\hline Company & - SunEdison \\
\hline Consumer Profile & $\begin{array}{l}\text { Demographic focus: Typical customers of grid-sited applications } \\
\text { (e.g., utilities) have the following characteristics: they are subject to } \\
\text { renewable portfolio standard targets; have transmission and } \\
\text { distribution systems that are facing specific areas with peak load } \\
\text { congestion; are under increasing pressure from the public and } \\
\text { customers to adopt renewable energy solutions; and have an energy } \\
\text { generation portfolio with high exposure to fossil fuel volatility. } \\
\text { - Geographic focus: SunEdison has a presence through the United } \\
\text { States and Canada. The majority of its business comes from CA, NJ } \\
\text { and CT, however, the company's business is growing in CO, AZ, NV, } \\
\mathrm{HI} \text { and RI. }\end{array}$ \\
\hline $\begin{array}{l}\text { System } \\
\text { Characteristics }\end{array}$ & $\begin{array}{l}\text { Typical system size: }>1 \mathrm{MWp} \\
\text { - Total system price: Averages } \$ 6.20 / \mathrm{Wp} \text { dc } \\
\text { - System technology: SunEdison is one of the few solar services } \\
\text { providers that are technology agnostic. Most solar service providers } \\
\text { in the utility space have "proprietary technology" from trackers, to } \\
\text { concentrators, to low-efficiency thin-film technologies. SunEdison's } \\
\text { innovation is around bringing in-house construction capabilities and } \\
\text { fully optimized financing to reducing the non-technology costs of the } \\
\text { projects. Matched with its technology approach, SunEdison serves } \\
\text { as a partner to the utility company-promoting the most appropriate } \\
\text { technology for the defined application. }\end{array}$ \\
\hline Marketing Process & $\begin{array}{l}\text { - Focus: On potential utility accounts through direct marketing via } \\
\text { sales representatives. }\end{array}$ \\
\hline $\begin{array}{l}\text { Sources of } \\
\text { Financing }\end{array}$ & $\begin{array}{l}\text { PPA: A 20-year, fixed price agreement is settled between SunEdison } \\
\text { and the customer. The rate is dependent on the available subsidies. } \\
\text { The Alamosa project came in around } 20 \text { cents per kWh. } \\
\text { - Investment partners: Goldman Sachs, MissionPoint Capital } \\
\text { Partners, Allco, and one individual investor. } \\
\text { - System cost reduction based on incentives: } 30 \% \text { Investment Tax } \\
\text { Credit, 5-year accelerated depreciation of equipment, and any } \\
\text { applicable state rebate. }\end{array}$ \\
\hline $\begin{array}{l}\text { Main Sources of } \\
\text { Value Provided }\end{array}$ & $\begin{array}{l}\text { Processing and management of entire process: SunEdison } \\
\text { handles everything from conducting the on-site assessment of needs } \\
\text { and solar potential to selecting the appropriate technology and } \\
\text { maintaining the finished PV system over its lifetime. SunEdison runs } \\
\text { and manages their own trained and qualified crews, enabling them to } \\
\text { maintain quality and accountability. }\end{array}$ \\
\hline
\end{tabular}




\begin{tabular}{|c|c|}
\hline \multicolumn{2}{|c|}{ Perspectives on the Market } \\
\hline $\begin{array}{l}\text { Core } \\
\text { Competencies of } \\
\text { Company }\end{array}$ & $\begin{array}{l}\circ \text { Access to a wide range of technology choices and commercial real } \\
\text { estate. } \\
\circ \text { Financial engineering skills (access to low cost of capital). } \\
\circ \text { A strong track record. }\end{array}$ \\
\hline $\begin{array}{l}\text { Value Provided } \\
\text { to Customer }\end{array}$ & $\begin{array}{l}\text { One-stop shop: No capital investment is required for the solar } \\
\text { system host facility. SunEdison secures financing and takes } \\
\text { responsibility for the entire PV system. The customer gets the benefit } \\
\text { of a secure fixed energy rate. }\end{array}$ \\
\hline Key Challenges & $\begin{array}{l}\text { - Lowering inherent business risk given policy that could significantly } \\
\text { increase or decrease the cost of solar to the customer. } \\
\text { - Evaluating the many new technologies coming on the market each } \\
\text { year to meet the needs of our customers. } \\
\text { - Cost effectively maintaining the solar assets to achieve } 99 \%+\text { system } \\
\text { availability. }\end{array}$ \\
\hline Future innovations & $\begin{array}{l}\text { - New technologies: SunEdison may expand its model to long-term } \\
\text { energy efficiency and DSM technologies with 7+ year paybacks, but } \\
\text { currently it is focused on solar products. } \\
\text { - International growth: SunEdison recently appointed a new executive } \\
\text { to oversee SunEdison's solar deployment strategies in markets } \\
\text { outside of the United States. }\end{array}$ \\
\hline
\end{tabular}

In Mid 2006, SunEdison and Xcel Energy signed an agreement for an 8 MW PV plant in Colorado in response to the state's new RPS requirement. The plant will use both flatplate solar panels and concentrating photovoltaic units, representing 6.8 MW and 1.2 MW, respectively. ${ }^{17}$ This system was completed in November 2007 and now represents the largest utility scale Solar PV project in the US. Xcel Energy is one of a hand-full of utilities across the US that has taken the initiative to pursue this sort of project to meets its RPS but is hopefully setting the standard for others to follow.

\footnotetext{
17 "Xcel Energy announces the largest photovoltaic central solar power plant in the United States." Xcel Energy News Release: Sept 25, 2006.
} 


\section{REPORT DOCUMENTATION PAGE}

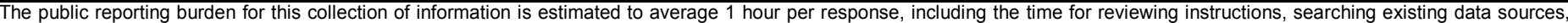

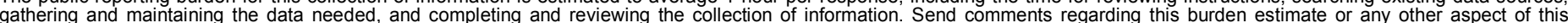

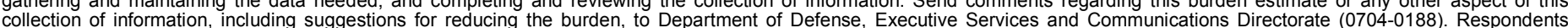

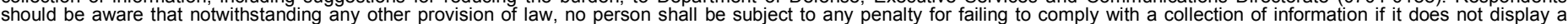

should be aware that notwithstanding

PLEASE DO NOT RETURN YOUR FORM TO THE ABOVE ORGANIZATION.

\begin{tabular}{l|l|l|l} 
1. REPORT DATE $(D D-M M-Y Y Y Y)$ & 2. REPORT TYPE & 3. DATES COVERED (FrOm - TO)
\end{tabular}

February 2008

Subcontract report

4. TITLE AND SUBTITLE

Photovoltaics Business Models

5a. CONTRACT NUMBER

DE-AC36-99-G010337

5b. GRANT NUMBER

5c. PROGRAM ELEMENT NUMBER

6. AUTHOR(S)

L. Frantzis, S. Graham, R. Katofsky, and H. Sawyer

5d. PROJECT NUMBER

NREL/SR-581-42304

5e. TASK NUMBER

PVB7.6401

5f. WORK UNIT NUMBER
7. PERFORMING ORGANIZATION NAME(S) AND ADDRESS(ES)

Navigant Consulting Inc.

77 South Bedford St.

Burlington, MA 01803

9. SPONSORING/MONITORING AGENCY NAME(S) AND ADDRESS(ES)

National Renewable Energy Laboratory

1617 Cole Blvd.

Golden, CO 80401-3393
8. PERFORMING ORGANIZATION REPORT NUMBER

NREL/SR-581-42304

12. DISTRIBUTION AVAILABILITY STATEMENT

National Technical Information Service

U.S. Department of Commerce

5285 Port Royal Road

Springfield, VA 22161

13. SUPPLEMENTARY NOTES

NREL Technical Monitor: Robert Margolis

14. ABSTRACT (Maximum 200 Words)

This report summarizes work to better understand the structure of future photovoltaics business models and the research, development, and demonstration required to support their deployment.

\section{SUBJECT TERMS}

photovoltaics; PV; business models; utility business model; renewable systems interconnection; Navigant Consulting; National Renewable Energy Laboratory; NREL

16. SECURITY CLASSIFICATION OF:
\begin{tabular}{|l|l|l|}
\hline a. REPORT & b. ABSTRACT & c. THIS PAGE \\
Unclassified & Unclassified & Unclassified \\
& & \\
\hline
\end{tabular}

\begin{tabular}{|c|c|}
\hline $\begin{array}{l}\text { 17. LIMITATION } \\
\text { OF ABSTRACT }\end{array}$ & $\begin{array}{l}\text { 18. NUMBER } \\
\text { OF PAGES }\end{array}$ \\
\hline UL & \\
\hline
\end{tabular}

19a. NAME OF RESPONSIBLE PERSON

19b. TELEPHONE NUMBER (Include area code) 